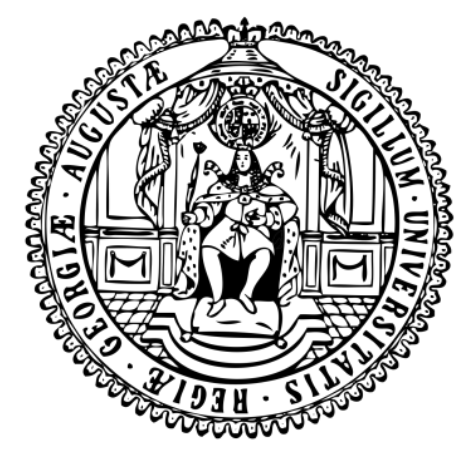

\title{
Effect of land use on soil fertility and carbon sequestration
}

\author{
Dissertation \\ to obtain the Doctoral Degree of Philosophy (Ph.D.) \\ within the doctoral degree program \\ at the Faculty of Forest Sciences and Forest Ecology, \\ Georg-August University of Göttingen, Germany
}

\author{
Presented by \\ Menuka Maharjan \\ Kathmandu, Nepal
}

Göttingen, March 2018 


\section{Members of the thesis committee (supervisors):}

1. Prof. Dr. Michaela Dippold, Department of Biogeochemistry of Agroecosystems, University of Goettingen, Germany

2. PD. Dr. Evgenia Blagodatskaya, Soil Sciences of Temperate and Boreal Ecosystems, University of Goettingen, Germany

3. Prof. Helena Kahiluoto, Lappeenranta University of Technology, Lappeenranta, Finland 


\section{Table of Contents}

\section{Contents}

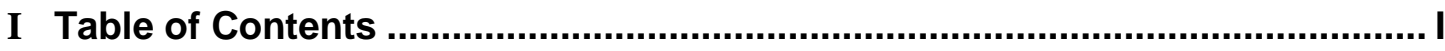

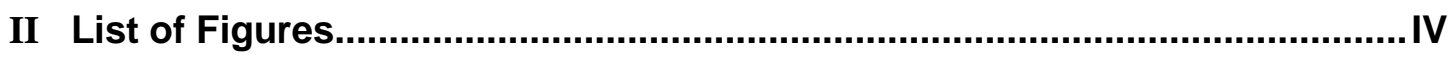

III List of Tables........................................................................................... VII

IV Abbreviations .................................................................................... VIII

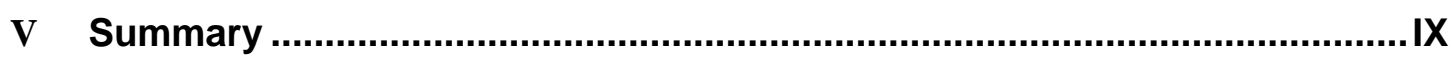

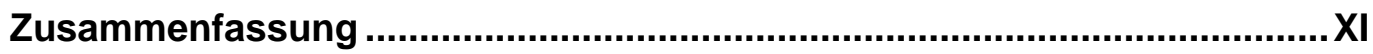

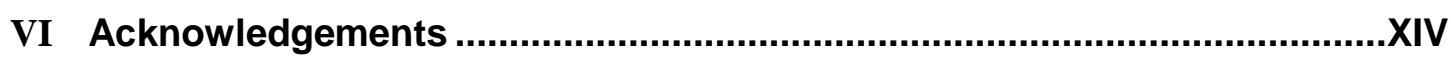

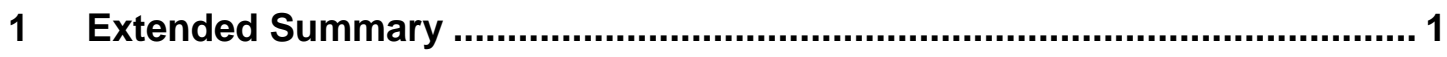

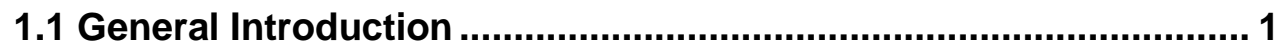

1.1.1 Land-use change ................................................... 1

1.1.2 Agricultural intesification and its conequences ................... 1

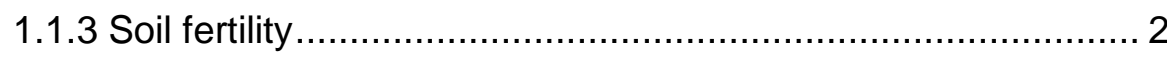

1.1.4 Soil organic carbon, priming effect and global carbon cycle ... 3

1.2 Objectives ...................................................................................... 4

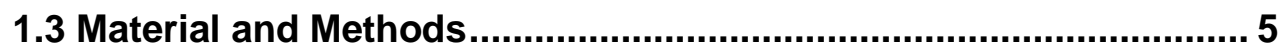

1.3.1 Description of the study site and soil sampling ................... 5

1.3.2 Experimental design, method and analysis-study $1 \ldots \ldots \ldots \ldots \ldots . .7$

1.3.3 Experimental design, method and analysis-study $2 \ldots \ldots \ldots \ldots . . .8$

1.3.4 Experimental design, method and analysis-study $3 \ldots \ldots \ldots \ldots 9$

1.3.5 Experimental design, method and analysis-study $4 \ldots \ldots \ldots \ldots 10$

1.4 Main results and discussion.................................................. 11

1.4.1 Soil and microbial properties ......................................... 11

1.4.2 Land use control on P availability .................................. 13

1.4.3 Microbial respiratory response to substrates addition ........... 15

1.4.4 Road to sustainability .................................................. 18 


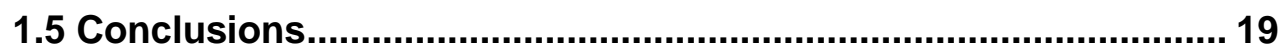

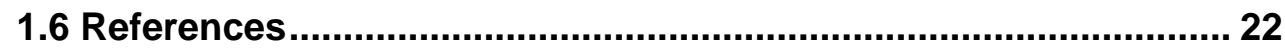

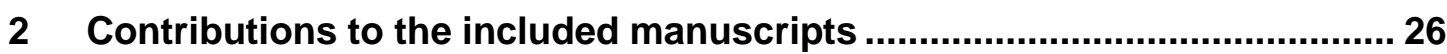

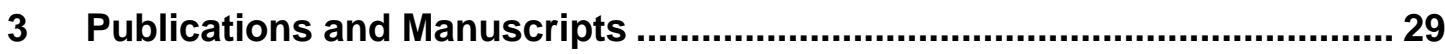

3.1 Study 1: Effect of land use and management practices on microbial biomass and enzyme activities in subtropical top-and sub-soils...... 29

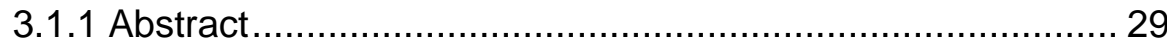

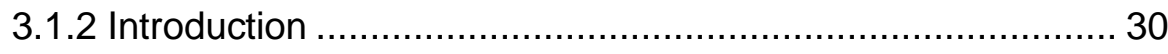

3.1.3 Materials and Methods .................................................... 31

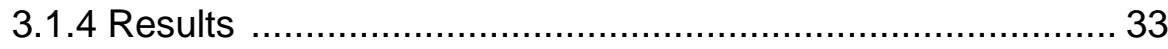

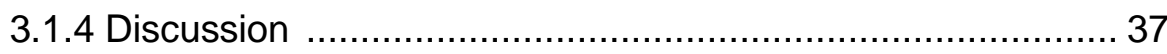

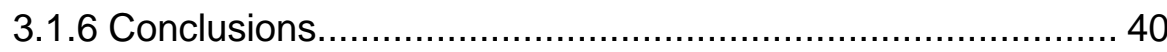

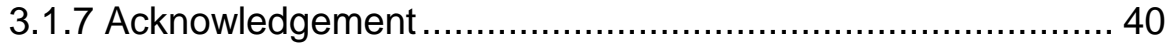

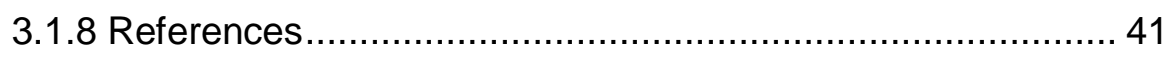

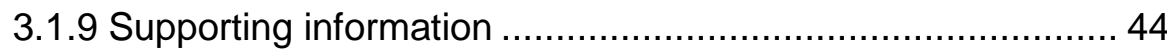

3.2 Study 2: Phosphorus fractions in subtropical soils depending on

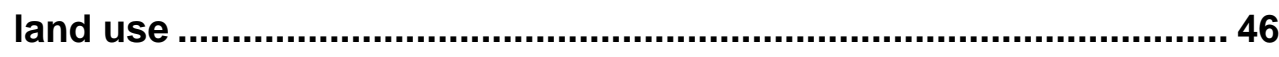

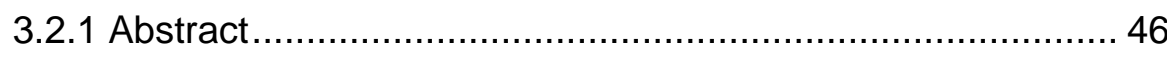

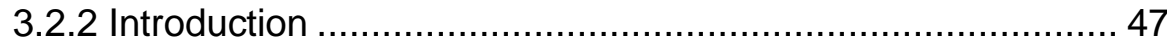

3.2.3 Material and methods........................................................ 49

3.2.4 Results ....................................................................... 52

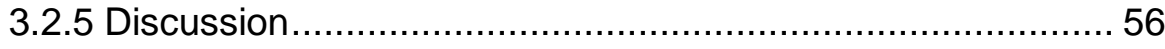

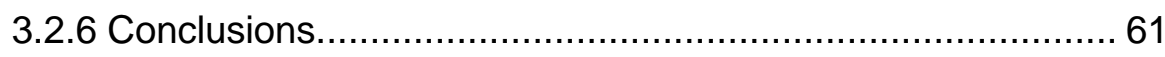

3.2.7 Acknowledgement ............................................................... 61

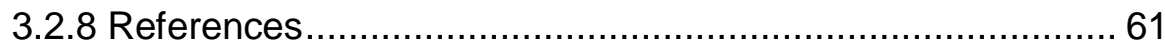

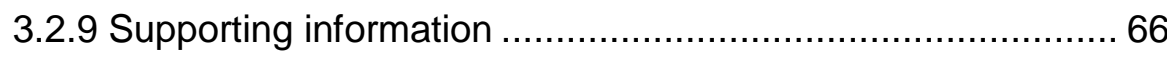

3.3 Study 3: Nutrient availability regulates soil organic matter decompositon depending on land use ............................................67

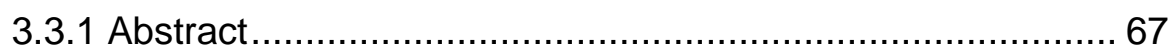


3.3.2 Introduction 68

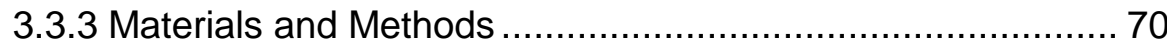

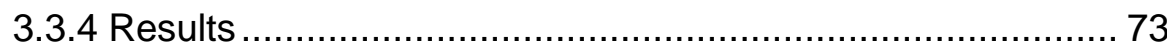

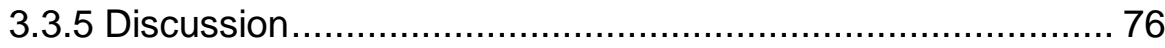

3.3.6 Conclusions................................................................ 79

3.3.7 Acknowledgements ..................................................... 79

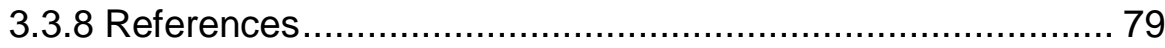

3.3.9 Supporting information................................. 82

3.4 Study 4: Microbial necromass as a source of priming reglulated by micorbial growth strategies...............................................83

3.4.1 Abstract ............................................................... 83

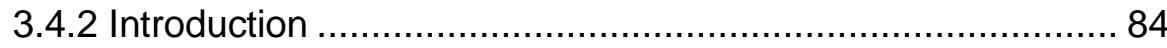

3.4.3 Methodolgy .......................................................... 86

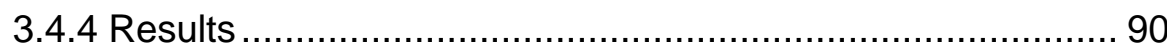

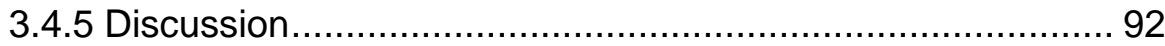

3.4.6 Conclusion .............................................................. 94

3.4.7 Acknowledgements .................................................. 95

3.4.8 References................................................................ 95

4 Abstracts of additional studies.............................................................. 97

4.1 Study 5: Spatio-temporal patterns of enzyme activities after manure application reflect mechanims of niche differentiation between plant and microorganims 97

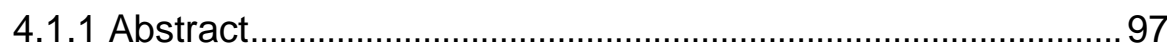

4.2 Study 6: Effects of rhizosphere wettability on microbial biomass, enzyme activities and localization ...................................................... 99

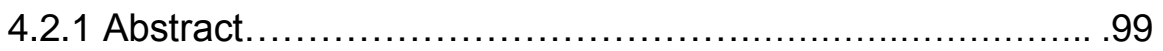

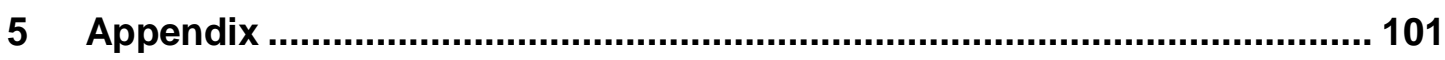

5.1 Curriculum vitae .......................................................................... 101

5.2 Declarations ................................................................................ 103 


\section{List of Figures}

Extended Summary:........................................................................

Figure S1 Location of Nepal in Asia (top) and map of Chitwan district, Nepal (bottom)

Figure S2 Three land-use systems i.e. fores, organic and convetional farming in Chitwan district,Nepal. .7

Figure S3 Total $\mathrm{C}, \mathrm{N}$ and microbial $\mathrm{C}$ and $\mathrm{N}$ depending on land use and depth. Value represnts means $\pm S E(n=3)$.

Figure S4 The effect of land use on carbon nitrogn contnet in soil along with enyzme activities under different land use system .13

Figure S5 Total content of organic and inorganic $\mathrm{P}\left(\mathrm{mg} \mathrm{P} \mathrm{kg}^{-1}\right)$ (top) and $\mathrm{P}$ stocks (kg $\mathrm{P}$ $\mathrm{ha}^{-1}$ ) (bottom) depending on land use.Values represent means \pm SE $(n=4)$. Means followed by different letters within the same depth differ significantly $(p<0.05)$.

Figure S6 Ratio of soil carbon to organic phosphorus and acid phosphatase activity ( $\mathrm{nmol} \mathrm{g}^{-}$ ${ }^{1}$ soil $\left.h^{-1}\right)$ depending on land use. Values represent means $\pm \operatorname{SE}(n=4)$. Means followed by different letters within the same depth differ significantly $(p<$ 0.05) 14

Figure S7 The effect of land use on soil P. Colors: green=easily-available phosphorus, yellow=moderately-available phosphorus, brown= non-available phosphorus. Olive color upward arrow represents factors contribution for increasing different fractions of phosphorus in soil under organic farming. Light blue and light pink downward arrows indicates factors responsible for decreasing different fractions of phosphorus in soil under conventional farming and forest, respectively. The double circle arrows (peach color) indicate the phosphate activity. Color intensity of horizontal arrow i.e. light to dark purple represents the lower to higher status of phosphorus stock in soil under forest conventional farming and organic farming. Litter, crop residue and organic fertilizers are dominant factor controlling the soil phosphorus stock in forest, conventional farming and organic farming, respectively. Red line $\quad(-)$ shows $P$ losses after land-use change. .15

Figure S8 Cumulative priming over 45 days of incubation period and cumulative $\mathrm{CO}_{2}$ emission at 45 days in soil under organic farming, conventional farming, forest. Add dotted line indication PE and letters of significance to the bars. Values are means \pm standard error $(n=4)$ 
Figure S9 Microbial biomass derived from soil organic matter and from added glucose in soil under organic farming (a), conventional farming (b) and forest (c) at the end of incubation. Control, $\mathrm{C}, \mathrm{C}+\mathrm{N}, \mathrm{C}+\mathrm{P}$, and $\mathrm{C}+\mathrm{N}+\mathrm{P}$ in the figure represent the addition of water, glucose only, glucose + nitrogen, glucose + phosphorus, glucose + nitrogen + phosphorus, respectively.Values are means \pm standard $\operatorname{error}(n=4)$

Figure S10 Maximum specific growth rate and lag time in soil under different land use system. Values are means \pm standard error $(n=3)$.

Figure S11 Synthesis of the main results. Effect of land use on soil fertility, and carbon sequestration. SOM-soil organic matter,C-Sequ-carbon sequestration.

Study 1:

Figure 1 Total $\mathrm{C}, \mathrm{N}$ and microbial $\mathrm{C}$ and $\mathrm{N}$ depending on land use and depth. Value represtns means $\pm S E(n=3)$.

Figure 2 Activities of C-cycle enzymes: $\beta$-glucosidase, cellobiohydrolase and xylanase depending on land use and depth. Values represent means $\pm S E(n=3)$. Enzyme activities are expressed in $\mathrm{nmol} \mathrm{g}^{-1}$ soil $\mathrm{h}^{-1}$ ).

Figure 3 Activities of $\mathrm{N}$-cycle enzymes: chitinase, leucine aminopeptidase and tyrosine aminopeptidase depending on land use and depth. Values represent means $\pm S E(n=3)$. Enzyme activities are expressed in $\mathrm{nmol} \mathrm{g}^{-1}$ soil $^{-1}$

Figure 4 Activities of $\mathrm{P}$ and $\mathrm{S}$-cycle enzymes: acid phosphatase and sulfatase depending on land use and depth. Values represent means $\pm S E(n=3)$. Enzyme activities are expressed in $\mathrm{nmol} \mathrm{g}^{-1}$ soil $^{-1}$

Figure 5 Conceptual diagram representing the effect of land use on carbon and nitrogen content in soil along with enzyme activities.

Figure S1 Relationship between the activities of $\beta$-glucosidase, cellobiohydrolase, xylanase, acid phosphatase and microbial biomass $C$. Microbial biomass $C$ is expressed in $\mu g \mathrm{Cg}^{-1}$

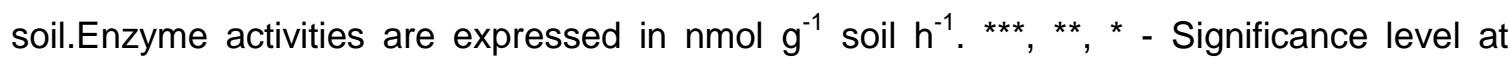
$\mathrm{p}<0.001,<0.01,<0.05$, respectively. NS - not significant.

Figure S2 Relationship between the activities of chitinase, leucine aminopeptidase, tyrosine aminopeptidase and microbial biomass $\mathrm{N}$, and sulfatase with microbial biomass $\mathrm{C}$. Microbial biomass $\mathrm{N}$ and $\mathrm{C}$ are expressed in $\mu \mathrm{g} \mathrm{N} \mathrm{g}{ }^{-1}$ soil and $\mu \mathrm{C} \mathrm{g}^{-1}$ soil, respectively. Enzyme

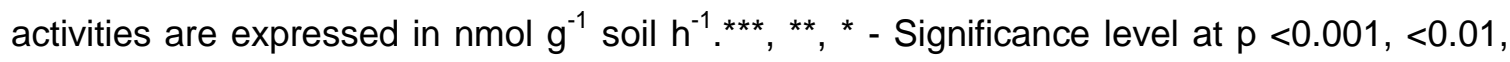
$<0.05$, respectively. NS - not significant.

Study 2: 
Figure 1 Microbial biomass carbon ( $\mathrm{mg} \mathrm{C} \mathrm{g}^{-1}$ ) (Maharjan et al. 2017, modified) and Phosphorus ( $\mathrm{mg} \mathrm{F} \mathrm{k}^{-1}$ ) depending on land use. Values represent means $\pm S E(n=4)$ Means followed by different letters within the same depth differ significantly $(p<$ 0.05).

Figure 2 Total content of organic and inorganic $\mathrm{P}\left(\mathrm{mg} \mathrm{P} \mathrm{kg}^{-1}\right)$ (top) and $\mathrm{P}$ stocks $\left(\mathrm{kg} \mathrm{P} \mathrm{ha}^{-1}\right)$ (bottom) depending on land use. Values represent means $\pm \operatorname{SE}(n=4)$. 54

Figure 3 Inorganic and organic soil phosphorus fractions ( $\mathrm{mg} \mathrm{P} \mathrm{kg-1)}$ depending on land use. Values represent means $\pm S E(n=4)$. Means followed by different letters within the same depth differ significantly $(p<0.05)$.

Figure 4 Ratio of soil carbon to organic phosphorus and acid phosphatase activity (nmol g ${ }^{-1}$ soil $\left.h^{-1}\right)$ depending on land use. Values represent means $\pm S E(n=4)$. Means followed by different letters within the same depth differ significantly $(p<0.05)$.

Figure 5 Conceptual diagram representing the effects of land use on soil phosphorus. Colors: green=easily-available phosphorus, yellow=moderately-available phosphorus, brown= non-available phosphorus. Olive color upward arrow represents factors contribution for increasing different fractions of phosphorus in soil under organic farming. Light blue and light pink downward arrows indicates factors responsible for decreasing different fractions of phosphorus in soil under conventional farming and forest, respectively. The double circle arrows (peach color) indicate the phosphate activity. Color intensity of horizontal arrow i.e. light to dark purple represents the lower to higher status of phosphorus stock in soil under forest conventional farming and organic farming. Litter, crop residue and organic fertilizers are dominant factor controlling the soil phosphorus stock in forest, conventional farming and organic farming, respectively. Red line (-) shows $\mathrm{P}$ losses after land-use change.

Figure S1 Sequential fractionation of phosphorus $(P)$ in soil (Hedley et al., 1982 modified by Tiessen and Moir, 1993). The $P$ fractions were classified into three groups: 1) easilyavailable $\mathrm{P}$ included $\mathrm{NaHCO}_{3}$-extractable $\mathrm{P}$ and microbial $\mathrm{P} ; 2$ ) moderately-available $\mathrm{P}$ included $\mathrm{P}$ extracted from $0.5 \mathrm{M} \mathrm{NaOH}$ and 3) non-available $\mathrm{P}$ included $\mathrm{P}$ extracted by $1 \mathrm{M}$ $\mathrm{HCl}$ (Tiessen et al., 1984). Dashed line (-) shows microbial biomass $P$ was measured based on the method of Kouno et al., (1995) and Cheesman et al., (2010) slightly modified by Yevdokimov and Blagodatskaya (2014)..... 66

Study 3:

Figure 1 Rate of $\mathrm{CO}_{2}$ emission in soil under organic farming (a), conventional farming (b), and forest (c). Control, $\mathrm{C}, \mathrm{C}+\mathrm{N}, \mathrm{C}+\mathrm{P}$, and $\mathrm{C}+\mathrm{N}+\mathrm{P}$ in the figure represent the addition of water, glucose only, glucose + nitrogen, glucose + phosphorus, glucose + nitrogen + phosphorus, respectively. Values are means \pm standard error $(n=4) \ldots$ 
Figure 2 Cumulative $\mathrm{CO}_{2}$ derived from soil organic matter (blue) and from added glucose (blank) in soil under organic farming (a), conventional farming (b), and forest (c) at the end of incubation. Control, $\mathrm{C}, \mathrm{C}+\mathrm{N}, \mathrm{C}+\mathrm{P}$, and $\mathrm{C}+\mathrm{N}+\mathrm{P}$ in the figure represent the addition of water, glucose only, glucose + nitrogen, glucose + phosphorus, glucose + nitrogen + phosphorus, respectively. Values are means \pm standard error $(n=4)$. Capital letters indicate the significance difference among treatments for SOM derived cumulative $\mathrm{CO}_{2}$ emission. Small letters indicate the significance difference among treatments for Glucose derived cumulative $\mathrm{CO}_{2}$ emission. .74

Figure 3 Cumulative primed $\mathrm{CO}_{2}$ emission in soil under organic farming (a), conventional farming, (b) and forest (c). $\mathrm{C}, \mathrm{C}+\mathrm{N}, \mathrm{C}+\mathrm{P}$, and $\mathrm{C}+\mathrm{N}+\mathrm{P}$ in the figure represent the addition of glucose only, glucose + nitrogen, glucose + phosphorus, glucose + nitrogen + phosphorus, respectively. Values are means \pm standard error $(n=4)$. .75

Figure 4 Microbial biomass derived from soil organic matter and from added glucose in soil under organic farming (a), conventional farming, (b) and forest (c) at the end of incubation. Control, $\mathrm{C}, \mathrm{C}+\mathrm{N}, \mathrm{C}+\mathrm{P}$, and $\mathrm{C}+\mathrm{N}+\mathrm{P}$ in the figure represent the addition of water, glucose only, glucose + nitrogen, glucose + phosphorus, glucose + nitrogen + phosphorus,

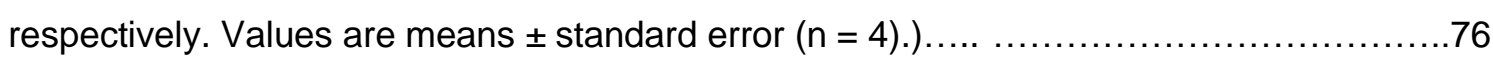

Figure $\mathbf{S 1}$ Cumulative ${ }^{14} \mathrm{C}$-glucose decomposition in soil under organic farming (a), conventional farming (b), and forest (c). $\mathrm{C}, \mathrm{C}+\mathrm{N}, \mathrm{C}+\mathrm{P}$, and $\mathrm{C}+\mathrm{N}+\mathrm{P}$ in the figure represent the addition of glucose only, glucose + nitrogen, glucose + phosphorus, glucose + nitrogen + phosphorus, respectively. Values are means \pm standard error $(n=4)$.

Study 4:

Figure 1 Cumulative priming over 45 days of incubation period and cumulative $\mathrm{CO}_{2}$ emission at 45 days in soil under organic farming, conventional farming, and forest. Values are means \pm standard error $(n=4) \ldots$

Figure 2 Microbial biomass at 45 days in soil under organic farming, conventional farming, and forest. Values are means \pm standard error $(n=4)$

Figure 3 Substrate-induced respiration rates, maximum specific growth rate and lag time in soil under different land use system. Values are means \pm standard error $(n=3)$......

Figure 4 Conceptual diagrams representing the three types of life strategies corresponding to three types land use system (Panikov, 2010). PE-priming effect and MOmicroorganism. 


\section{List of Tables}

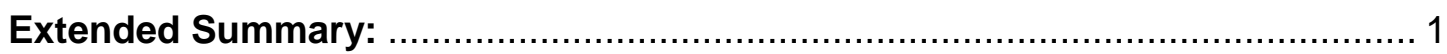

Table S1 Description of land use and soil properties (Ap/Ah horizon) .............................6

Table S2 Summary of the materials and methods used in study 1 ................................. 8

Table S3 Summary of the materials and methods used in study 2 .................................

Table S4 Summary of the materials and methods used in study 3 ................................10

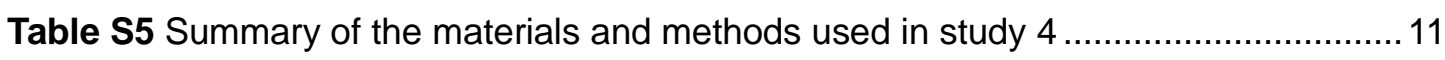

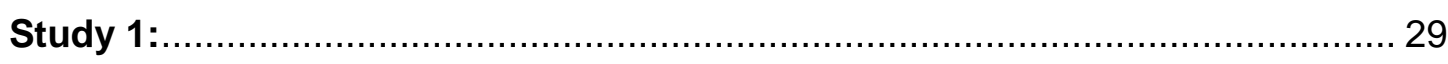

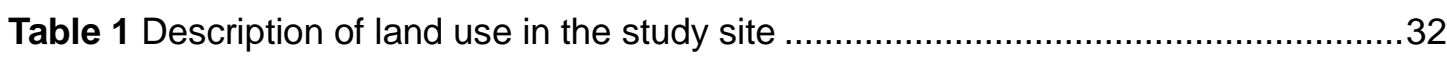

Table S1 Description of the substrates for estimation of enzyme activities. ....................44

Study 2:

Table 1 Description of land use and soil properties (Ap/Ah horizon) ............................49

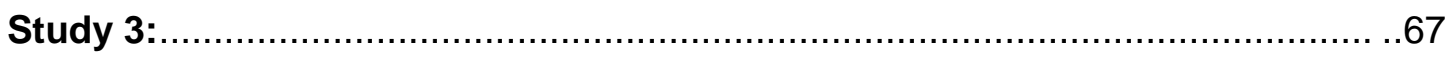

Table 1 Description of chemical properties of soil under different land use systems........70

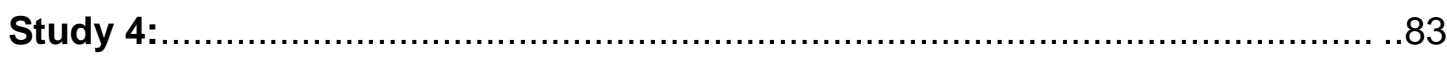

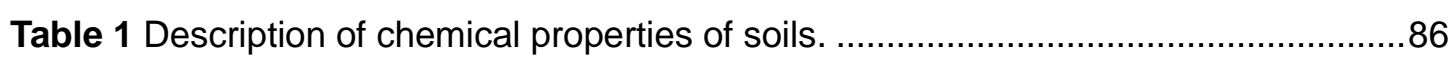




\section{Abbreviations}

$\begin{array}{ll}\text { AEM } & \text { Anion exchange membrane } \\ \text { C } & \text { Carbon } \\ \text { DPM } & \text { Disintegration per minute } \\ \text { MBC } & \text { Microbial biomass carbon } \\ \text { MBN } & \text { Microbial biomass nitrogen } \\ \text { MBP } & \text { Microbial biomass phosphorus } \\ \mathrm{N} & \text { Nitrogen } \\ \mathrm{P} & \text { Phosphorus } \\ \mathrm{PE} & \text { Priming effect } \\ \mathrm{Pi} & \text { Inorganic phosphorus } \\ \mathrm{PO} & \text { Organic phosphorus } \\ \mathrm{P}_{\mathrm{NaHCO}} & \text { Easily available phosphorus extracted by } \mathrm{NaHCO} \\ \mathrm{P}_{\mathrm{NaOH}} & \text { Moderately-available phosphorus extracted by } \mathrm{NaOH} \\ \mathrm{P}_{\mathrm{HCl}} & \text { Non-available phosphorus extracted by } \mathrm{HCl} \\ \mathrm{SOC} & \text { Soil organic carbon } \\ \mathrm{SOM} & \text { Soil organic matter } \\ \mathrm{TP} & \text { Total phosphorus } \\ \text { WHC } & \text { Water holding capacity }\end{array}$




\section{Summary}

Land-use change, particularly the conversion of natural forest to agriculture to sustain the growing global population, has severe environmental impacts, including emission of greenhouse gases, diminished biodiversity, and altered soil functions. Agriculture intensification further reduces the fertility of soil, negatively impacting the sustainability of agriculture production and increasing the loss of soil organic carbon, which contributes to climate change. This thesis aims to assess the impacts of land-use systems on soil fertility and carbon sequestration.

Due to its agricultural based economy, land is the most valuable resource in Nepal. The study site "Chitwan district" lies in the Terai region, a plain in southern Nepal. Known as the grain house of Nepal, the Terai region covers $17 \%$ of the country's total land area. Forests are dominated by Shorea robusta Roth and possess high economic value and biological diversity. People are extremely dependent on forests for timber and non-timber forest products. After eradication of malaria in the 1950s, the government introduced a resettlement and migration scheme from the Middle Mountain region to different parts of the Terai region, resulting in, massive deforestation to support cultivation and new settlements which continues to this day. Hence, the forest cover has been continuously declining. Agricultural intensification through conventional farming practices is also being implemented to feed the growing population.

Soil samples were collected from three major land-use systems: forest, organic and conventional farming in Chitwan district, Nepal. The content of soil organic carbon (C), total nitrogen $(\mathrm{N})$, microbial biomass $(\mathrm{C}$ and $\mathrm{N}$ ) and six enzyme activities ( $\beta$-glucosidase, cellobiohydrolase, chitinase, leucine aminopeptidase, tyrosine aminopeptidase, and sulfatase) were significantly higher under organic farming than conventional farming and forest, especially in topsoil layer. However, acid phosphatase activity was significantly higher (up to 6 fold) under conventional farming than forest and organic farming. The pools varying in $P$ availability were estimated by $P$ sequential fractionation approach (Hedley, 1982). The concentration of microbial biomass $P$, easily-available $P$, moderately available $\mathrm{P}$, non-available $\mathrm{P}$, and total $\mathrm{P}$ were much higher under organic farming than conventional farming and forest. However, the ratio of $C$ to organic $P$ was greater $(>100)$ under conventional farming and forest than under organic farming, indicating the limitation of $P$ in the former two land use systems. Indeed, higher acid phosphatase activity under conventional farming and forest is responsible for hydrolyzing organic $P$ to be made 
available for plant growth. Various organic based management practices, i.e., application of farmyard manure and vermicompost, incorporation of crop residues, and cropping system under organic farming, contributed to increases in soil organic matter (SOM) and microbial properties, which play significant roles in maintaining soil fertility status.

The decomposition of native SOM is regulated by availability of nutrients under different land use systems. Microbial-necromass, formed by fast growing r-strategist microorganisms under starvation conditions, contributed to increased decomposition of SOM (i.e. positive priming effect (PE)) following addition of ${ }^{14} \mathrm{C}$ labelled glucose without nutrients to soil under organic farming. Conversely, K (slow growing) and L- (stress tolerant) microbial strategists in soil under conventional farming and forest, respectively, were responsible for the relatively low decomposition process. Addition of either a single nutrient ( $N$ or $P$ ) or multiple nutrients ( $N$ and $P$ ) with $C$ showed opposing effects on decomposition processes in soil under different land use systems. Microorganisms utilized the added $\mathrm{N}$ and $\mathrm{C}$ under conventional farming and forest, which suppressed the decomposition process and caused a negative $\mathrm{PE}$ in these soils. Conversely, the microorganisms activated after $\mathrm{P}$ and $\mathrm{C}$ addition mined SOM to meet their demand for $\mathrm{N}$, resulting in a positive PE in all land use systems. The decomposition of SOM was suppressed in soil under conventional farming and forest, however, microbial biomass was stable after addition of multiple nutrients. This could be due to reduction in active microbial biomass, which contributes to respiration in soil, instead of total microbial biomass. Additionally, bacterial community structure may be modified by protozoan infiltration following $\mathrm{N}$ addition, decelerating the decomposition process in these two land use systems. Microbial biomass increased by $18 \%$ in soil under organic farming after addition of multiple nutrients. Thus, the decomposition process increased to fulfil the metabolic requirements of an increased microbial population, resulting in a strong positive PE. The dominance of fast growing $r$-strategists in organic farming showed that microorganisms will utilize available $C$ and nutrients for their growth, thus, higher incorporation of $C$ into their biomass. Furthermore, microbial immobilization of $\mathrm{N}$ or $\mathrm{P}$ will be higher, which can be released and taken up by plants during turnover of microbial biomass or microbial death. Hence, organic farming has a great potential to promote soil fertility and $\mathrm{C}$ sequestration.

In conclusion, the land-use change to organic farming positively affected soil and microbial properties, resulting in improved soil fertility and enhanced carbon sequestration. Farming, which aims at enhancing soil carbon pools and microbial activity, can address the challenge of sustaining food security while protecting the environment. 


\section{Zusammenfassung}

Landnutzungswandel, insbesondere die Umwandlung von Primärwaldflächen in Ackerland, um die steigende Weltbevölkerung zu ernähren, haben folgenreiche Folgen für die Umwelt, wie beispielsweise die Emission von Treibhausgasen, Biodiversitätsverlust und veränderte Bodenfunktionen. Die Intensivierung der Landwirtschaft mindert weiterhin die Bodenfruchtbarkeit, was sich negativ auf die Nachhaltigkeit der landwirtschaftlichen Produktion auswirkt, und weiter auch den Verlust von Bodenkohlenstoff verantreibt, was wiederum zum Klimawandel beiträgt. Diese Dissertation untersucht den Einfluss von Landnutzungsystemen auf Bodenfruchtbarkeit, dem Priming-Effekt, sowie Kohlenstoffsequestrierung.

Aufgrund der stark agrarisch geprägten Wirtschaft, ist landwirtschaftliche Fläche die wertvollste Ressource in Nepal. Die Untersuchungsfläche im Chitwan-Bezirk liegt in der Region Terai, einer Ebene in Süd-Nepal. Bekannt als die Kornkammer Nepals nimmt die Region Terai 17\% der Landesfläche ein. Die Shorea robusta (Roth)-Wälder besitzen eine hohe Biodiversität, sowie einen hohen wirtschaftlichen Wert. Die Menschen sind extrem auf den Wald als Quelle für Holz und Nichtholzprodukte angewiesen. Nach der Ausrottung der Malaria in den 1950er Jahren führte die Regierung ein (Rück-)siedlungsprogramm für Menschen aus dem Mittelland in die verschiedenen Gebiete der Region Terai ein, was eine massive Entwaldung zwecks Anlage neuer Siedlungen und landwirtschaftlicher Felder bewirkte, die bis heute andauert. Folglich sank die Waldfläche stetig ab. Gleichzeitig wurde die Intensivierung der Landwirtschaft mittels konventioneller Anbaumethoden vorangetrieben, um die wachsende Bevölkerung zu ernähren.

Bodenproben wurden in den drei wichigsten Landnutzungsystemen des Chitwan-Bezirks genommen: Wald, organische Landwirtschaft, sowie konventionelle Landwirtschaft. Die Gehalte an organischen Bodenkohlenstoff (C), Gesamtstickstoff (N), mikrobieller Biomasse-Kohlenstoff, sowie- $N$ und sechs Enzymaktivitäten ( $\beta$-Glukosidase, Cellobiohydrolase, Chitinase, Leucin-Aminopeptidase, Tyrosin-Aminopeptidase, Sulfatase) waren signifikant erhöht in den Flächen, die ökologisch bewirtschaftet wurden, im Vergleich zum Wald oder den Flächen der konventionellen Landwirtschaft, insbesondere ausgeprägt in den Oberböden. Die Aktivität der sauren Phosphatase war signifikant (bis zu sechsfach) erhöht unter konventioneller Bewirtschaftung im Vergleich zur organischen oder zum Wald. Die Beiträge der unterschiedlichen Phosphorfraktionen $(P)$ wurden mittels sequentieller Extraktion nach Hedley (1982) abgeschätzt. Die Konzentrationen des mikrobiellen Biomasse- $\mathrm{P}$, pflanzenverfügbaren $\mathrm{P}$, sowie mittel- oder nicht-verfügbaren $\mathrm{P}$ und Gesamt- $\mathrm{P}$ 
waren viel höher bei organischer Landwirtschaft im Vergleich zu konventioneller bzw. Wald. Allerdings war das Verhältnis von C zu organischem P viel höher (>100) unter konventioneller Bewirtschaftung und im Wald im Vergleich zu organischen Bewirtschaftung, was auf eine P-Limitation in den beiden erst genannten Landnutzungsystemen hindeutet. Auch die Aktivität der sauren Phosphatase, welche rekalzitrante organische $\mathrm{P}$-Verbindungen hydrolysiert und pflanzenverfügbar macht, war im Wald und konventioneller Bewirtschaftung erhöht. Das Aufbringen von Gülle und Vermikompost, das Einarbeiten von Ernterückständen und Fruchtfolgen trugen im organischen Bewirtschaftungsystem dazu bei, dass der Bodenkohlenstoff und die mikrobielle Biomasse erhöht war, welche wichtige Rollen für den Erhalt der Bodenfruchtbarkeit spielen.

Der Abbau der organischen Bodensubstanz (oBS) wird von der Nährstoffverfügbarkeit in den verschiedenen Landnutzungsystemen beeinflusst. Mikrobielle Nekromasse, welche von schnell wachsenden Mikroorganismen (R-Strategen) bei Substratmangel aufgebaut wurde, trug zum erhöhten Abbau der oBS bei. Das heißt, sie bewirkte einen positiven Priming-Effekt (PE) nach Zugabe von C-14-markierter Glukose, aber ohne Zugabe weiterer Nährelemente, zu Bodenproben aus der organischen Bewirtschaftung. Im Gegensatz dazu, waren K- (langsam wachsende) und L-Strategen (stresstolerante Arten) für die relativ niedrigen Abbauraten im Wald bzw. konventionelle Bewirtschaftung verantwortlich. Die Zugabe von entweder einem ( $N$ oder $P$ ) oder mehreren ( $N$ und $P$ ) Nährstoffen bewirkte gegensätzliche Effekte bezüglich der Abbauprozesse in unterschiedlichen Landnutzungsystemen. Mikroorganismen nutzen präferentiell den zugegebenen $\mathrm{N}$ und $\mathrm{C}$ im konventionellen System bzw. im Wald, was den Abbau der oBS hemmte und damit einen negativen PE bedeutete. Hingegen aktivierte die C- und P-Gabe den Abbau der oBS, um den mikrobiellen N-Bedarf zu decken, das heißt ein positiver PE in allen Landnutzungsystemen. Der Abbau der oBS war in Wald und konventioneller Bewirtschaftungsweise gehemmt, allerdings veränderte sich die Menge der mikrobiellen Biomasse nicht bei Gabe mehrerer Nährstoffe. Dies könnte mit einer Reduktion der aktiven mikrobiellen Biomasse zusammenhängen, die die Umsatzprozesse im Boden durchführt, im Gegensatz zur gesamten mikrobiellen Biomasse. Weiterhin könnte sich die Zusammensetzung der bakteriellen Gemeinschaft nach der N-Zugabe aufgrund von Protozoen geändert haben, was die mikrobiellen Umsätze in diesen beiden Landnutzungsystemen abgebremst haben könnte. Bei mehrfacher Zugabe im organischen System wuchs die mikrobielle Biomasse um 18\%. Damit erhöhte sich auch der Abbau der oBS zur Deckung des Nährstoffbedarfs der wachsenden mikrobiellen Population, was 
insgesamt einen stark positiven PE bewirkte. Die Dominanz schnellwachsender $r$ Strategen in der organischen Bewirtschaftungsweise zeigte, dass Mikroorganismen verfügbaren $C$ und Nährstoffe für ihr Wachstum nutzen und vermehrt $C$ in ihre Biomasse einbauen. Weiterhin immobilisieren sie $N$ und $P$. Diese gespeicherten Nährstoffe können nach mikrobieller Umsetzung von Pflanzen aufgenommen werden. Eine organische Bewirtschaftungsweise hat also ein großes Potenzial für die Steigerung der Bodenfruchtbarkeit und C-Sequestrierung.

Zusammenfassend kann sich ein Landnutzungswandel hin zu einer ökologischen Landwirtschaft positiv auf Boden- und mikrobielle Parameter auswirken, was widerrum verbesserte Bodenfruchtbarkeit und erhöhte C-Sequestrierung bedeutet. Eine Bewirtschaftungsweise, die auf Verbesserung der Bodenkohlenstoffmengen und mikrobielle Aktivität abzielt, könnte die Herausforderung der Ernährungssicherung lösen und dabei zum Umweltschutz beitragen. 


\section{Acknowledgements}

Firstly, I would like to express my sincere gratitude to my advisers, Prof. Dr. Yakov Kuzyakov and Prof. Dr. Michaela Dippold, Dr. Evgenia Blagodatskaya, and Prof Helena Kahiluoto for their continuous support of my Ph.D. studies and related research and for motivation during my studies. Their guidance helped me during research and the writing of this thesis.

I would also like to acknowledge Expert4Asia scholarship\Erasmus Mundus for awarding me a scholarship. Special thanks also goes to Prof. Dr. Michaela Dippold for providing financial support after finishing the Expert4Asia scholarship. I am very grateful to the Institute of Forestry, Hetauda Campus, Tribhuwan University for providing me with study leave.

I am very thankful to all technical staff for their assistance and guidance in the laboratory. Special thanks to Karin, Anita, Ingrid, Susan - Vielen Dank!

I would like to thank my colleagues of the Department of Agricultural Soil Science, Soil Science of Temperate Ecosystems, and the Division of Soil Hydrology for all their professional and personal support during this study. I would also like to thank my lunch group (Duyen, Bahar, Kazem, Kyle, Amit, Shibin, and Katayoun), Chinese group (Xiaomin, Suri, Huadong, Ling Ling, and Zwei), African group (Ezekiel, Nelly, Kevin, and Emmanuel), and GG group (Nina, Lika, Dipti, Alex, Mia and Valentina). Special thanks to friends cum family: Deejay, Emma, Josh, and Kamini for their love and kind support during thick and thin periods of my life in Goettingen. I am thankful to my Nepali friends and family for providing homely environment in Goettingen.

I am grateful to Josh and Kyle for English editing of the manuscripts and Callum for German translation of the summary included in this thesis.

Finally, I am always indebted to my parents (Ishwori and Sanu), my sisters (Laxmi and Sangita), and my brother in law (Badri) for their unconditional love, support, guidance and encouragement throughout the writing of this thesis and my life in general. I want to dedicate this dissertation to my family and dear niece Kashvi. They are my strength and motivation to finish and succeed in this beautiful journey. 


\section{Extended Summary}

\subsection{General Introduction}

\subsubsection{Land-use change}

Land-use change is one of the main drivers of global environmental disturbance, greatly contributing to climate change, loss of ecosystem services and species extinctions (Turner et al., 2007; Tilman et al., 2001). 800 years ago, 50\% of the Earth's surface area was covered by forests, compared with $30 \%$ today (Lambin et al., 2003). Over the last three centuries, total forests and woodlands has diminished by an estimated 1.2 billion ha globally, while area under pasture and grassland vegetation has decreased by 560 million ha. However, agricultural land has increased by 1.2 billion ha (Ramankutty and Foley, 1998). During the period from $1980-2000$, more than $50 \%$ of the new agricultural land across the tropics came mainly at the expense of intact forests and another $28 \%$ from disturbed forests (Lambin and Meyfroidt, 2011).

\subsubsection{Agricultural intensification and its consequences}

Land-use change, especially from forest to intensive agriculture, is driven by the increasing food demands of the growing world population (Tilman et al., 2001; Geisssen et al., 2009; Guillaume et al., 2015). During the "Green Revolution" beginning in the 1960s, food production was doubled by improving crop varieties; chemical fertilizers, pesticide, irrigation, and mechanization (Naylor, 1996; Maston et al., 1997), leading to intensive land use and the conversion of natural ecosystems into agroecosystems (Stevenson et al., 2013). However, the multiple environmental impacts contingent upon this increased yield through intensive agriculture cannot be ignored (Tilman, 1999). Agricultural intensification has negative local consequences (i.e. erosion, lower soil fertility, and reduced biodiversity) (Dorzo and Raven, 2003), regional consequences (i.e. pollution of ground water and eutrophication of rivers and lakes) (Vistousek et al., 1997) and global consequences (i.e. impacts on atmospheric constituents, greenhouse gas emission and climate change) (Maston et al., 1997; Burnery et al., 2010).

Intensive agriculture alters the physical, chemical, and biological properties of soil, affecting soil fertility and ultimately reducing the future capacity of the land for sustainable crop production (Geissen et al 2009; Maston et al., 1997; Mganga et al., 2015). Moreover, loss of soil organic carbon (SOC) is a well-known consequence of land-use change, especially from natural ecosystems to agricultural land (van Noordwijk et al., 1997; Houghton, 2012). Therefore, there is a growing global interest in the assessment of land use and 
management effects on soil fertility, carbon dynamics, and sequestration, especially in tropical ecosystems.

\subsubsection{Soil fertility}

Soil organic matter is the main source of nutrients for plant growth. It represents the major C reservoir in biosphere-atmosphere system (Mganga, 2015) and forms the molecular frameworks on which SOM nutrients are bound (Guillaume, 2015). Consequently, SOC is regarded as an "umbrella" property of soil fertility because decreases in SOC result in reductions in other soil fertility properties (Guillaume, 2015).

In terrestrial ecosystems, $\mathrm{N}$ and $\mathrm{P}$ are considered as the major limiting nutrients for plant growth, and are thus regarded as the main constraining factors in agricultural production. However, plants and microorganisms have developed strategies that allow them to persist under nutrient limitations (Maston et al., 1997). Extracellular enzymes, which are mainly secreted by microorganisms, play vital roles in nutrient cycling and SOM decomposition (Klose and Tabatabai, 2002). For example, $\beta$-glucosidase and cellobiohydrolase activity are enzymes responsible for cellulose degradation (German et al. 2011), xylanase is responsible for breaking down hemicelluloses (German et al. 2011), acid phosphomonoesterase hydrolyzes (mono) ester bonds of organic $\mathrm{P}$ to phosphate under acidic conditions (Eivazi and Tabatabai 1977; Malcolm, 1983), and sulfatase hydrolyzes sulfate esters. Activities of leucine and tyrosine aminopeptidase are involved in the hydrolysis of leucine and tyrosine residues from the amino-termini of protein or peptide substrates (Rawlings et al. 2006). Chitinase activity accomplishes the decomposition of chitin to lower molecular weight chitooligomers (Hamid et al. 2013). Extracellular enzymes involved in the C-cycle (xylanase, cellobiohydrolase, B-glucosidase), $\mathrm{N}$-cycle (chitinase, leucine and tyrosine aminopeptidase), P-cycle (acid phosphatase), and S-cycle (sulfatase) are important because they catalyze the rate-limited steps of decomposition and nutrient cycling (Koch et al., 2007; Blagodatskaya and Kuzyakov, 2008). Hence, enzyme activity has been suggested as indicator of soil productivity or microbial activity (Weaver et al., 1994; Dick et al., 1996) and can be used as an accurate 'soil fertility index' (Skujins, 1976; Mganga et al., 2015).

Land use and management practices i.e. fertilizer application, cropping system, tillage, and incorporation of crop residues have significant effects on soil and microbial properties, i.e., microbial biomass and enzyme activities (Maharjan et al., 2017). Hence, microbial and biochemical characteristics of soil have been proposed as indicators of soil quality in both natural and agricultural systems (Karlen et al., 1997; Mganga et al., 2015). Thus, this study 
will try to develop a better understating how management practices under different land use systems affects soil microbial properties.

\subsubsection{Soil organic carbon, priming effect and global carbon cycle}

Land-use change is one of the most important factors affecting soil organic carbon (SOC) stock and dynamics (Van Noordwijk et al., 1997; Guillaume et al., 2015). Among the various soil properties affected by land-use change, the reduction of SOC draws the greatest attention, as it regulates the global terrestrial carbon cycle (Guillaume, 2015). With 2300 Gt C (carbon) in the uppermost $3 \mathrm{~m}$, SOC is considered as the largest terrestrial C pool that exchanges with the biological (560 Gt) and atmospheric (760 Gt) C pools (Jobbágy \& Jackson, 2000; Lal, 2004). About 30 \% of world's SOC is stored in tropical soils (Jobbágy \& Jackson, 2000). Hence, small changes to the tropical SOC pools can considerably alter the concentration of atmospheric $\mathrm{CO}_{2}$ (Guillaume, 2015).

Priming effect (PE) is the phenomenon that describes changes in the decomposition rate of SOM due to changes in microbial activity as a response to altered availability of organic $\mathrm{C}$ and nutrients (Kuzyakov, 2010). In terrestrial ecosystems, labile C and nutrients are present in different amounts and ratios. Thus, it is essential to understand how PE responds to variations in the proportions of labile substrate additions to better understand the decomposition process (Qiao et al., 2016). Additionally, it is critical to understand the factors and mechanisms controlling PE, which has a significant effect on soil $C$ storage and turnover. Abiotic factors, i.e., temperature and soil moisture, are the major indirect drivers of $\mathrm{C}$ turnover in soil. Additionally, biotic factors, i.e., soil fauna, enzymes, microbial community, microbial growth strategists, and rhizospheres, directly affect the decomposition of native SOM (Blagodatskaya and Kuzyakov, 2008; Blagodatskaya et al., 2007). Prior studies showed that specific groups of microorganisms (e.g. fungi) produce enzymes using labile $C$ to decompose SOM (De Deyn et al., 2008). Furthermore, Kstrategists (slow growing) are believed to be responsible for PE in nutrient-poor soils (Fontaine et al. 2003). However, both K-and r-strategists (fast growing) can induce PE by contrasting mechanisms depending on the availability of nutrients (Chen et al., 2014). Thus, PE is regulated by microbial growth strategies, which are influenced by the nutrient status of soils under different land use systems.

Land use change from forest to intensive agriculture accelerates the depletion of SOM. Additionally, crop residues are removed via burning and/or livestock feeding (Mganga, 2016). Consequently, soil becomes nutrient deficient, producing a major constraint for agriculture production. Hence, farmers apply organic and inorganic fertilizers to overcome soil nutrient losses and to increase plant productivity (MA, 2005). Soil biochemical and 
biological properties are significantly affected by fertilization (Liang et al., 2014). Recent studies showed divergent results i.e. positive or negative or no PE after $\mathrm{N}$ fertilization (Cleveland and Townsend, 2006; Waldrop and Zak, 2006; Liu and Greaver, 2010). Thus, it is a challenging task to predict the ecosystem response to $\mathrm{N}$ fertilization in contrasting land use systems (Poeplau et al., 2016). However, evidence from previous studies demonstrates that $\mathrm{P}$ addition significantly increased soil $\mathrm{CO}_{2}$ respiration leading to $\mathrm{C}$ losses, mostly in forest soils (Cleveland et al., 2002; Cleveland and Townsend, 2006; Fisk et al., 2015). Not surprisingly, the potential effects of multiple nutrients addition on SOM decomposition have rarely been addressed under different land use systems (Fornara et al., 2013). Thus, the analysis of $C$ sequestration remains incomplete without elucidating the effect of multiple nutrients addition on SOM decomposition.

Thus, this study will try to develop a better understating of how SOM decomposition responds to the inputs of labile $\mathrm{C}$ and different nutrients and how it affects soil fertility and carbon sequestration.

\subsection{Objectives}

The main objectives of the present work were as follows:

1. Impact assessment of land-use change on $\mathrm{C}$ and nutrient cycling (study 1 )

- quantify soil properties (organic $\mathrm{C}$ and Total $\mathrm{N}$ ), and microbial properties i.e. (microbial biomass $\mathrm{C}$ and $\mathrm{N}$ and enzyme activities involved in $\mathrm{C}, \mathrm{N}, \mathrm{P}$ and $\mathrm{S}$ cycle) following forest conversion to organic and conventional farming.

- identify the mechanisms controlling soil and microbial properties as indicators of soil fertility

2. Assessment of the impact of land-use change on P availability (study 2)

- quantify different fractions of $P$ in forest, organic and conventional farming.

- identify the factors/mechanisms controlling $P$ availability

3. Analyze the effect of fertilization on soil organic matter decomposition in forest, organic and conventional farming (study 3 and study 4)

- assess the effects of addition of low molecular weight $C$ input, i.e. 14C labeled glucose with single nutrient ( $N$ or $\mathrm{P}$ ) vs multiple nutrients $(\mathrm{N}+\mathrm{P})$ on decomposition of SOM in forest, organic and conventional farming (study 3 )

- identify mechanisms controlling decomposition process with addition of single vs multiple nutrients in forest, organic and conventional farming (study 3 )

- estimate the kinetics of microbial growth parameters in forest, organic and conventional farming (study 3 and 4) 


\subsection{Materials and Methods}

\subsubsection{Description of the study site and soil sampling}

The study site in "Chitwan district" lies in the Terai region, a plain in southern Nepal. The Terai region covers $17 \%$ of the country's total land area. It is also known as the grain house of Nepal. Forest covers 411,580 ha $(20.41 \%)$ of the region's total land area $(2,016,998 \mathrm{ha})$ (FRA/DFRS, 2014), dominated by Shorea robusta and possessing high economic value and biological diversity. After eradication of malaria in the 1950s, a resettlement and migration scheme from the Middle Mountain region to different parts of the Terai region was induced. As the population increased, massive deforestation occurred to make way for cultivation and new settlements. Today, the population growth rate of the region is $1.75 \%$, the highest in Nepal, and is consequently increasing the pressure on forest areas (FRA/DFRS, 2014). Agricultural intensification through conventional farming practices is also being implemented to feed the growing population.

Soil samples were collected from three selected land-use systems: forest, organic farming and conventional farming. Both farming sites were located in Fulbari Village Development Committee (VDC) and the forest site was located in Patihani VDC. The climate is subtropical with annual rainfall of $1763 \mathrm{~mm}$. The mean temperature is $220 \mathrm{C}$ and annual average temperature is $30 \mathrm{oC}$. The soils at the study sites are Gleyic Cambisols (organic farming and forest) and Eutric Cambisol for the conventional farming site (IUSS Working Group WRB, 2015). The texture of the soil at all sites is sandy loam.

The organic farm site has been under organic farming practices for 15 years. The crop rotations are maize + rice + vegetables/ mustard and maize + rice + wheat/lentils for the organic and conventional farms, respectively. The organic farm was under vegetable farming during soil sampling while the conventional farm was fallow with remaining rice stubbles. The broad leaf forest is dominated by Shorea robusta, commonly known as Sal. The leaves of Sal are collected by local people for performing social and religious activities. Additionally, the canopy cover and regeneration is very low in forest. The application of pesticide was found only in conventional farming. Detailed descriptions of land uses are provided in Table S1 (Maharjan et al., 2017, modified). 
Table S1 Description of land use and soil properties (Ap/Ah horizon)

\begin{tabular}{|c|c|c|c|c|c|}
\hline Land use & $\begin{array}{l}\text { Management } \\
\text { Practices }\end{array}$ & $\underset{\left(\mathrm{H}_{2} \mathrm{O}\right)}{\mathrm{pH}}$ & $\begin{array}{l}\text { Organic } \\
\text { Carbon } \\
\left(\mathrm{mg} \mathrm{C} \mathrm{g} \mathrm{g}^{-1)}\right.\end{array}$ & $\begin{array}{c}\text { Total } \\
\text { Nitrogen } \\
\left(\mathrm{mg} \mathrm{N} \mathrm{g}^{-1}\right)\end{array}$ & $\begin{array}{c}\text { Total } \\
\text { Phosphorus } \\
\left(\mathrm{mg} \mathrm{P}^{-1} \text { ) }\right.\end{array}$ \\
\hline $\begin{array}{l}\text { Organic } \\
\text { farming = } 15 \\
\text { years }\end{array}$ & $\begin{array}{ll}\text { Farmyard } & \\
\text { manure:10 } & \text { ton } \\
\text { ha }^{-1} & \mathrm{yr}^{-1}\end{array}$ & 7.5 & 21 & 1.9 & 332 \\
\hline & Vermicomposting & & & & \\
\hline $\begin{array}{l}\text { Conventional } \\
\text { farming }\end{array}$ & $\begin{array}{l}\text { Urea: } 60 \mathrm{~kg} \mathrm{ha}{ }^{-1} \\
\mathrm{yr}^{-1} \\
\text { Potassium: } 15 \mathrm{~kg} \\
\mathrm{ha}^{-1} \mathrm{yr}^{-1}\end{array}$ & 5.0 & 15 & 1.2 & 130 \\
\hline Forest & $\begin{array}{l}\text { Collection of leaf } \\
\text { litter for social } \\
\text { and religious } \\
\text { activities }\end{array}$ & 5.5 & 9 & 0.7 & 89 \\
\hline
\end{tabular}
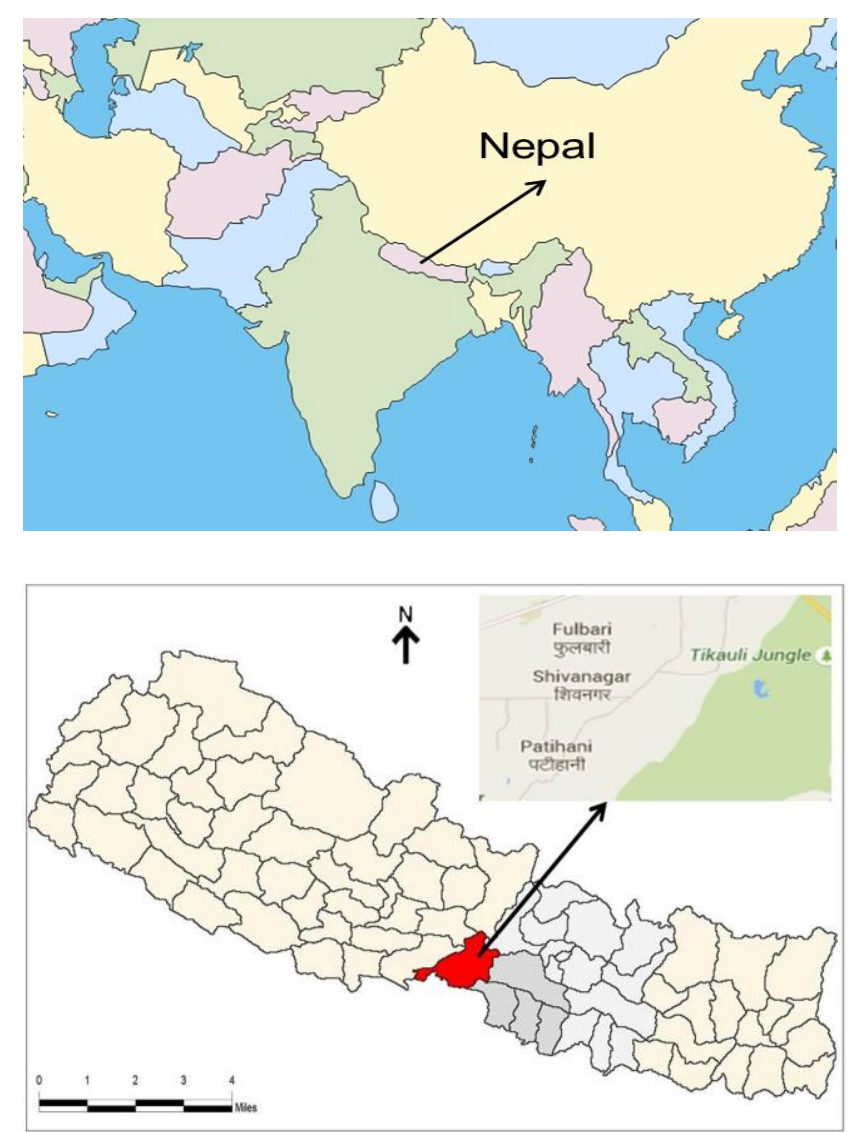

Figure S1 Location of the Nepal in Asia (top) and map of Chitwan district, Nepal (bottom).Source: https://www.thinglink.com/scene/693071828536524800,http://manakamanagroup.com/chitwanheritage/ 

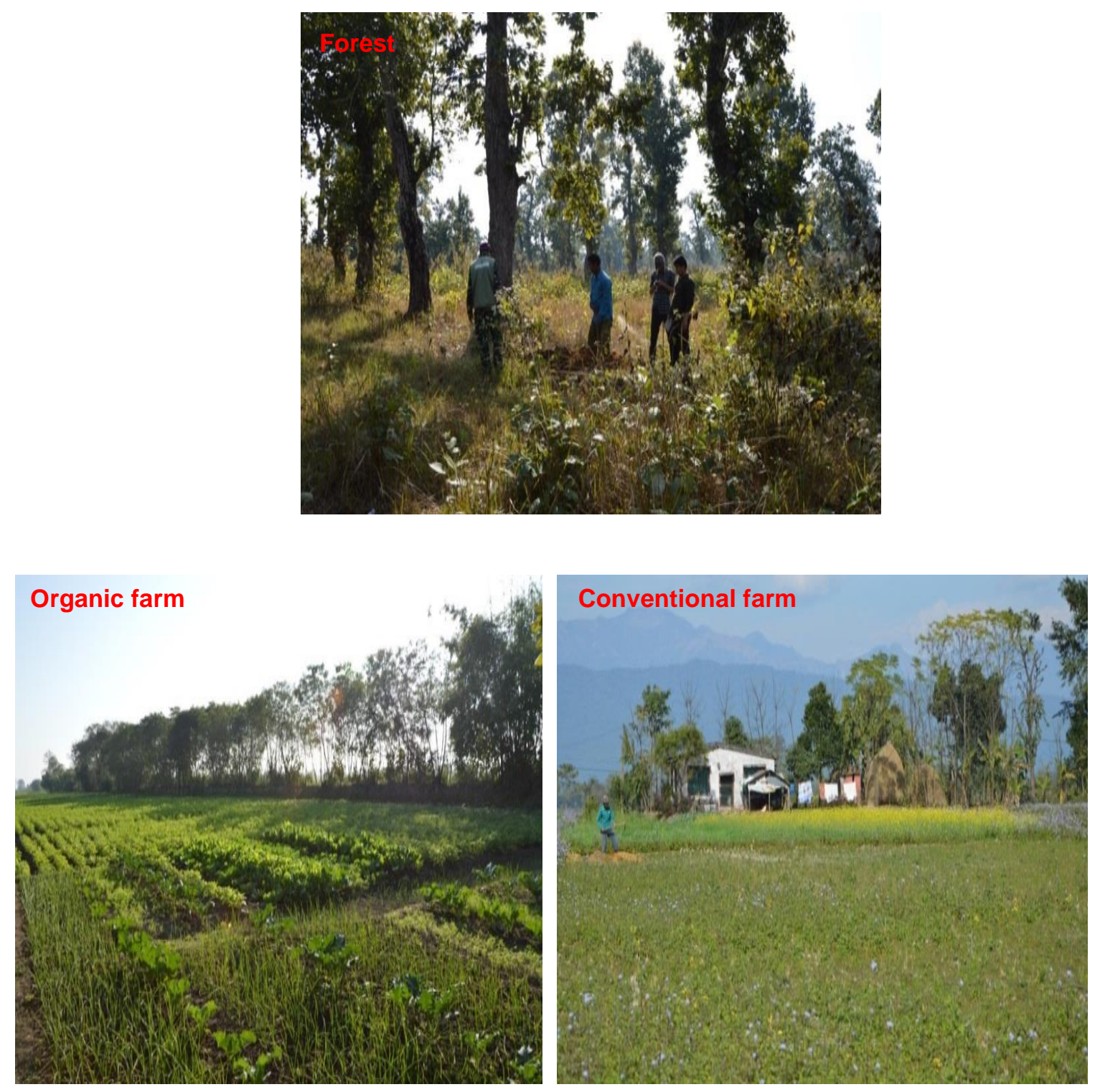

Figure S2 Three land-use systems i.e. forest, organic and conventional farming in Chitwan district , Nepal (Source: Field work, January 2015)

\subsubsection{Experimental design, method and analysis-study 1}

Soils from the three land use systems were sampled from 0 to $100 \mathrm{~cm}$ depth at intervals of $10 \mathrm{~cm}$. Samples were kept cold $\left(4^{\circ} \mathrm{C}\right)$ during transportation to the laboratory. Plant remains, debris, and roots were removed using tweezers. The field-moist soil (70\% of WHC) was allowed to equilibrate at room temperature for $24 \mathrm{~h}$ prior to analysis. Soil and microbial properties were measured under different land use systems. A summary of the materials and methods used in this study is given in Table S2 below. 
Table S2 Summary of the materials and methods used in study 1

\begin{tabular}{|c|c|}
\hline Objective & Method and Analysis \\
\hline $\begin{array}{l}\text { Determination of organic } \\
\mathrm{C} \text { and Total } \mathrm{N} \text { content in } \\
\text { the soil }\end{array}$ & $\begin{array}{l}\text { Elementar Vario EL analyzer (Elementar Analysensysteme } \\
\text { GmbH, Germany). }\end{array}$ \\
\hline $\begin{array}{l}\text { Estimation microbial } \\
\text { biomass }(\mathrm{C} \text { and } \mathrm{N})\end{array}$ & $\begin{array}{l}\text { Chloroform fumigation-extraction method (Vance et al. 1987) } \\
\text { with slight modification. }\end{array}$ \\
\hline \multirow{3}{*}{$\begin{array}{l}\text { Measurement of enzyme } \\
\text { activities }\end{array}$} & $\begin{array}{l}\text { Extracts (fumigated and unfumigated) were measured by } \\
\text { catalytic oxidation (Multi N/C 2100) Analytik Jena, Jena. }\end{array}$ \\
\hline & $\begin{array}{l}\text { Eight enzymes i.e. C-cycle enzymes ( } \beta \text {-glucosidase activity, } \\
\text { cellobiohydrolase activity, and xylanase activity), N-cycle } \\
\text { enzymes (chitinase activity, leucine aminopeptidase activity, } \\
\text { and tyrosine aminopeptidase activity), P-cycle enzyme (acid } \\
\text { phosphatase activity), and S-cycle (sulfatase activity) were } \\
\text { measured (SIGMA, Germany). }\end{array}$ \\
\hline & $\begin{array}{l}\text { Fluorescence was measured in microplates at an excitation } \\
\text { wavelength of } 355 \mathrm{~nm} \text { and an emission wavelength of } 460 \\
\mathrm{~nm} \text {, slit width of } 25 \mathrm{~nm} \text {, with a Victor3 1420-050 Multi label } \\
\text { Counter (PerkinElmer, USA). }\end{array}$ \\
\hline
\end{tabular}

\subsubsection{Experimental design, method and analysis-study 2}

To assess the effect of land use on $P$ fractions, soils from the three land use systems were sampled from 0 to $20 \mathrm{~cm}$ depth at intervals of $10 \mathrm{~cm}$. Twenty two grams of air-dried soil from three different land use systems were placed into a 100-ml jar. The soil was adjusted to $70 \%$ of the $\mathrm{WHC}$ and incubated for 14 days at $22^{\circ} \mathrm{C}$ prior to sequential extraction to restore the equilibrium due to disturbances from drying and sieving (Hedley et al., 1982). $P$ stocks presented in $\mathrm{kg} \mathrm{P} \mathrm{ha}^{-1}$ were calculated for the soil depth intervals $0-10$ and $10-20$ cm using the following equation (Maranguit et al., 2017):

$S=x^{*} \rho^{*} Z$

where "S" is the P stock for fixed depths and " $x$ " is the soil $P$ content at the selected depth " $z$ ", and " $\rho$ " is the soil bulk density. A summary of the materials and methods used in this study are provided in Table S3 below. 
Table S3 Summary of the materials and methods used in study 2

\begin{tabular}{|c|c|}
\hline Objectives & Method and Analysis \\
\hline \multirow[t]{2}{*}{$\begin{array}{l}\text { Determination of different } \\
\text { fractions of } P\end{array}$} & $\begin{array}{l}\text { Sequential fractionation of } P \text { in soil (Hedley et al. } 1982 \\
\text { modified by Tiessen and Moir (1993). }\end{array}$ \\
\hline & $\begin{array}{l}\text { The following fractions are extracted (i) readily available P } \\
\text { i.e. } \mathrm{NaHCO}_{3} \text {-inorganic }(\mathrm{Pi}) \text { and organic (Po) ii) moderately } \\
\text { available } \mathrm{P} \text { i.e. } \mathrm{NaHCO}_{3}-\mathrm{Pi} \text { and } \mathrm{Po} \text { (iii) non-available P i.e. } \\
\mathrm{HCl}-\mathrm{Pi} \text { and } \mathrm{Po} \text {. }\end{array}$ \\
\hline \multirow[t]{2}{*}{$\begin{array}{l}\text { Determination } \\
\text { microbial biomass } P\end{array}$} & $\begin{array}{l}\text { Chloroform fumigation-extraction method (Kouno et al., 1995; } \\
\text { Cheesman et al., } 2010 \text { modified by Yevdokimov and } \\
\text { Blagodatskaya, 2014) }\end{array}$ \\
\hline & $\begin{array}{l}\text { Measurement of easily available microbial } P \text { i.e. microbial } \\
\text { biomass } P \text {. }\end{array}$ \\
\hline $\begin{array}{l}\text { Measurement of enzyme } \\
\text { activity }\end{array}$ & $\begin{array}{l}\text { Artificial fluorogenic substrate i.e. 4-methylumbiliferyl } \\
\text { phosphate for acid phosphatase activity }\end{array}$ \\
\hline
\end{tabular}

\subsubsection{Experimental design, method and analysis-study 3}

Soil samples were collected from the upper $0-20 \mathrm{~cm}$ depth from four random sampling locations for each of the three land use systems. Twenty-two grams (oven-dried weight) of soil from each land use system was weighed into $100-\mathrm{ml}$ jars. The soil was adjusted to $50 \%$ of the $\mathrm{WHC}$ and pre-incubated for 15 days at $22^{\circ} \mathrm{C}$. After pre-incubation, $\mathrm{N}$ as $\mathrm{KNO}_{3}$ (200 kg ha-1) and $\mathrm{P}$ as $\mathrm{KH}_{2} \mathrm{PO}_{4}\left(120 \mathrm{~kg} \mathrm{ha}^{-1}\right)$ was added to all samples except for control and glucose only treatments. After 15 days of nutrient addition, soil was amended either with distilled water (control treatment) or with glucose (other treatments). Uniformly-labeled ${ }^{14} \mathrm{C}$ glucose was added at a rate of $239 \mathrm{\mu g} \mathrm{C} \mathrm{g}^{-1}$ soil (final activity of $7514 \mathrm{DPM} \mathrm{g}^{-1}$ soil), 184 $\mu \mathrm{g} \mathrm{C} \mathrm{g}{ }^{-1}$ soil (final activity of $7401 \mathrm{DPM} \mathrm{g}^{-1}$ soil) and $132 \mu \mathrm{g} \mathrm{C} \mathrm{g}^{-1}$ soil (final activity of 7485 $\mathrm{DPM} \mathrm{g}^{-1}$ soil ) in organic farming, conventional farming and forest, respectively. The amount of glucose addition was equivalent to $30 \%$ of initial MBC in each land use system. All in all, there were five treatments for each land use system: 1) Control (water only, Ctl), 2) Glucose only (C) 3) Glucose+Nitrogen $(C+N)$, 4) Glucose+Phosphorus $(C+P)$, and 5) Glucose+Nitrogen+Phosphorus $(\mathrm{C}+\mathrm{N}+\mathrm{P})$. Each treatment had four replicates for each respective land use system at each sampling date.

Priming effects (PE) was calculated via the following equation: 
$\mathrm{PE}=\left[\mathrm{CO}_{2}\right]_{\text {total- }}\left[\mathrm{CO}_{2}\right]_{\mathrm{G}}-\left[\mathrm{CO}_{2}\right]_{\text {control }}$

where $\left[\mathrm{CO}_{2}\right]_{\text {total }},\left[\mathrm{CO}_{2}\right]_{\mathrm{G}}$ and $\left[\mathrm{CO}_{2}\right]_{\text {control }}$ represent $\mathrm{CO}_{2}$ emissions from soil after nutrients treatment, only glucose treatment and without any amendment, respectively. Priming effects are presented as $\mu \mathrm{g} \mathrm{C}$ of extra $\mathrm{CO}_{2}$ per gram of soil. A summary of the materials and methods used in this study are provided in Table S4 below.

Table S4 Summary of the materials and methods used in study 3

\begin{tabular}{|c|c|}
\hline Objectives & Method and Analysis \\
\hline $\begin{array}{l}\text { Partitioning sources of } \\
\mathrm{CO}_{2} \text { produced from soil }\end{array}$ & $\begin{array}{l}{ }^{14} \mathrm{C} \text { labeled glucose was uniformly added to soil as aqueous } \\
\text { solution. }\end{array}$ \\
\hline $\begin{array}{l}\text { Estimating soil respiration } \\
\left(\text { Total } \mathrm{CO}_{2}\right)\end{array}$ & $\begin{array}{l}\text { Static alkali absorption method was used to determine soil } \\
\text { respiration. Total } \mathrm{CO}_{2} \text { trapped in the alkali solution }(1.0 \mathrm{M} \\
\mathrm{NaOH} \text { ) was precipitated with } 0.5 \mathrm{M} \text { barium chloride }\left(\mathrm{BaCl}_{2}\right) \text {. } \\
\mathrm{NaOH} \text { was titrated with } 0.025 \mathrm{M} \mathrm{HCl} \text { (Hydrochloric acid) } \\
\text { against phenolphthalein indicator using the Titronic }{ }^{\circledR} \text { Basic } \\
\text { Burette (Camlab Ltd, Cambridge, UK). }\end{array}$ \\
\hline $\begin{array}{l}\text { Determining the amount } \\
\text { of added glucose } \\
\text { mineralized to }{ }^{14} \mathrm{CO}_{2}\end{array}$ & $\begin{array}{l}{ }^{14} \mathrm{C} \text { activity trapped in alkali solution was mixed with } \\
\text { scintillation cocktail Rotiszint Eco Plus (Carl Roth Company, } \\
\text { Germany) and measured using Hidex } 300 \mathrm{SL} \text { Automatic } \\
\text { TDCR Liquid Scintillation Counter (Beckman Coulter Inc., } \\
\text { USA) }\end{array}$ \\
\hline $\begin{array}{l}\text { Determining }{ }^{14} \mathrm{C} \\
\text { microbial biomass }\end{array}$ & $\begin{array}{l}\text { Extracts (fumigated and unfumigated) were mixed with } \\
\text { scintillation cocktail Rotiszint Eco Plus (Carl Roth Company, } \\
\text { Germany) and measured using Hidex } 300 \text { SL Automatic } \\
\text { TDCR Liquid Scintillation Counter (Beckman Coulter Inc., } \\
\text { USA) }\end{array}$ \\
\hline
\end{tabular}

\subsubsection{Experimental design, method and analysis-study 4}

The kinetic parameters of microbial growth responses were estimated (Blagodatskaya et al., 2000 with modification). Soil samples (equivalent to $0.5 \mathrm{~g}$ dry soil) were amended with a solution $(50 \mu \mathrm{l})$ containing glucose $\left(10 \mathrm{mg} \mathrm{g}^{-1}\right.$ of soil) and a salts solution: $\left(\mathrm{NH}_{4}\right)_{2} \mathrm{SO}_{4} 1.9 \mathrm{mg}$ $\mathrm{g}^{-1}$ and $\mathrm{MgSO}_{4}$ * $7 \mathrm{H}_{2} \mathrm{O} 3.8 \mathrm{mg} \mathrm{g}^{-1}$ of soil. The salt solution contained different concentrations of $\mathrm{K}_{2} \mathrm{HPO}_{4}$ for organic farming (2.03 $\mathrm{mg} \mathrm{g}^{-1}$ soil), conventional farming $(0.16$ $\mathrm{mg} \mathrm{g}^{-1}$ soil), and forest soil $\left(0.50 \mathrm{mg} \mathrm{g}^{-1}\right.$ soil). Similarly, the concentration of $\mathrm{KH}_{2} \mathrm{PO}_{4}$ was $0.18,1.63$, and $1.9 \mathrm{mg} \mathrm{g}^{-1}$ for soil under organic farming, conventional farming, and forest, respectively. The amount of mineral salts was selected based on the soil $\mathrm{pH}$ and buffering 
capacity to change soil pH less than 0.1 after substrate addition (Blagodatskaya et al., 2007). The following equation was used to calculate $\mathrm{CO}_{2}$ emissions (Gilmullina et al., 2017).

$\mathrm{C}\left(\mathrm{C}-\mathrm{CO}_{2}\right)=\left(0.383^{*} \Delta \mathrm{EC}\right) * \mathrm{~V} / \mathrm{m}$

Where $\mathrm{C}\left(\mathrm{C}-\mathrm{CO}_{2}\right)$ is $\mathrm{C}-\mathrm{CO}_{2}$ concentration ( $\mu \mathrm{g} \mathrm{\textrm {g } ^ { - 1 }}$ soil), $\Delta \mathrm{EC}$ is electrical conductivity change $(\mu \mathrm{s}), V$ is volume of alkali $(\mathrm{ml})$ and $\mathrm{m}$ is weight of dry soil $(\mathrm{g})$. A summary of the materials and methods used in this study are provided in Table S5 below. Model Maker-3 software (SB Technology Ltd.) used to measure the growth parameters. Maximum specific growth rate of soil microorganisms was estimated by fitting the parameters of the equation. Lag period and \% of active microbial biomass calculated by using equations (Blagodatsky et al., 2000). Total microbial biomass calculated by substrate induced respiration (Anderson and Domsch, 1978; Hoang et al., 2016).

Table S5 Summary of the materials and methods used in study 4

\begin{tabular}{ll}
\hline \multicolumn{1}{c}{ Objectives } & \multicolumn{1}{c}{ Method and Analysis } \\
\hline Estimating soil respiration & Eppendrop containing soil sample was placed in plastic tubes \\
$\left(\right.$ Total $\left.\mathrm{CO}_{2}\right)$ & containing $3 \mathrm{ml}$ of $\mathrm{NaOH}$. Then each cell was inserted to \\
& RABBIT (The Rapid Automated Bacterial Impedance \\
& Technique) system for measuring the $\mathrm{CO}_{2}$ emission at $25^{\circ} \mathrm{C}$ \\
& for $59 \mathrm{~h}$ (Gilmullina et al., 2017). \\
\hline
\end{tabular}

\subsection{Main results and discussion}

\subsubsection{Soil and microbial properties}

Total organic $\mathrm{C}$ and $\mathrm{N}$ and soil microbial biomass were higher in organic farming than in conventional farming and forest topsoil (Fig S3). Enzyme activities other than xylanase and acid phosphatase were higher in organic farming than in conventional farming and forest topsoil. In the subsoil, microbial biomass was similar among land-use systems, although enzyme activities were slightly higher under organic farming.

Various management practices under organic farming, i.e., application of farmyard manure and vermicompost, incorporation of crop residue, rhizodeposits through different cropping systems, support higher microbial biomass, leading to enhanced enzyme activities in organic farming soil compared to other land use systems. Incorporation of rice stubble and limitation of available phosphorus leads to higher xylanase and acid phosphatase activities, respectively, in conventional farming soil than other land use systems. Collection of leaf 
litter for social and religious activities by villagers results in deficiencies of labile $\mathrm{C}$ and $\mathrm{N}$, resulting in lower enzyme activities in forest soil (Fig. S4).
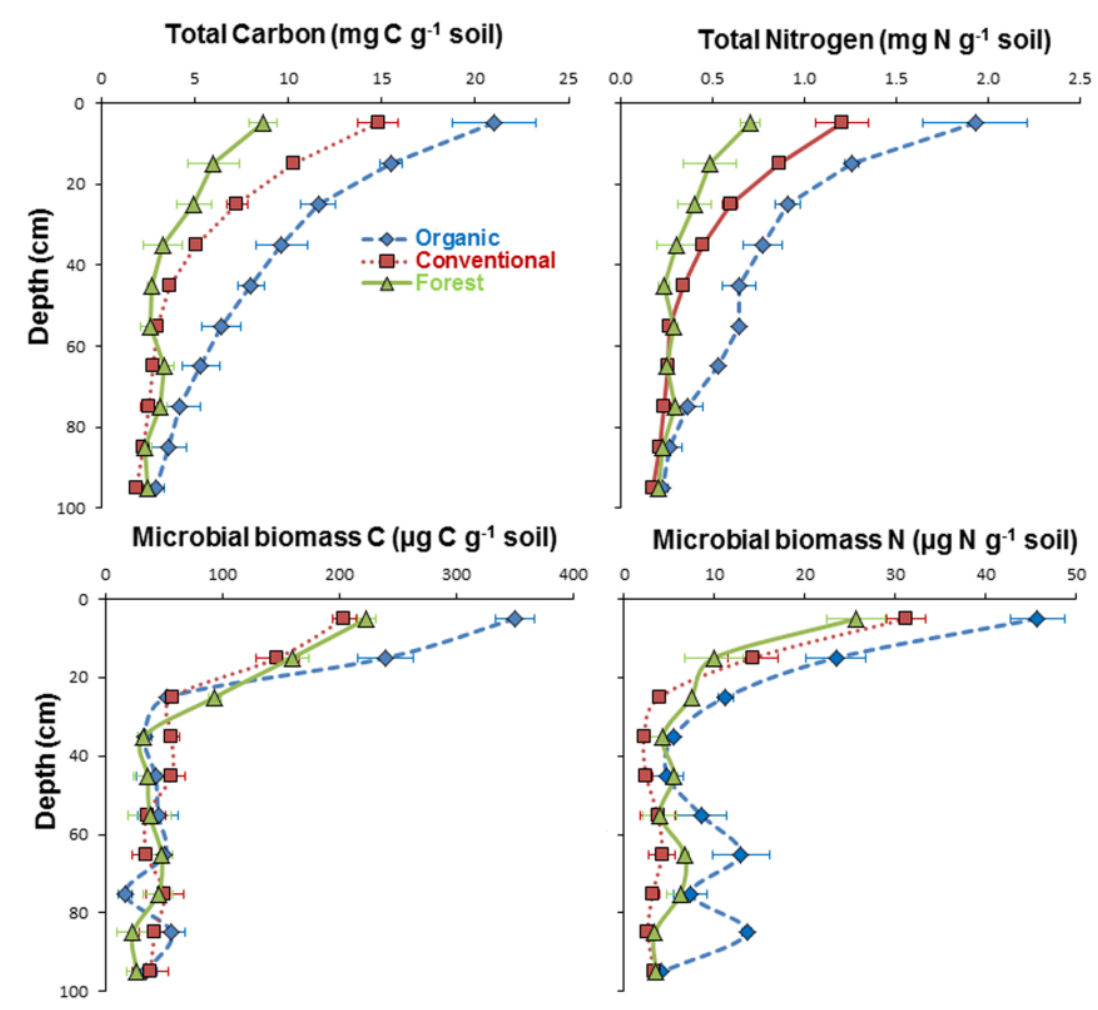

Figure S3. Total $\mathrm{C}, \mathrm{N}$, and microbial biomass $\mathrm{C}$ and $\mathrm{N}$ depending on land use and depth. Values represent means $\pm S E(n=3)$. 


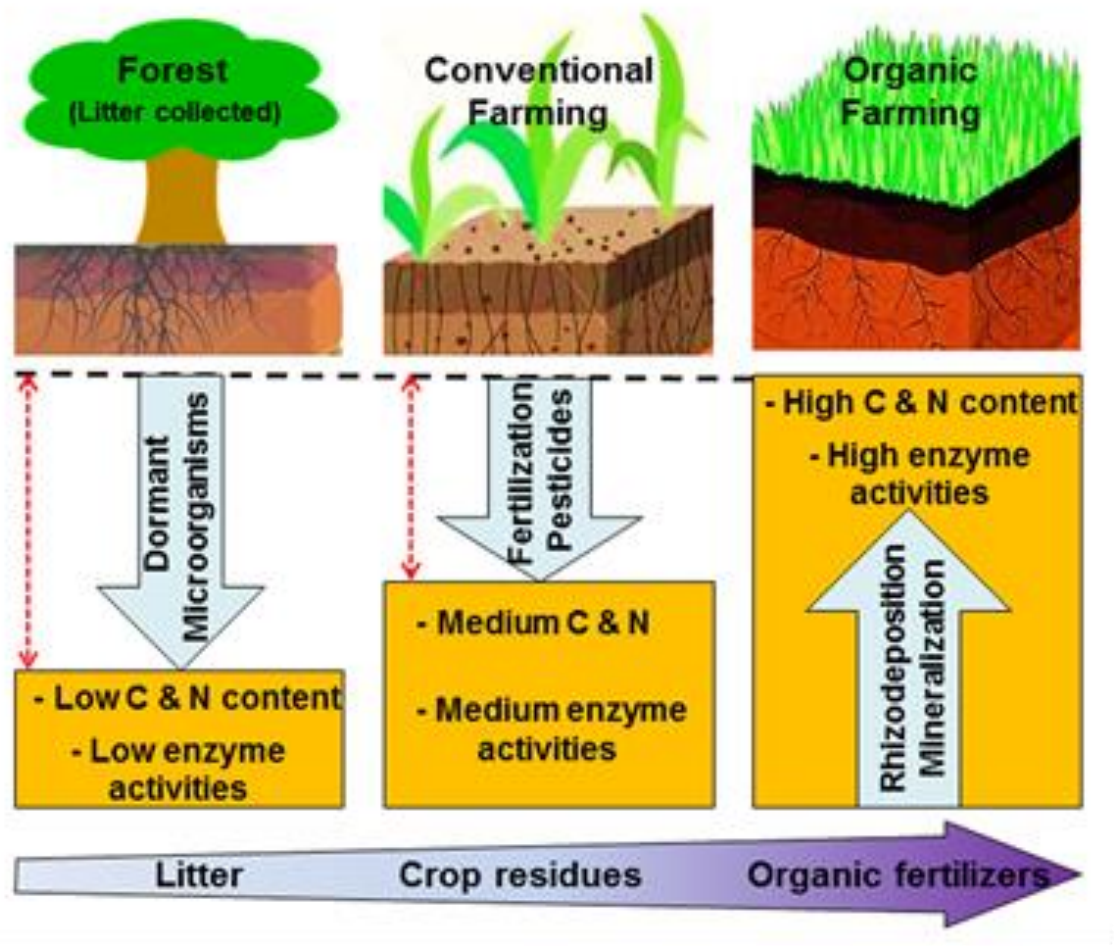

Figure S4. The effect of land use on carbon and nitrogen content in soil along with enzyme activities under different land use systems.

\subsubsection{Land-use type effects $P$ availability}

Total $\mathrm{Pi}$ constituted between $58 \%$ and $82 \%$ of total $\mathrm{P}$. Total $\mathrm{Pi}, \mathrm{Po}$, and $\mathrm{P}$ stocks were higher in organic farming than conventional farming and forest, and declined with depth in all soils (Fig. S5). Easily-available $\mathrm{P}$ fractions (microbial biomass $\mathrm{P}, \mathrm{NaHCO}_{3}-\mathrm{Pi}$ and $\mathrm{Po}$ ), moderately available $\mathrm{P}(\mathrm{NaOH}-\mathrm{Po})$ and non-available $\mathrm{P}(\mathrm{HCl}-\mathrm{Pi}$ and $\mathrm{Po}$ ) were much higher in organic farming than conventional farming and forest, especially in the topsoil layer. 

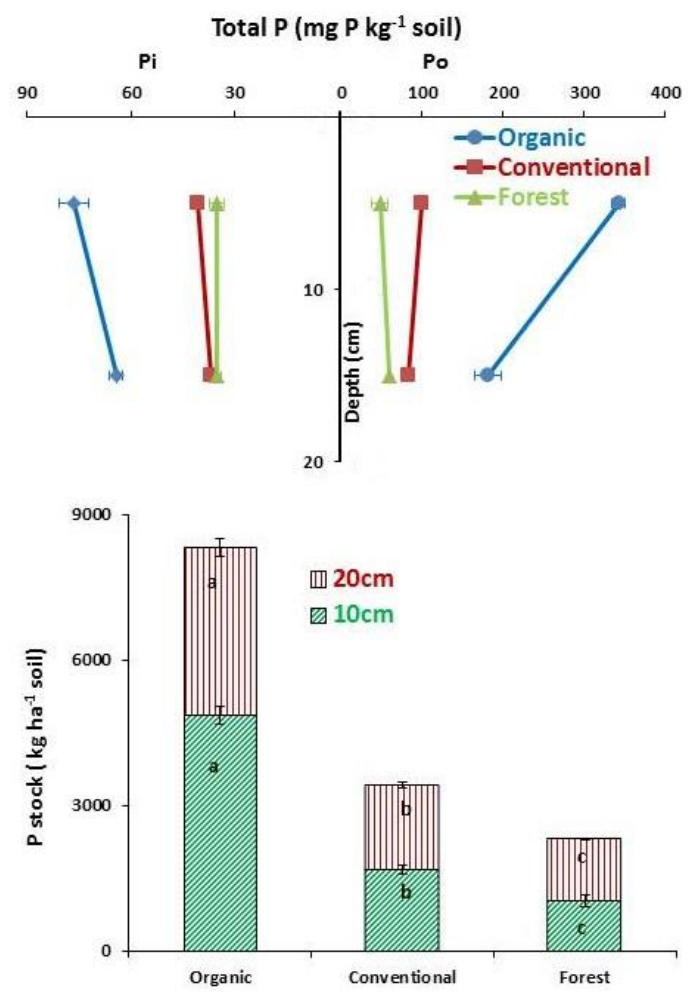

Figure S5 Total content of organic and inorganic $\mathrm{P}\left(\mathrm{mg} \mathrm{P} \mathrm{kg}^{-1}\right)$ (top) and $\mathrm{P}$ stocks $\left(\mathrm{kg} \mathrm{P} \mathrm{ha}^{-1}\right)$ (bottom) depending on land use. Values represent means $\pm \operatorname{SE}(n=4)$. Means followed by different letters within the same depth differ significantly $(p<0.05)$.

The higher C: Po ratio $(>100)$ in conventional farming and forest than organic farming indicates $P$ limitations in these land use system. Thus, mineralization of $P o$ is enhanced to release mineral $\mathrm{P}$, corresponding with the higher activity of acid phosphatase in conventional farming and forest (Fig.S6).
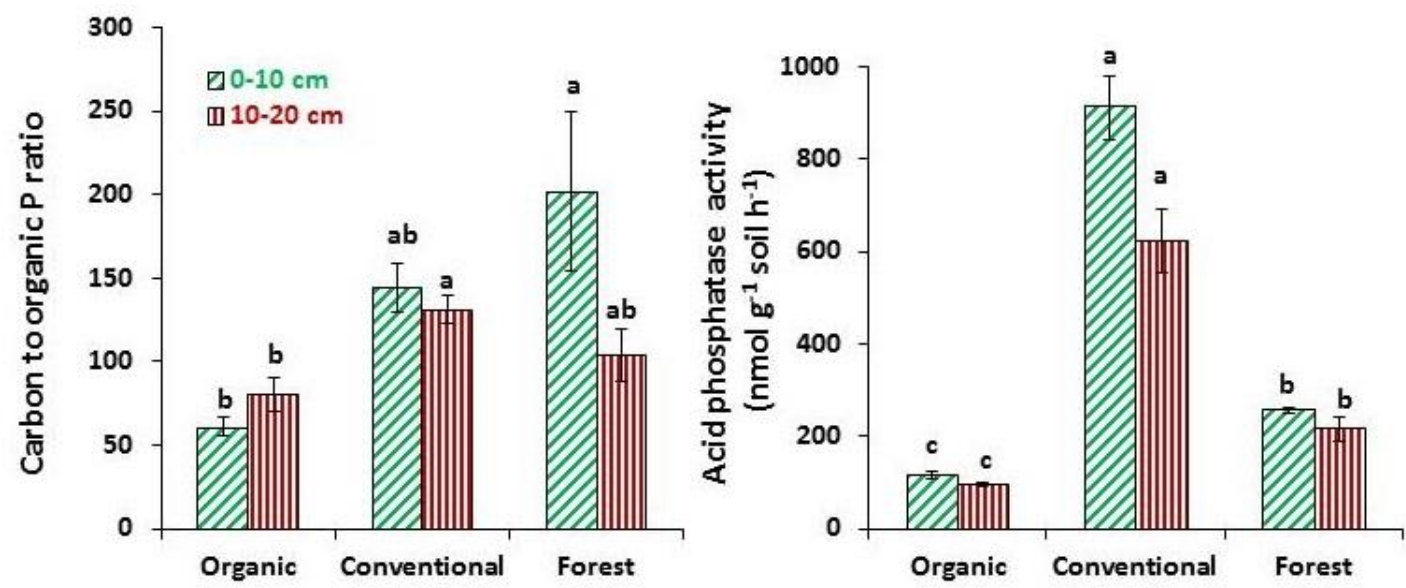

Figure S6 Ratio of soil carbon to organic phosphorus and acid phosphatase activity ( $\mathrm{nmol} \mathrm{g}^{-1}$ soil $\mathrm{h}^{\text {- }}$ $\left.{ }^{1}\right)$ depending on land use. Values represent means \pm SE $(n=4)$. Means followed by different letters within the same depth differ significantly $(p<0.05)$. 
Organic matter input, i.e., farmyard manure, crop rotation, and incorporation of residue, are the key factors responsible for the high $\mathrm{P}$ content under organic farming than other land use systems. The larger fraction of organic $P(P o)$ than inorganic $P(P i)$ implies that total $P$ is regulated by organic $\mathrm{P}$ in all three land use systems (Fig S7).

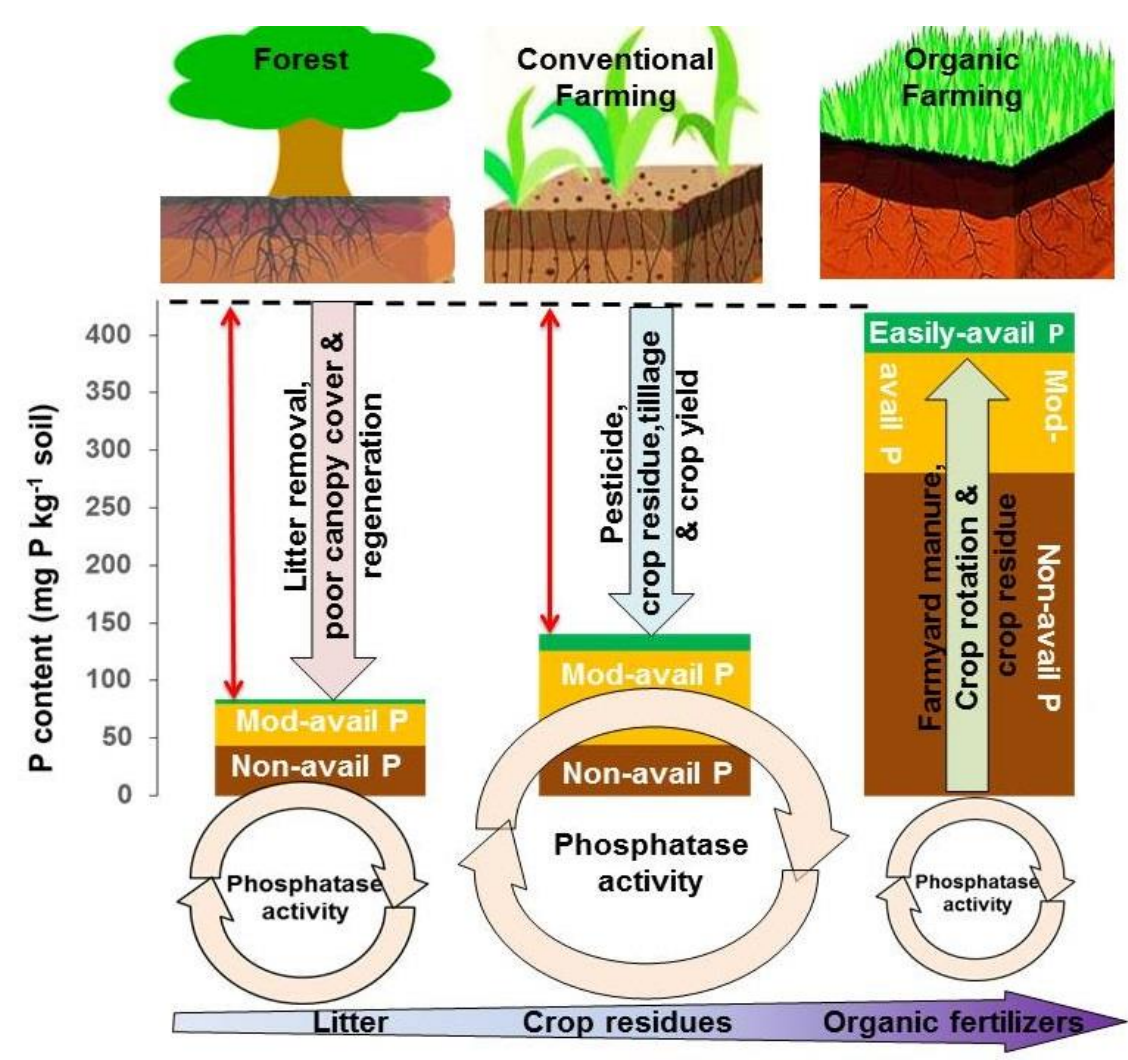

Figure S7 Conceptual diagram representing the effects of land use on soil phosphorus. Colors: green=easily-available phosphorus, yellow=moderately-available phosphorus, brown $=$ non-available phosphorus. Olive color upward arrow represents factors contribution for increasing different fractions of phosphorus in soil under organic farming. Light blue and light pink downward arrows indicates factors responsible for decreasing different fractions of phosphorus in soil under conventional farming and forest, respectively. The double circle arrows (peach color) indicate the phosphate activity. Color intensity of horizontal arrow i.e. light to dark purple represents the lower to higher status of phosphorus stock in soil under forest conventional farming and organic farming. Litter, crop residue and organic fertilizers are dominant factor controlling the soil phosphorus stock in forest, conventional farming and organic farming, respectively. Red line (-) shows P losses after land-use change.

\subsubsection{Microbial respiratory response to addition of nutrients with glucose}

Addition of $\mathrm{C}$ alone increased cumulative $\mathrm{CO}_{2}$ emissions (by 33\%), i.e., initiated a positive PE, while reducing microbial biomass (by 16\%) in soil under organic farming (Fig.S8 and S9, study 3). Additionally, results from substrate-induced respiration demonstrating higher 
specific growth rates $\left(\mu \mathrm{m}, 0.48 \mathrm{~h}^{-1}\right)$ and short lag times $(5 \mathrm{~h})$ reveals the relative dominance of fast growing r-strategists under starvation conditions in soil under organic farming (Fig.S10, study 4). Conversely, the similar $\mu \mathrm{m}$ but longer lag times (15 $\mathrm{h}$ and $25 \mathrm{~h}$ in soil under conventional and forest, respectively) indicates the dominancy of different strategists under starvation conditions, with K-strategists (slow growing) dominant under convention farming and L-strategists (stress tolerant) dominating under forest. Thus, it is reasonable to conclude that $r$-strategists reduce their biomass through autolysis instead of maintaining their populations under unfavorable conditions. This results in the production of necromass, which can serve as a substrate for the remaining surviving microorganisms, thus contributing to the positive PE in soil under organic farming. However, $\mathrm{K}$ and L- strategists maintain their biomass under unfavorable conditions (Fig.S10, study 4), corresponding with the stable microbial biomass and relatively low PE noted in conventional farming and forest soils, respectively (Fig.S8 and S9, study 3).

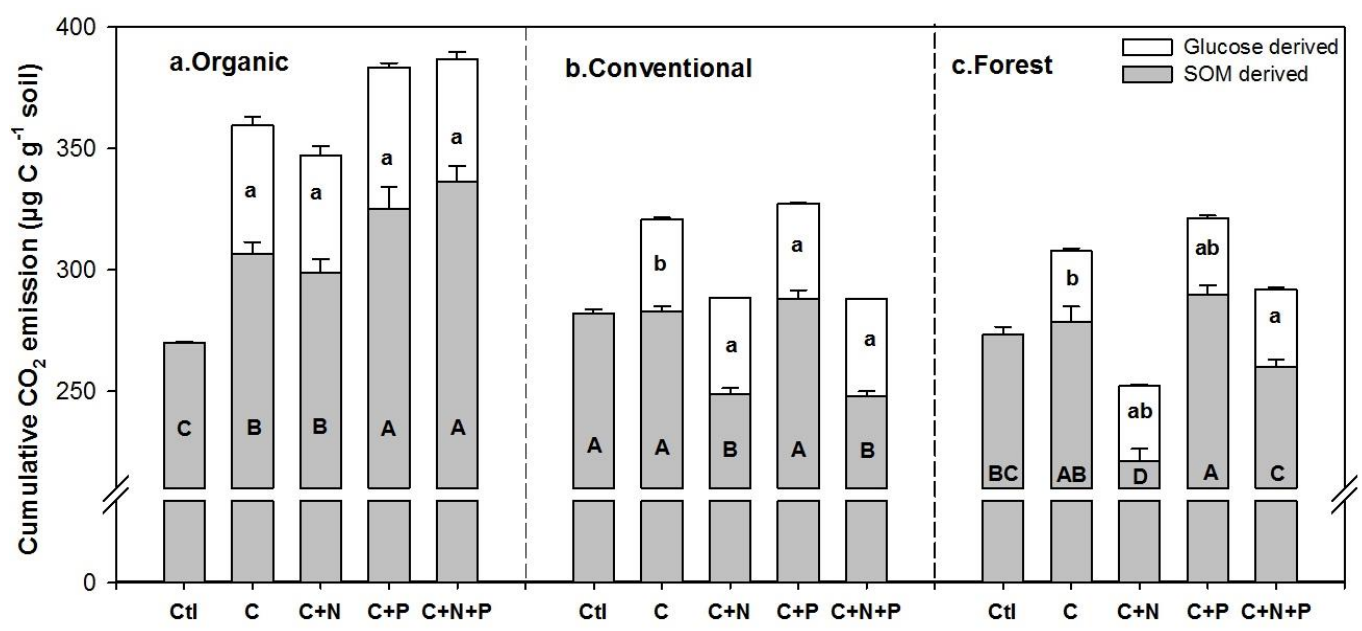

Figure S8 Cumulative priming over 45 days of incubation period and cumulative $\mathrm{CO}_{2}$ emission at 45 days in soil under organic farming, conventional farming, and forest. Add dotted line indication PE and letters of significance to the bars. Values are means \pm standard error $(n=4)$. 


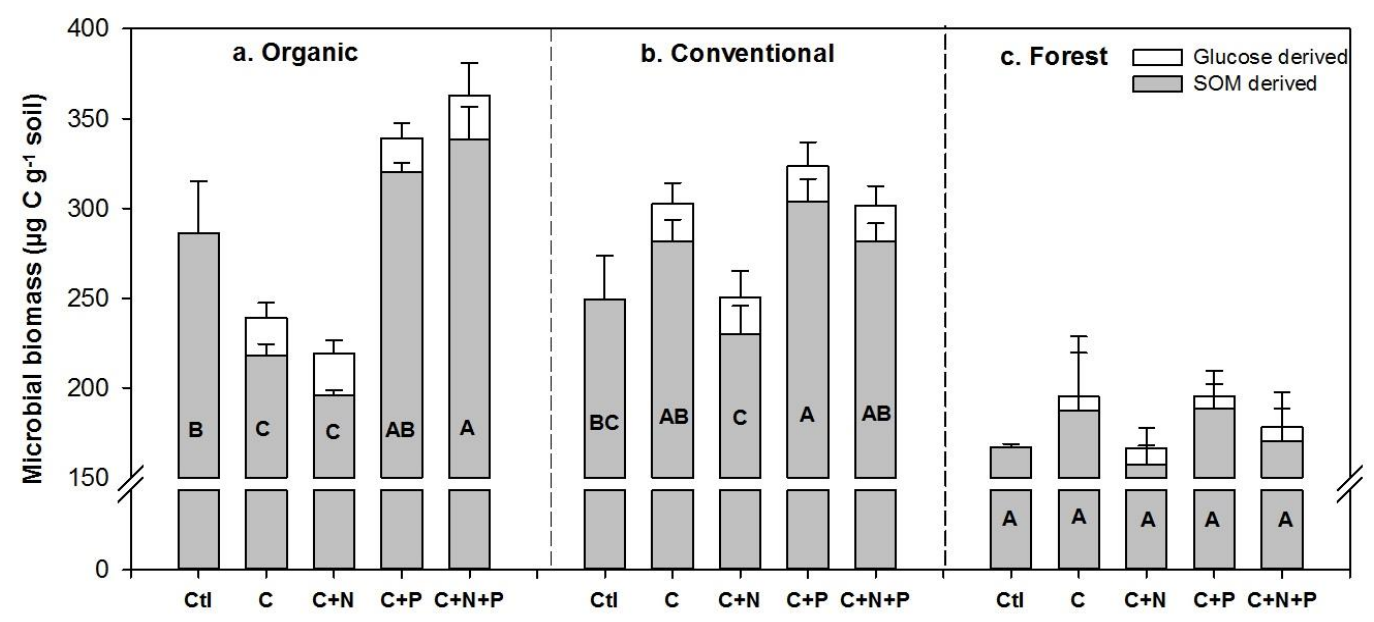

Figure S9 Microbial biomass derived from soil organic matter and from added glucose in soil under organic farming (a), conventional farming, (b) and forest (c) at the end of incubation. Control, C, $\mathrm{C}+\mathrm{N}, \mathrm{C}+\mathrm{P}$, and $\mathrm{C}+\mathrm{N}+\mathrm{P}$ in the figure represent the addition of water, glucose only, glucose + nitrogen, glucose + phosphorus, glucose + nitrogen + phosphorus, respectively. Values are means \pm standard error $(n=4)$.

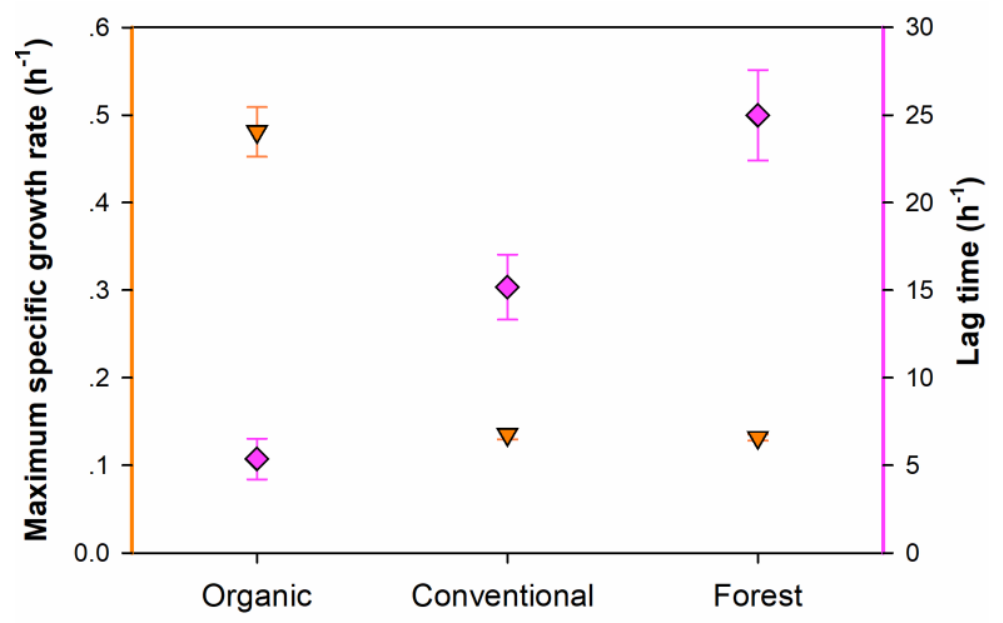

Figure S10 Maximum specific growth rate and lag time in soil under different land use system. Values are means \pm standard error $(n=3)$.

$\mathrm{N}$ addition with $\mathrm{C}$ reduced SOM decomposition, i.e., induced a negative PE (33 and $52 \mu \mathrm{g}$ $\mathrm{C} \mathrm{g}^{-1}$ respectively) in soil under conventional farming and forest, supporting the preferential microbial substrate utilization theory. This implies that microorganisms prefer to utilize added $\mathrm{C}$ and $\mathrm{N}$ instead of decomposing SOM to fulfill their energy and nutrient requirements (Fig.S8). In contrast to the suppressive effects of $\mathrm{N}, \mathrm{P}$ addition in combination with $C$ enhanced (up to $42 \%$ ) microbial respiration across all land use type. This could be attributed to the increased microbial biomass concentration and the resultant increases in $\mathrm{N}$ demand (Fig.S8). 
Similar to $\mathrm{N}$ addition, $\mathrm{C}$ with multiple nutrient $(\mathrm{N}+\mathrm{P})$ addition decreased the decomposition of SOM, leading to negative PE (35 and $13 \mu \mathrm{g} \mathrm{C} \mathrm{g}^{-1}$ respectively) in soil under conventional farming and forest. However, microbial biomass was stable, indicating that active microbial biomass, rather than total microbial biomass, drives soil respiratory rates. Furthermore, addition of $\mathrm{N}$ shifts microbial community structure by increasing the growth of bacterial grazing protozoans, which reduces decomposition rates in these land use systems. In contrast, the enhanced decomposition of SOM corresponded with increases in microbial biomass (by 18\%) with the combined addition of $\mathrm{N}$ and $\mathrm{P}$ in soil under organic farming. Addition of further nutrients to nutrient rich organic soil stimulates microorganisms and enhances SOM decomposition to fulfill their increased metabolic requirements (Fig.S8 and S9). Overall, SOM decomposition is dependent on the availability of essential nutrients under different land use systems.

\subsubsection{Road to sustainability}

Crop yield has been significantly increased through conventional agriculture for supporting the livelihood of rising population (Stockdale et al., 2002). However, global concern is growing the effect of intensive agriculture on long-term soil fertility (Allen-Stevens 1999), due to reductions in soil organic matte content. It has been suggested that organic farming is realistic alternative approach which provide both agronomic and environmental benefits, especially improving soil quality (Stockdale et al., 2001).

Conversion of forest to organic and conventional farming significantly alters the soil and microbial properties. Between two agroecosystems, regular application of farmyard manure under organic farming supplies available $\mathrm{N}$ and $\mathrm{P}$ for plant growth, resulting in higher plant biomass with organic farming (Mäder et al., 2002). Consequently, the higher incorporation of crop residues in organic farming results in higher levels of organic matter deposition for C (1.4 fold), N (1.5 fold), and Total P (by 3 fold) compared with conventional farming (Stockdale et al., 2001). This provides favorable environments for microorganisms, contributing to enhanced microbial properties, i.e., biomass and enzyme activities (up to 3 fold higher than conventional farming); indicating higher soil fertility. Additionally, absence of pesticide use and application of organic fertilizers supports diverse active microbial communities which efficiently utilize the resources (Mäder et al., 2002). A combination of higher microbial activity and fertility supports the production of high yield and good quality crops (Mäder et al., 2002). Previous study showed that organic farming produces high quality wheat yield in the long period of time with less application of fertilizers and plant 
protection agents (Mäder et al., 2007).Thus, organic farming practices can solve the problem of hunger as well as soil degradation.

With the rapid increase of the human population, increasing global food production while conserving biodiversity and native environments are pillars of "sustainable development." However, achieving these two needs is a challenging task for agricultural and environmental scientists in the $21^{\text {st }}$ century (Tscharntke et al., 2012; Maston et al., 1997). The development of ecologically-based land use and management practices can contribute to meeting these challenges by linking sustainable agriculture production with biodiversity conservation. The organic based land use management approach, i.e., the use of organic based fertilizers and pesticides, are receiving global attention. Such approaches are pathways to sustainable agriculture production and reduction of off-site problems. The successful implementation of such strategies will require the contribution from different stakeholders, i.e., scientists, national and international agricultural research institutions, industry, policymakers, and farmers (Maston et al., 1997).

\subsection{Conclusions}

Land-use change from natural ecosystem to agricultural land has severe impacts on soil quality. Various management practices under organic farming, i.e. application of farmyard manure, vermicomposting, incorporation of crop residue, and various cropping systems, lead to an increase in SOM and provide favorable environments for microorganisms. Consequently, this leads to improvements to soil properties (organic $\mathrm{C}$, total $\mathrm{N}$, total $\mathrm{P}$ ) and microbial properties (microbial biomass $\mathrm{C}, \mathrm{N}, \mathrm{P}$ and enzyme activities except xylanase and acid phosphatase), with organic farming, particularly in the topsoil. Microbial biomass, the living component of SOM, plays a crucial role in determining the physical, chemical and biological properties of soil. Hence, microbial biomass and enzyme activities are considered as potential indicators of soil fertility and soil quality. Application of local organic fertilizers (farmyard manure and animal manure), and elimination of pesticides reduce production costs for farmers while improving soil and crop quality, improving economic, ecological and human health outcomes. Additionally, the cultivation of diverse crops in organic farming systems provides diverse food products, improving food security and ultimately helping to reduce poverty.

Globally, application of fertilizers ( $\mathrm{N}$ or $\mathrm{P}$ or $\mathrm{N}+\mathrm{P}$ ) is the most common anthropogenic practice to increase crop yield. This leads to changes in the global carbon cycle, as decomposition of native SOM is affected by addition of glucose and nutrients. In soil under 
organic farming, formation of microbial necromass from fast-growing r-strategist microorganisms under starvation conditions contributes to increase decomposition rates, i.e., induces positive PE, with addition of ${ }^{14} \mathrm{C}$ labelled glucose only. In contrast, slow growing $\mathrm{K}$ - and stress tolerant $\mathrm{L}$ - strategists were responsible for the relatively low decomposition rates in soils under conventional farming and forest, respectively. This shows PE is determined by variations in the microbial growth strategies under different land use systems. Furthermore, addition of $\mathrm{N}$ with $\mathrm{C}$ strongly suppressed SOM decomposition processes in soils under conventional farming and forests, supporting the theory of preferential microbial substrate utilization, while addition of $\mathrm{P}$ with $\mathrm{C}$ accelerated decomposition of SOM in all lands use systems due to microbial mining of SOM to fulfill the increased demand for $\mathrm{N}$. The interaction of multiple nutrients ( $\mathrm{N}$ and $\mathrm{P}$ ) showed divergent effect on decomposition processes in the different land use systems. Similar to $\mathrm{N}$ addition, decomposition of SOM was suppressed in nutrient limited soil under conventional farming and forest, indicating that the decomposition process responded more to $\mathrm{N}$ than to $\mathrm{P}$ addition. In contrast, decomposition was enhanced in soil under organic farming after multiple nutrients addition, corresponding with an increase in microbial biomass of $18 \%$. Thus, decomposition of SOM increased to fulfil the metabolic requirements of an increased microbial population, resulting in a strong positive PE. Addition of multiple nutrients stimulated microorganism and enhanced soil organic matter decomposition to fulfill their nutrients demand, leading to positive priming in soil under organic farming. After addition of all nutrient combinations except $\mathrm{P}$, the decomposition of SOM decreased while microbial biomass remained stable in conventional farming soil. However, this could be the short term microbial response to nutrient addition. In long term fertilization under intensive agriculture, microbial response to nutrient addition might change, potentially affecting the decomposition process.

In modern conventional farming systems, farmers apply excessive mineral fertilizers to increase crop yields. Additionally, mineral fertilizers tend to leach away, necessitating repeated applications. This leads to the accumulation of toxic chemicals, adversely affecting microbial biomass and enzyme activities. Consequently, the decline of soil fertility leads to decreases in plant biomass. This leads to reductions in incorporation of crop residue, consequently, decreasing in the quality and quantity of SOM, ultimately reducing carbon sequestration. In organic farming, higher plant biomass due to farmyard manure leads to increase incorporation of higher crop residue, consequently increasing soil organic matter which enhanced microbial activity. Thus, microorganism decomposes soil organic matter to release nutrients, indicating higher soil fertility in organic farming. However, increased decomposition of soil organic matter leads to increase soil respiration. Beside, 
carbon sequestration is balance between how much input of $C$ and how much out of $C$ out to ecosystem (Janzen, 2006). In organic farming, C input is much higher than conventional farming and forest. Thus, organic farming still has more potential to enhance carbon sequestration than other two land use systems (Janzen, 2006).

Although belonging to agroecosystems, organic farming promotes sustainability by enhancing economic, social, and environmental benefits, i.e., increasing crop yield, reducing poverty through food security, and increasing soil fertility and carbon sequestration, respectively. It is therefore rational to conclude that organic farming is a more sustainable agricultural production system.

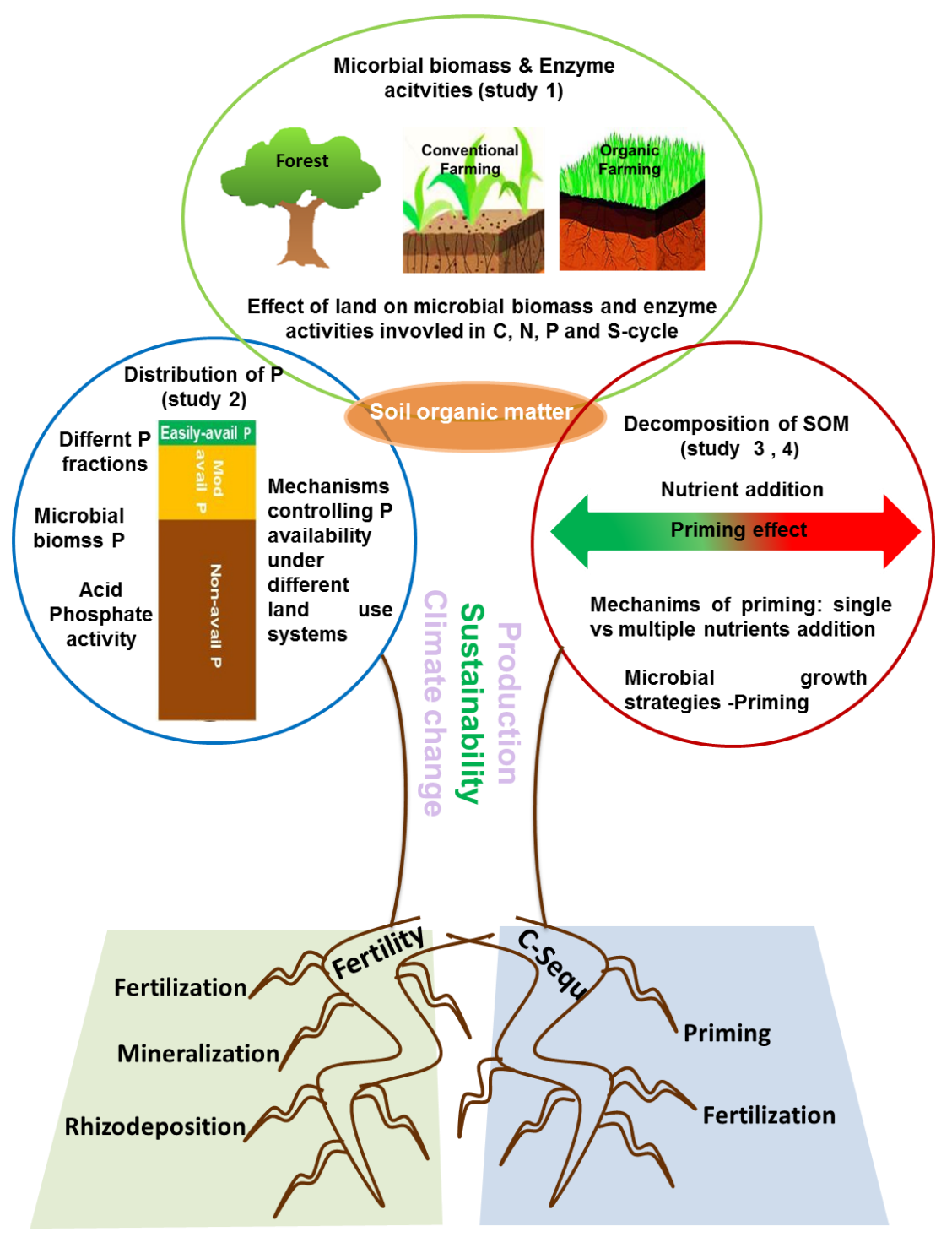

Figure S11 Synthesis of the main results. Effect of land use on soil fertility, and carbon sequestration. SOM- soil organic matter. C-Sequ-carbon sequestration 


\subsection{References}

Anderson, J.P.E., Domsch, K.H., 1978. A physiological method for the quantitative measurement of microbial biomass in soils. Soil Biol. Biochem. 10, 215-221.

Allen-Stevens, T., 1999. Going right back to your roots. Crops 17, 12-13.

Bellamy, P.H., Loveland, P.J., Bradley, R.I., Lark, R.M., Kirk, G.J.D., 2005. Carbon losses from all soils across England and Wales 1978-2003. Nature 437, 245-248.

Blagodatskaya, E., Khomyakov, N., Myachina, O., Bogomolova, I., Blagodatsky, S., Kuzyakov, Y., 2014. Microbial interactions affect sources of priming induced by cellulose. Soil Biol. Biochem. 74, 39-49. doi:10.1016/j.soilbio.2014.02.017

Blagodatskaya, E., Kuzyakov, Y., 2008. Mechanisms of real and apparent priming effects and their dependence on soil microbial biomass and community structure: critical review. Biol. Fertil. Soils 45, 115-131.

Blagodatskaya, E.V., Blagodatsky, S.A., Anderson, T.-H., Kuzyakov, Y., 2007. Priming effects in Chernozem induced by glucose and $\mathrm{N}$ in relation to microbial growth strategies. Appl. Soil Ecol. 37, 95-105.

Blagodatsky, S.A., Heinemeyer, O., Richter, J., 2000. Estimating the active and total soil microbial biomass by kinetic respiration analysis. Biol. Fertil. Soils 32, 73-81.

Burney, J. A, Davis, S.J., Lobell, D.B., 2010.Greenhouse gas mitigation by agricultural intensification. PNAS 107, 12052-12057.

Chen, R., Senbayram, M., Blagodatsky, S., Myachina, O., Dittert, K., Lin, X., Blagodatskaya, E., Kuzyakov, Y., 2014. Soil $\mathrm{C}$ and $\mathrm{N}$ availability determine the priming effect: Microbial $\mathrm{N}$ mining and stoichiometric decomposition theories. Glob. Chang. Biol. 20, 2356-2367.

Cheesman A.W., Turner B.L., Reddy, K.., 2010. Interaction of phosphorus compounds with anionexchange membranes: implications for soil analysis. Soil Sci. Soc. Am. J. 74, 1607-1612.

Clarholm, M., 1985. Interactions of bacteria, protozoa and plants leading to mineralization of soil nitrogen. Soil Biol. Biochem. 17, 181-187. doi:10.1016/0038-0717(85)90113-0

Cleveland, C.C., Townsend, A.R., 2006. Nutrient additions to a tropical rain forest drive substantial soil carbon dioxide losses to the atmosphere. Proc. Natl. Acad. Sci. U. S. A. 103, 1031610321

Cleveland, C.C., Townsend, A.R., Schmidt, S.K., 2002. Phosphorus Limitation of Microbial Processes in Moist Tropical Forests: Evidence from Short-term Laboratory Incubations and Field Studies. Ecosystems 5, 0680-0691.

De Deyn, G.B., Cornelissen, J.H.C., Bardgett, R.D., 2008. Plant functional traits and soil carbon sequestration in contrasting biomes. Ecol. Lett. 11: 516-531.

Dick, R.P., Breakwill, D., Turco, R., 1996. Soil enzyme activities and biodiversity measurements as integrating biological indicators. In: Doran, J.W., Jones, A.J. (Eds. . (Ed.), Handbook of Methods for Assessment of Soil Quality. Soil Sci. Soc. Am., Madison, pp. 247-272.

Dirzo, R., Raven, P.H., 2003.Global state of biodiversit and loss. Annu. Rev. Environ. Resour. 28, 137-167. Fisk, M., Santangelo, S., Minick, K., 2015. Carbon mineralization is promoted by phosphorus and reduced by nitrogen addition in the organic horizon of northern hardwood forests. Soil Biol. Biochem. 81, 212-218.

Eivazi, F., Tabatabai, M.A., 1977. Phosphatases in soils. Soil Biol Biochem 9, 167-172

Foley, J.A., Ramankutty, N., Brauman, K.A., Cassidy, E.S., Gerber, J.S., Johnston, M., Mueller, N.D., O'Connell, C., Ray, D.K., West, P.C., Balzer, C., Bennett, E.M., Carpenter, S.R., Hill, J., Monfreda, C., Polasky, S., Rockström, J., Sheehan, J., Siebert, S., Tilman, D., Zaks, D.P.M., 2011. Solutions for a cultivated planet. Nature 478, 337-342.

Fontaine, S., Mariotti, A., Abbadie, L., 2003. The priming effect of organic matter: A question of microbial competition? Soil Biol. Biochem. 35, 837-843

Fornara, D.A., Banin, L., Crawley, M.J., 2013. Multi-nutrient vs. nitrogen-only effects on carbon sequestration in grassland soils. Glob. Chang. Biol. 19, 3848-3857.

FRA/DFRS, 2014. Terai Forests of Nepal (2010-2012). Babarmahal, Kathmandu: Forest Resources Assessment Nepal Project/Department of Forest Research and Survey.

Geissen, V., Sánchez-hernández, R., Kampichler, C., Ramos-reyes, R., Sepulveda-lozada, A., 2009. Geoderma Effects of land-use change on some properties of tropical soils - An example from Southeast Mexico. Geoderma 151, 87-97.

German, D.P., Chacon, S.S., Allison, S.D., 2011. Substrate concentration and enzyme allocation can affect rates of microbial decomposition. Ecology 92, 1471-1480.

Gilmullina, A., Blagodatskaya, E.V., Kuzyakov, Y., 2017. Protocol to soil respiration measurement by RABIT. Soil Science Department, University of Goettingen, Germany 
Guillaume, T., 2015.Effects of rainforest transformation systems on carbon cycle and soil fertility.PhD. thesis, University of Goettingen, Germany.

Guillaume, T.,Damris, M., Kuzyakov, Y., 2015. Losses of soil carbon by converting tropical forest to plantations: Erosion and decomposition estimated by $\delta^{13} \mathrm{C}$. Glob. Chang. Biol. 21, 35483560.

Hamid, R., Khan, M., Ahmad, M., Ahmad, M., Abdin, M., Musarrat, J., Javed, S., 2013. Chitinases: an update. J Pharm Bioallied Sci 21-29.

Hedley, M.J., Stewart, J.W.B., Chauhan, B.S., 1982. Changes inorganic and organic soil phosphorus fractions induced by cultivation practices and by laboratory incubations. Soil Sci. Soc. Am. J. 46, 970-976.

Hoang, D.T.T., Pausch, J., Razavi, B.S., Kuzyakova, I., Banfield, C.C., Kuzyakov, Y., 2016. Hotspots of microbial activity induced by earthworm burrows, old root channels, and their combination in subsoil. Biol. Fertil.

Houghton, R., 2012. Historic changes in terrestrial carbon storage. In: Lal, R., Lorenz, K.,Hüttl R, F., Schneid er, B.U., von Braun, J. (Eds.), Recarbonization of the Biosphere. Springer, pp. S. 59-S. 82.

IUSS Working Group WRB, 2015. World Reference Base for Soil Resources for 2014. World Soil Resources Report No. 106. FAO, Rome, 203 pp.

Janssens, I.A., Dieleman, W., Luyssaert, S., Subke, J.-A., Reichstein, M., Ceulemans, R., Ciais, P., Dolman, A.J., Grace, J., Matteucci, G., Papale, D., Piao, S.L., Schulze, E.-D., Tang, J., Law, B.E., 2010. Reduction of forest soil respiration in response to nitrogen deposition. Nat. Geosci. $3,315-322$

Janzen, H.H., 2006. The soil dilemma:Shall we hoard it or use it ? Soil Biol. Biochem. 35, 837-843

Jobbágy, E.G., Jackson, R.B., 2000. The vertical distribution of soil organic carbon and its relation to climate and vegetation. Ecol. Appl. 10, 423-436.

Karlen, D.L., Mausbach, M.J., Doran, J.W., Cline, R.G., Harris, R.F., Schuman, G.E., 1997. Soil quality: a concept, definition, and framework for evaluation. Soil Sci. Soc. Am 61, 4-10.

Koch, O., Tscherko, D., Kandeler, E., 2007. Temperature sensitivity of microbial respiration, nitrogen mineralization, and potential soil enzyme activities in organic alpine soils. Global Biogeochem. Cycles 21, 1-11.

Klose, S., Tabatabai, M.A., 2002. Response of phosphomonoesterases in soils to chloroform fumigation. J. Plant Nutr. Soil Sci. 165, 429-434.

Kouno, K., Tuchiya, Y., Ando, T., 1995. Measurement of soil microbial biomass phosphorus by an anion exchange membrane method. Sbb 27, 1353-1357.

Kutsch, W.L., Aubinet, M., Buchmann, N., Smith, P., Osborne, B., Eugster, W., Wattenbach, M., Schrumpf, M., Schulze, E.D., Tomelleri, E., Ceschia, E., Bernhofer, C., Béziat, P., Carrara, A., Di Tommasi, P., Grünwald, T., Jones, M., Magliulo, V., Marloie, O., Moureaux, C., Olioso, A., Sanz, M.J., Saunders, M., Søgaard, H., Ziegler, W., 2010. The net biome production of full crop rotations in Europe. Agric. Ecosyst. Environ. 139, 336-345.

Kuzyakov, Y., 2010. Priming effects: Interactions between living and dead organic matter. Soil Biol. Biochem. 42, 1363-1371. Lal, R., 2006. Enhancing crop yields in the developing countries through restoration of the soil organic carbon pool in agricultural lands. L. Degrad. Dev. 17, 197-209

Lal, R., 2004. Soil Carbon Sequestration Impacts on Global Climate Change and Food Security. Science (80-.). 304, 1623-1627.

Lambin, E.F., Geist, H.J., Lepers, E., 2003. Dynamics of land-use and land-cover change in tropical regions. Annu. Rev. Environ. Resour. 28, 205-241.

Lambin, E.F., Meyfroidt, P., 2011. Global land use change, economic globalization, and the looming land scarcity. Proc. Natl. Acad. Sci. U. S. A. 108, 3465-72.

Lasco RD, Ogle S, Raison J, Verchot L, Wassmann R, Yagi K (2006) Volume 4: Agriculture, Forestry and Other Land Use. In: IPCC Guidelines for National Greenhouse Gas Inventories, Vol. 4, pp. 1-66.

Liang, Q., Chen, H., Gong, Y., Yang, H., Fan, M., Kuzyakov, Y., 2014. Effects of 15 years of manure and inorganic fertilizers on enzyme activities in particle-size fractions in a North China Plain soil. Eur J. Soil Biol. 60: 112-119.

Liu, L., Greaver, T.L., 2010. A global perspective on belowground carbon dynamics under nitrogen enrichment. Ecol. Lett. 13, 819-828.

MA, 2005. The Millennium Ecosystem Assessment and Human Well-Being: Synthesis. Island Press, Washistong, DC. 
Mäeder, P., Fliessbach, A., Dubois, D., Gunst, L., Fried, P., Niggli, U., 2002. Soil fertility and biodiversity in organic farming. Science (80-). 31, 1694-1697.

Mäeder, P., Hahn, D., Dubois, D., Gunst, L., Alföldi, T., Bergmann, H., Oehme, M., Amado, R., Schneider, H., Graf, Ursula., Velimirov, A., Fliessbach, A., Niggli, U., 2007Wheat quality in organic and conventional farming: results of a 21 year field experiment. J Sci Food Agric (87)., 1826-1835

Maharjan, M., Sanaullah, M., Razavi, B.S., Kuzyakov, Y., 2017. Effect of land use and management practices on microbial biomass and enzyme activities in subtropical top-and sub-soils. Appl. Soil Ecol. 113.

Malcom, R.E., 1983. Assessment of phosphatase activity in soils. Soil Biol. Biochem. 15, 403-408.

Maranguit, D., Guillaume, T., Kuzyakov, Y., 2017. Land-use change affects phosphorus fractions in highly weathered tropical soils. Catena 149, 385-393.

Matson, P.A., Parton, W.J., Power, A.G., Swift, M.J., 1997. Agricultural Intensification and Ecosystem Properties. Science (80). 277, 504-509.

Mganga, K.Z., 2015. Land-use effects on microbial biomass and carbon sequestration in tropical soils of Mount Kilimanjaro region. Ph.D thesis,University of Goettingen, Germany.

Mganga, K.Z., Razavi, B.S., Kuzyakov, Y., 2015. Microbial and enzymes response to nutrient additions in soils of Mt. Kilimanjaro region depending on land use. Eur. J. Soil Biol. 69, 33-40.

Nadelhoffer, K.J., Emmett, B.A., Gundersen, P., Kjùnaas, O.J., Koopmans, C.J., Schleppi, P., Tietema, A., Wright, R.F., 1999. Nitrogen deposition makes a minor contribution to carbon sequestration in temperate forests 398, 1997-2000.

Naylor, R.L., 1996. Energy and Resource Constraints on Intensive Agricultural Production. Annu. Rev. Energy Environ. 21, 99-123. Neufeldt, H., da Silva, J.E., Ayarza, M.A., Zech, W., 2000. Land-use effects on phosphorus fractions in Cerrado oxisols. Biol Fertil Soils 31, 30-37.

Poeplau, C.,Herrmann, A.M., Thomas, K., 2016.Opposing effects of nitrogen and phosphorus on soil microbial metabolism and the implications for soil carbon storage. Soil Biol. Biochem. 100, 8391.

Qiao, N., Xu, X., Hu, Y., Blagodatskaya, E., Liu, Y., Schaefer, D., Kuzyakov, Y., 2016. Carbon and nitrogen additions induce distinct priming effects along an organic-matter decay continuum. Sci. Rep. 6, 1-8.

Ramankutty, N., Foley, J. a., 1998.Characterizing patterns of global land use: An analysis of global croplands data. Global Biogeochem. Cycles 12, 667-685.

Rawlings, N.D., Fraser, R.M., Barrett, A.J., 2006. MEROPS: The peptidase database. Nucleic Acids Res. 27, 325-331.

Salazar-Villegas, A., Blagodatskaya, E., Dukes, J.S., 2016. Changes in the size of the active microbial pool explain short-term soil respiratory responses to temperature and moisture. Front. Microbiol. 7, 1-10. doi:10.3389/fmicb.2016.00524

Schlesinger, W.H., 1977. Carbon Balance in terrestrial detritus. Annu. Rev. Ecol. Syst. 8, 51-81.

Shahbaz, M., Kuzyakov, Y., Heitkamp, F., 2016. Decrease of soil organic matter stabilization with increasing inputs: Mechanisms and controls. Geoderma. 304,76-82

Skujins, J., 1976. Extracellular enzymes in soil. Crit. Rev. Microbiol 4, 383-421.

Six, J., Feller, C., Denef, K., Ogle, S.M., Sa, J.C.D., Albrecht, A., 2002. Soil organic matter, biota, and aggregation in temperate and tropical soils-effects of no-tillage. Agronomie 22, 755-775.

Smith, W.., Desjardins, R.., Pattey, E., 2000. The net flux of carbon from agricultural soils in Canada. Glob. Chang. Biol. 557-568.

Stevenson, J.R., Villoria, N., Byerlee, D., Kelley, T., Maredia, M., 2013. Green Revolution research saved an estimated 18 to 27 million hectares from being brought into agricultural production. Proc. Natl. Acad. Sci. 110, 8363-8368.

Stockdale, E.A., Shepherd M.A., Fortune, S., Cuttle, S.P., 2002. Soil fertility in organic farming systems-fundamentally different? Soil Use Manag. 18, 301-308.

Stockdale, E. a., Lampkin, N.H., Hovi, M., Keatinge, R., Lennartsson, E.K.M., Macdonald, D.W., Padel, S., Tattersall, F.H., Wolfe, M.S., Watson, C. a., 2001. Agronomic and environmental implications of organic farming systems. Adv. Agron. 70, 261-327.

Tiessen, H., Moir, J.O., 1993.Characterization of available $P$ by sequential extraction. In: Carter, M.R. (Ed. (Ed.), Soil Sampling and Methods of Analysis. Canadian Soc. Soil Sci., pp. 75-86.

Tilman, D., Fargione, J., Wolff, B., D'Antonio, C., Dobson, A., Howarth, R., Schindler, D., Schlesinger, W.H., Simberloff, D., Swackhamer, D., 2001. Forecasting agriculturally driven global environmental change. Science 292, 281-4.

Tilman, D., 1999. Global environmental impacts of agricultural expansion: The need for sustainable and efficient practices. Proc. Natl. Acad. Sci. 96, 5995-6000. 
Townsend, A.R., Braswell, B.H., Holland, E.A., Penner, J.E., 1996. Spatial and temporal patterns in terrestrial carbon storage due to deposition of fossil fuel nitrogen. Ecol. Appl 6, 806-814.

Tscharntke, T., Clough, Y., Wanger, T.C., Jackson, L., Motzke, I., Perfecto, I., Vandermeer, J., Whitbread, A., 2012. Global food security, biodiversity conservation and the future of agricultural intensification. Biol. Conserv. 151, 53-59.

Turner, B.L., Lambin, E.F., Reenberg, A., 2007. The emergence of land change science for global environmental change and sustainability. Proc. Natl. Acad. Sci. U. S. A. 104, $20666-71$.

van Noordwijk, M., Cerri, C., Woomer, P.L., Nugroho, K., Bernoux, M., 1997. Soil carbon dynamics in the humid tropical forest zone. Geoderma 79, 187-225.

Vance, E.D., Brookes, P.C., Jenkinson, D.S., 1987. An extraction method for measuring soil microbial biomass C. Soil Biol. Biochem. 19, 703-707.

Vitousek, P.M., Aber, J.D., Howarth, R.H., Likens, G.E., Matson, P.A., Schindler, D.W., Schlesinger, W.H., Tilman, D.G., 1997. Human alteration of the global nitrogen cycle: Source and consequences. Ecol Appl 7, 737-750.

Weaver, R.W., Angle, J.S., Bottomley, P.S., 1994. Methods of SoilAnalysis. Part 2. Microbiological and Biochemical Properties, No. 5. Soil Sci. Soc. Am., Madison.

Waldrop, M.P., Zak, D.R., 2006. Response of oxidative enzyme activities to nitrogen deposition affects soil concentrations of dissolved organic carbon. Ecosystems 9, 921-933.

West, T.., Post, W.., 2002. Soil Organic Carbon Sequestration Rates by Tillage and Crop Rotation: A Global Data Analysis. Soil Sci.Soc. Am.J. 66, 1930-1946.

Yevdokimov, I., Blagodatskaya, E., 2014. Determination of extractable and microbial P in soils with anion-exchange membranes. Goettingen, Germany.

\section{Web source:}

https://www.thinglink.com/scene/693071828536524800

http://manakamanagroup.com/chitwan-heritage/ 


\section{Contributions to the studies}

This $\mathrm{PhD}$ thesis comprises six studies which were successfully done in cooperation with several coauthors. The contributions of these coauthors are as follows:

\subsection{Study 1. Effect of land use and management practices on microbial biomass and enzyme activities in subtropical top-and sub-soils}

Status:

Menuka Maharjan:

Muhammad Sanaullah:

Bahar S. Razavi:

Yakov Kuzyakov:

\section{Published online in Applied Soil Ecology}

$60 \%$ (experimental design, accomplishment of experiment, laboratory analyses, data preparation and interpretation, manuscript preparation)

$10 \%$ (discussion of manuscript structure, comments to improve the manuscript)

$20 \%$ (laboratory analyses, discussion of manuscript structure; comments to improve the manuscript)

$10 \%$ (discussion of manuscript structure; comments to improve the manuscript)

\subsection{Study 2. Phosphorus fractions in subtropical soils depending on land use}

Status:

Menuka Maharjan:

Deejay Maranguit:

Yakov Kuzyakov:
Under review in European Journal of Soil Biology

$70 \%$ (experimental design, laboratory analyses analysis and interpretation of data; manuscript preparation)

$20 \%$ (laboratory analyses, interpretation of data, discussion of manuscript structure; comments to improve the manuscript)

$10 \%$ (discussion of manuscript structure; comments to improve the manuscript)

\subsection{Study 3. Nutrient availability regulates soil organic matter decomposition depending on land use}

Status:

Menuka Maharjan:

Huadong Zang:

Evgenia Blagodatskaya:

Yakov Kuzyakov:
In preparation

$70 \%$ (experimental design, laboratory analyses analysis and interpretation of data; manuscript preparation)

$20 \%$ (interpretation of data; discussion of manuscript structure; comments to improve the manuscript)

$10 \%$ (interpretation of data; discussion of manuscript structure; comments to improve the manuscript)

$10 \%$ (discussion of manuscript structure; comments to improve the manuscript) 


\subsection{Study 4. Microbial necromass as a source of priming regulated by microbial growth strategies}

Status:

In preparation

Menuka Maharjan:

$50 \%$ (soil sampling, experimental design, accomplishment of experiment, data preparation and interpretation, manuscript preparation)

Aliia Gilmullina:

$10 \%$ (laboratory analyses, analysis, and interpretation of data comments to improve the manuscript)

Huadong Zang:

$10 \%$ (laboratory analyses, analysis, and interpretation of data comments to improve the manuscript)

Yakov Kuzyakov:

$10 \%$ (experimental design, data interpretation, discussion of manuscript structure, comments to improve the manuscript)

Evgenia Blagodatskaya: $20 \%$ (experimental design, data analysis and interpretation, discussion of manuscript structure, comments to improve the manuscript)

\subsection{Study 5. Spatio-temporal patterns of enzyme activities after manure application reflect mechanisms of niche differentiation between plants and microorganisms}

Status:

Shibin Liu:

Bahar S. Razavi:

Xu Su:

Menuka Maharjan:

Mohsen Zarebanadkouki:

Evgenia Blagodatskaya:

Yakov Kuzyakov:

\section{Published online in Soil Biology and Biochemistry}

$50 \%$ (experimental design, accomplishment of experiment, data preparation and interpretation, manuscript preparation)

$10 \%$ (experimental design, laboratory analyses interpretation of data, comments to improve the manuscript)

$5 \%$ (comments to improve the manuscript)

$15 \%$ (laboratory analyses, analysis, and interpretation of data comments to improve the manuscript)

$10 \%$ (laboratory analyses, comments to improve the manuscript)

$5 \%$ (discussion of manuscript structure, comments to improve the manuscript)

$5 \%$ (discussion of manuscript structure, comments to improve the manuscript)

\subsection{Study 6. Effects of rhizosphere wettability on microbial biomass, enzyme activities, and localization}

Status:

Submitted to Journal Frontiers 
Katayoun Ahmadi:

Bahar S. Razavi:

Menuka Maharjan:

Yakov Kuzyakov:

Stanley J. Kostka:

Andrea Carminati:

Mohsen Zarebanadkouki:
$50 \%$ (experimental design, accomplishment of the experiment, data preparation and interpretation, manuscript preparation)

$10 \%$ (experimental design, accomplishment of the experiment, data preparation, and interpretation, comments to improve the manuscript)

$10 \%$ (laboratory analyses, analysis and interpretation of data; comments to improve the manuscript)

$5 \%$ (comments to improve the manuscript)

$5 \%$ (comments to improve the manuscript)

$10 \%$ (Discussion on experimental design; comments to improve the manuscript)

$10 \%$ (laboratory analyses; discussion on experimental design; comments to improve the manuscript) 


\section{Publications and Manuscripts}

\subsection{Study 1: Effect of land use and management practices on microbial biomass and enzyme activities in subtropical top-and sub-soils}

Menuka Maharian ${ }^{1,2^{*}}$, Muhammad Sanaullah ${ }^{1,3}$, Bahar S. Razavi ${ }^{4}$, Yakov Kuzyakov ${ }^{1,4}$

Status: Published in Journal of Applied Soil Ecology

${ }^{1}$ Department of Soil Science of Temperate Ecosystems, University of Göttingen,

Göttingen, Germany

${ }^{2}$ Institute of Forestry, Tribhuwan University, Hetauda, Makwanpur, Nepal

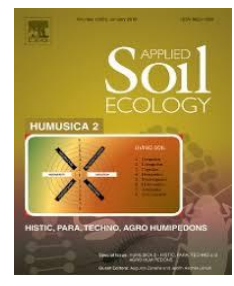

${ }^{3}$ Institute of Soil and Environmental Sciences, University of Agriculture, Faisalabad, Pakistan

${ }^{4}$ Department of Agricultural Soil Science, University of Göttingen, Göttingen, Germany

\subsubsection{Abstract}

Land-use change, especially from forest to intensive agriculture, is negatively impacting soil quality and sustainability. Soil biological activities are sensitive indicators of such land-use impacts. We tested two hypotheses: i) land use and management practices affect microbial properties (microbial biomass and enzyme activities) in topsoil $(0-20 \mathrm{~cm})$, but have no effects in subsoil $(20-100 \mathrm{~cm})$; and ii) microbial properties in topsoil are highest in forest, followed by organic farming and then conventional farming. Total organic $\mathrm{C}$ and $\mathrm{N}$ contents as well as microbial biomass were significantly higher in the organic farming topsoil compared with conventional farming and forest. Except xylanase and acid phosphatase, enzyme activities ( $\beta$-glucosidase, cellobiohydrolas, chitinase, sulfatase, leucine aminopeptidase, and tyrosine aminopeptidase) were also higher in organic farming soil. Crop residues and rhizodeposits support higher microbial biomass, leading to enhanced enzyme activities in organic farming soil. Incorporation of rice stubble and limitation of available phosphorus explain the higher xylanase and acid phosphatase activities, respectively, in conventional farming soil. Litter removal leads to a deficiency of labile $\mathrm{C}$ and $\mathrm{N}$, resulting in lower enzyme activities in forest soil. Total $\mathrm{C}$ and $\mathrm{N}$ contents were higher in subsoil under organic farming. Although there was no effect of land use on microbial biomass in subsoil, activities of most enzymes were higher under organic farming. Overall, our results indicate that land-use change significantly alters microbial properties in topsoil, with modest effects in subsoil. Microbial properties should be considered in environmental risk assessments and models as indicators of ecosystem disturbance caused by land-use and management practices.

Keywords: Land use; forest; organic farming; conventional farming; soil quality; soil depth 
Corresponding author: Menuka Maharjan, menuka48maharjan@gmail.com

\subsubsection{Introduction}

Land-use change is one of the main drivers of global environmental disturbance, greatly contributing to climate change, loss of ecosystem services and species extinctions (Turner et al., 2007; Tilman et al., 2001). The expansion of crop and pastoral land into natural ecosystems is the major form of land conversion (Lambin and Meyfroidt, 2011). Approximately $50 \%$ of the new arable land during the period of 1980-2000 came from intact forest in the tropics, while $28 \%$ came from disturbed forest. Land is becoming a scarce resource in the global context (Lambin and Meyfroidt, 2011) with the ever increasing need for agricultural land necessary to feed the growing human population.

Conversion of forest to agriculture and agricultural intensification contribute to the loss of soil organic matter (Lagomarsino et al., 2011), alter microbial biomass and its activities, and ultimately affect soil quality (Schloter et al., 2003). There is a growing global interest in the assessment of land use and management effects on physical, chemical and biological properties of soils (Nguyen et al., 1995). Microbial and biochemical characteristics of soil have been proposed as indicators of soil quality in both, natural and agricultural systems (Karlen et al., 1997; Mganga et al., 2016), due to the central role of microorganisms in C, N and nutrient cycling, and their sensitivity to alternations in soil conditions (Nannipieri et al., 2003). Extracellular enzymes, which are mainly secreted by microorganisms, play vital roles in nutrient cycling and soil organic matter (SOM) decomposition (Klose and Tabatabai, 2002). They can therefore be used as a 'soil fertility index' (Mganga et al., 2016). Land use and management practices have significant effects on microbial and enzyme activities as a result of fertilizer application (Allison et al., 2010; Zimmermann and Bird, 2012; van Gestel et al., 2013), tillage (Deng and Tabatabai, 1997; Balota et al., 2004) and grazing (Holt, 1997). Enzyme activities are also significantly affected by crop species and residue management practices (Bolton et al., 1985; Friedel et al., 1996). While prior studies have investigated the effects of land use and management practices on enzyme activities and microbial process in tropical soils, most analyses were limited to the topsoil (Balota et al., 2004; Acosta-Martínez et al., 2007; Tischer et al., 2014a; Tischer et al., 2014b; Mganga et al., 2015). Thus, although the effects of management practices on soil microbial properties are much discussed, our knowledge of their vertical distribution is scant. 
The study site in "Chitwan district" lies in the Terai region, a plain in southern Nepal. Known as grain house of Nepal, the Terai region covers $17 \%$ of the country's total land area. Forests, which cover 411,580 ha $(20.41 \%)$ of the region's total land area $(2,016,998$ ha) (FRA/DFRS, 2014),are, dominated by Shorea robusta and possess high economic value and biological diversity. After eradication of malaria in the 1950s, a resettlement and migration scheme from the Middle Mountain region to different parts of the Terai region was induced. As the population increased, massive deforestation occurred to make way for cultivation and new settlements. The region's current population growth rate is $1.75 \%$, the highest in Nepal, is continuously increasing pressure on forest areas (FRA/DFRS, 2014). Agricultural intensification through conventional farming practices is also being implemented to feed the growing population.

The objective of this study was to assess the effect of three land use systems, i.e. forest, organic and conventional farming, on soil microbial biomass and the activities of enzymes involved in the $\mathrm{C}$-cycle ( $\beta$-glucosidase, cellobiohydrolase and xylanase), $\mathrm{N}$-cycle (chitinase, leucine aminopeptidase and tyrosine aminopeptidase), P-cycle (acid phosphatase) and Scycle (sulfatase) in subtropical soil. We hypothesized that i) land use and management practices affect microbial properties (microbial biomass and enzyme activities) in topsoil, but have no effect in subsoil; and ii) microbial properties in the topsoil are higher in forest followed by organic farming and conventional farming. To test our hypotheses, we determined microbial biomass and the activities of eight enzymes involved in soil organic matter decomposition.

\subsubsection{Materials and Methods}

\subsubsection{Site and soil sampling}

The study was conducted in Chitwan district $\left(27^{\circ} 35^{\prime} \mathrm{N} 84^{\circ} 30^{\prime} \mathrm{E}\right)$ of Nepal. Three land-use systems were selected: forest, organic, and conventional farming. Both farming sites were located in Fulbari Village Development Committee (VDC) and the forest site in Patihani VDC. The climate is subtropical with annual rainfall of $1763 \mathrm{~mm}$ and an average temperature of $30{ }^{\circ} \mathrm{C}$. The soils at the study sites are Gleyic Cambisols (organic farming and forest) and Eutric Cambisol for the conventional farming site (IUSS Working Group WRB, 2015). The soil texture at all sites is sandy loam. 
The organic farm site has been under organic farming practices for 15 years. The crop rotations are maize+rice+vegetables/mustard and maize+rice+wheat/lentils for the organic and conventional farms, respectively. The organic farm was under vegetable farming during soil sampling while the conventional farm was fallow with remaining rice stubbles. The broad leaf forest is dominated by Shorea robusta commonly known as Sal. The leaves of Sal are collected by local people for performing social and religious activities. A detailed description of land uses is given in Table 1.

Table 1 Description of land use in the study site

\begin{tabular}{|c|c|c|c|}
\hline Land use & $\begin{array}{l}\text { Vegetation type/ } \\
\text { Crop rotation }\end{array}$ & $\begin{array}{c}\text { Management } \\
\text { Practices }\end{array}$ & Pesticide \\
\hline $\begin{array}{l}\text { Organic farming }= \\
15 \text { years }\end{array}$ & $\begin{array}{l}\text { Maize+ rice+ vegetables } \\
\text { / mustard }\end{array}$ & $\begin{array}{l}\text { Farmyard manure:10 ton } \\
\text { ha }^{-1} \mathrm{yr}^{-1} \text { and } \\
\text { Vermicomposting }\end{array}$ & No \\
\hline $\begin{array}{l}\text { Conventional } \\
\text { farming }\end{array}$ & Maize+ rice+ wheat/ lentil & $\begin{array}{l}\text { Urea: } 60 \mathrm{~kg} \mathrm{ha}{ }^{-1} \mathrm{yr}^{-1} \\
\text { Potassium: } 15 \mathrm{~kg} \mathrm{ha}^{-1} \mathrm{yr}^{-1}\end{array}$ & Yes \\
\hline Forest & $\begin{array}{l}\text { Broad leaf dominated } \\
\text { by Shroea robusta }\end{array}$ & $\begin{array}{l}\text { Collection of litter for social } \\
\text { and religious activities }\end{array}$ & No \\
\hline
\end{tabular}

\subsubsection{Soil sampling and preparation}

Soils from the three land use systems were sampled from $0-100 \mathrm{~cm}$ depth at intervals of 10 $\mathrm{cm}$. The samples were kept cold $\left(\sim 4{ }^{\circ} \mathrm{C}\right)$ during transportation to the laboratory. Plant remains, debris, and roots were removed using tweezers. The field-moist soil $(70 \%$ of $\mathrm{WHC}$ ) was allowed to equilibrate at room temperature for $24 \mathrm{~h}$ prior to analysis.

\subsubsection{Microbial biomass carbon and nitrogen}

Microbial biomass $\mathrm{C}$ and $\mathrm{N}$ was determined by the chloroform fumigation-extraction method (Vance et al., 1987), based on the difference between $C$ or $N$ extracted from fumigated and non-fumigated soil samples using $0.05 \mathrm{M} \mathrm{K}_{2} \mathrm{SO}_{4}$. A $\mathrm{k}_{\mathrm{EC}}$ factor 0.45 was used to convert microbial $C$ flush into microbial biomass $C$ (Joergensen, 1996), while a $k_{E N}$ of 0.54 was used for microbial biomass N (Joergensen and Mueller, 1996).

\subsubsection{Enzyme assays}

Enzyme kinetics were assayed using fluorogenically labeled substrates based on 4methylumbelliferone (MUF) and amino-4-methyl coumarin (AMC)-, (Pritsch et al., 2004), 
(Table S1). The MUF and AMC substrates were dissolved in 2-methoxyethanol (Hoppe, 1983) and the dissolved substrates were further diluted with sterile water. Enzymesaturating concentrations of fluorogenic substrates were determined in a preliminary experiment (Razavi et al., 2015). All chemicals and substrates were purchased from Sigma, Germany.

Briefly, soil $(1 \mathrm{~g})$ from each of the three land uses and different soil depths $(0-100 \mathrm{~cm}$ depth at intervals of $10 \mathrm{~cm}$ ) was suspended with $50 \mathrm{ml}$ of sterile water using low-energy sonication (40 $\mathrm{J} \mathrm{s}^{-1}$ output energy for $2 \mathrm{~min}$ ). Following sonication, $50 \mu \mathrm{l}$ of soil suspension was added to $100 \mu \mathrm{l}$ of substrate solution and $50 \mu \mathrm{l}$ of buffer (either MES, TRIZMA or sodium acetate, see Table S1) in a 96-well microplate and incubated for $2 \mathrm{~h}$ (Koch et al., 2007). Fluorescence was measured at an excitation wavelength of $355 \mathrm{~nm}$ and an emission wavelength of $460 \mathrm{~nm}$, split width of $25 \mathrm{~nm}$, with a Victor ${ }^{3} 1420-050$ Multilabel Counter (PerkinElmer, USA). Calibration curves as well as controls for autofluorescence of the substrate were included in each series of enzyme measurements. Enzymes activities were expressed as MUF or AMC released in nmol per $\mathrm{g}$ dry soil per hour ( $\mathrm{nmol} \mathrm{g}{ }^{-1}$ soil h$^{-1}$ ), (Razavi et al., 2015).

\subsubsection{Elemental analysis}

Oven dried subsamples of soil $\left(60^{\circ} \mathrm{C}\right)$ were ground and analyzed for elemental $\mathrm{C}$ and $\mathrm{N}$ with an Elementar Vario El analyzer (Elementar Analysensysteme GmbH, Germany).

\subsubsection{Calculations and statistical analysis}

The effects of land use on microbial properties were analyzed using one-way analysis of variance (ANOVA) at a significance level of $p<0.05$ using the statistical software Statistica 12. All displayed results represent means of 3 replicates \pm standard error (SE).

\subsubsection{Results}

\subsubsection{Soil and microbial carbon and nitrogen}

Land use had significant effects on total organic $\mathrm{C}$ and $\mathrm{N}$ contents in topsoil (Fig. 1). Total soil organic $\mathrm{C}$ was highest in organic farming (24 mg C g-1 soil) followed by conventional farming (15 mg C g-1 soil) and forest ( $9 \mathrm{mg} \mathrm{C} \mathrm{g-1} \mathrm{soil)} \mathrm{in} \mathrm{the} \mathrm{topsoil} \mathrm{layer} \mathrm{(0-10} \mathrm{cm} \mathrm{depth).}$ Total $\mathrm{C}$ content declined with increasing soil depth, remaining highest in the organic farming soil al all depths tested. A similar trend was found for total $\mathrm{N}$ content in all three 
land uses (Fig. 1), with organic farming soil possessing the highest total $\mathrm{N}$ content in both top and subsoil.

Similarly, microbial $\mathrm{C}$ and $\mathrm{N}$ were also highest under organic farming, especially in the topsoil layer (350 and $46 \mu \mathrm{g} \mathrm{g-1}$ soil, respectively), (Fig. 1). However, conventional farming and forest soils had similar microbial biomass content. In subsoil, there were no significant effects of land-use changes on microbial biomass $\mathrm{C}$ and $\mathrm{N}$. Positive correlations were found for total soil $C$ and $N$ with microbial biomass $C$ and $N\left(R^{2}>0.71\right.$ and $R^{2}=0.32-0.77$, $\mathrm{P}<0.05$, respectively).

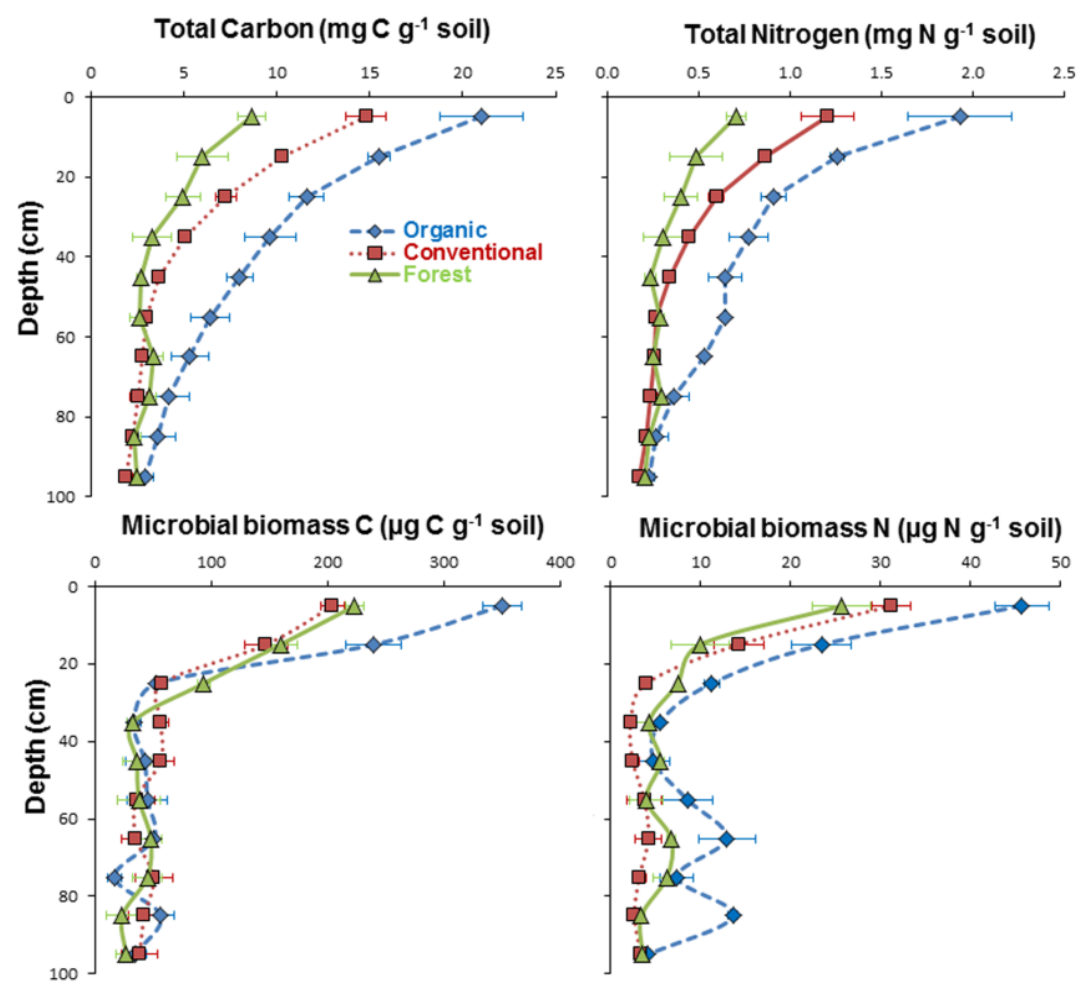

Figure 1 Total $C, N$, and microbial biomass $C$ and $N$ depending on land use and depth. Values represent means \pm SE $(n=3)$.

\subsubsection{Enzyme activities}

\subsection{Carbon-cycle enzyme activities}

The activities of enzymes involved in the C-cycle ( $\beta$-glucosidase, cellobiohydrolase, and xylanase) were significantly affected by land use, especially in topsoil (Fig. 2). The activity of $\beta$-glucosidase was higher in organic farming (199 $\mathrm{nmol} \mathrm{g}^{-1}$ soil $\mathrm{h}^{-1}$ ) followed by conventional farming $\left(130 \mathrm{nmol} \mathrm{g}^{-1}\right.$ soil h$\left.^{-1}\right)$ and forest soil $\left(19 \mathrm{nmol} \mathrm{g}^{-1}\right.$ soil h$\left.^{-1}\right)$ in the topsoil layer. The activity of cellobiohydrolase was higher in organic farming compared to forest 
soil, but was similar in organic and conventional farming soil. In contrast, xylanase activity was higher under conventional farming $\left(27 \mathrm{nmol} \mathrm{g}^{-1}\right.$ soil $\left.^{-1}\right)$ followed by organic farming (17 $\mathrm{nmol} \mathrm{g}{ }^{-1}$ soil h$^{-1}$ ) and forest soil (12 $\mathrm{nmol} \mathrm{g}^{-1}$ soil h$^{-1}$ ), (Fig. 2). Carbon-cycle-related activities were higher in organic farming subsoil, but were similar for the conventional farming and forest soils.

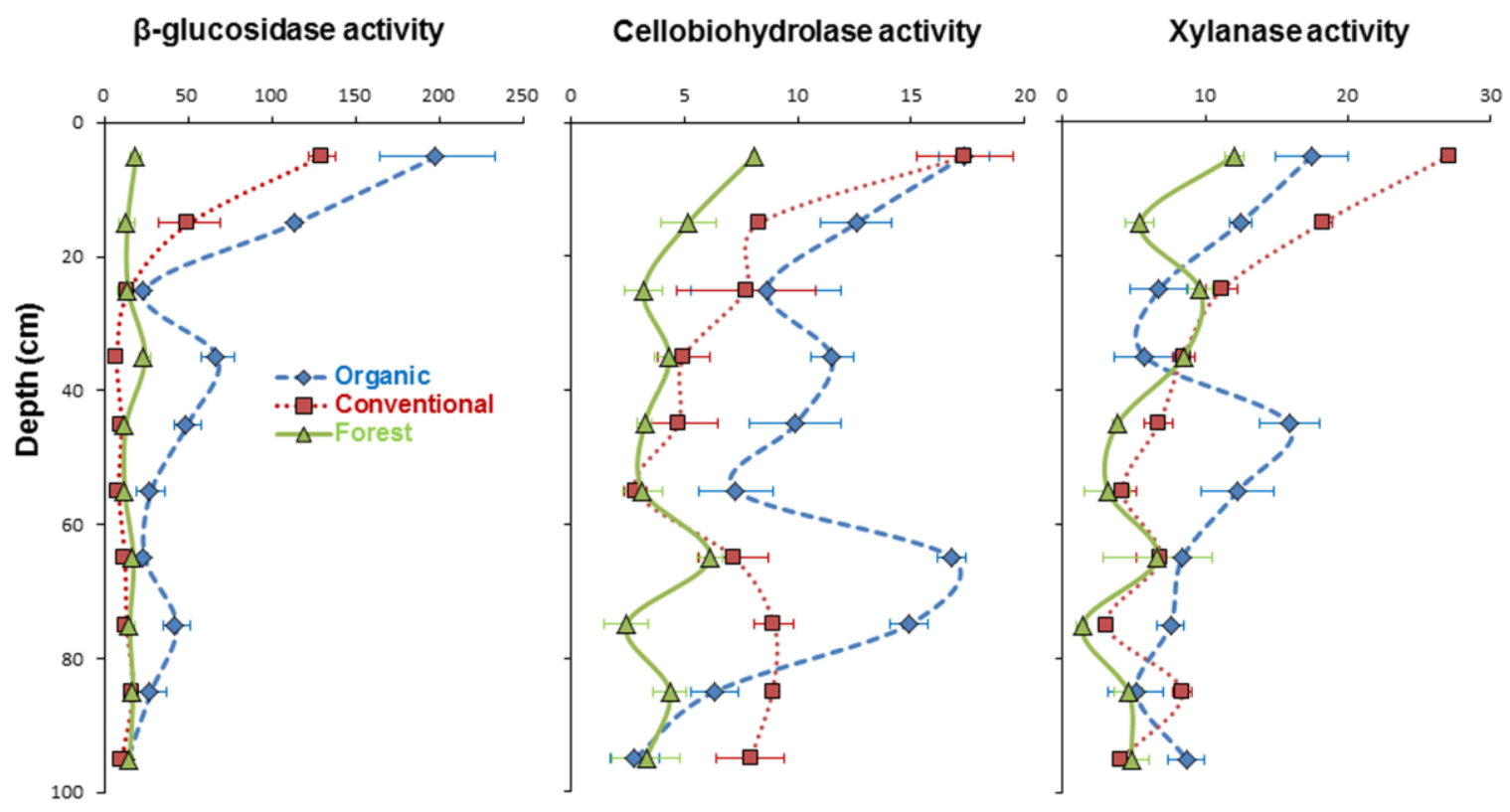

Figure 2 Activities of C-cycle enzymes: $\beta$-glucosidase, cellobiohydrolase, and xylanase depending on land use and depth. Values represent means \pm SE $(n=3)$. Enzyme activities are expressed in nmol g ${ }^{-1}$ soil $h^{-1}$.

\subsection{Nitrogen-cycle enzyme activities}

The activities of $\mathrm{N}$-cycle enzymes (chitinase, leucine aminopeptidase and tyrosine aminopeptidase) in the topsoil layer were higher under organic farming (138, 276 and 255 $\mathrm{nmol} \mathrm{g}^{-1}$ soil $^{-1}$, respectively) compared with other land-use systems (Fig. 3). The activities of tyrosine aminopeptidase and chitinase were also higher in subsoil under organic farming (Fig. 3). 


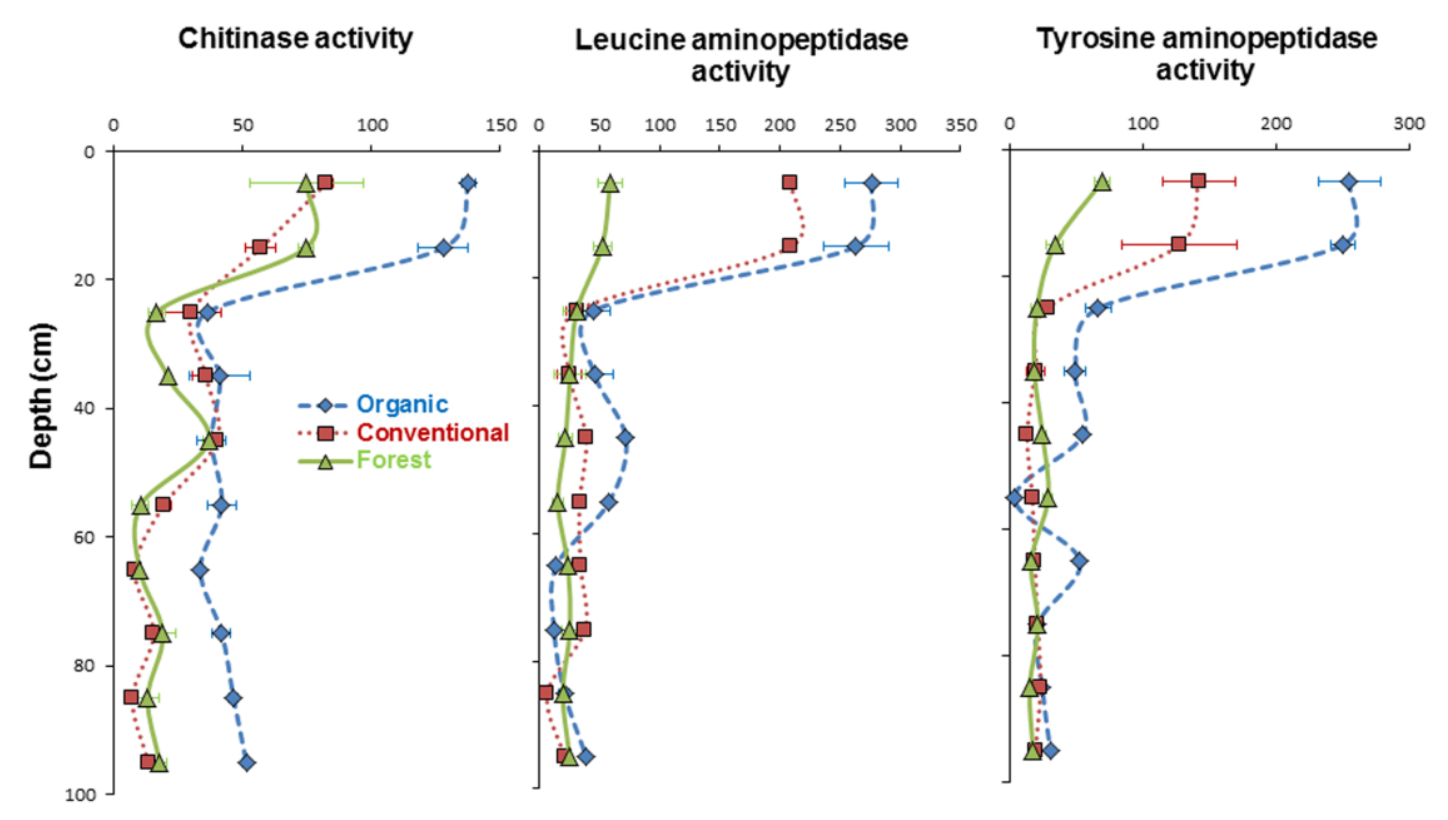

Figure 3 Activities of $\mathrm{N}$-cycle enzymes: chitinase, leucine aminopeptidase, and tyrosine aminopeptidase depending on land use and depth. Values represent means $\pm S E(n=3)$. Enzyme activities are expressed in $\mathrm{nmol} \mathrm{g}^{-1}$ soil $\mathrm{h}^{-1}$.

\subsection{Phosphorus- and sulfur-cycle enzyme activities}

Acid phosphatase (P-cycle) activity in topsoil was affected by land use (Fig. 4). In contrast to $\mathrm{C}$ - (except xylanase) and $\mathrm{N}$-cycle enzymes, the activity of acid phosphatase in the topsoil layer was higher under conventional farming $\left(936 \mathrm{nmol} \mathrm{g}^{-1}\right.$ soil $\left.\mathrm{h}^{-1}\right)$ followed by forest $\left(672 \mathrm{nmol} \mathrm{g}^{-1}\right.$ soil $\left.^{-1}\right)$ and organic farming soil $\left(118 \mathrm{nmol} \mathrm{g}^{-1}\right.$ soil $\left.^{-1}\right)$. Under organic farming, acid phosphatase activity increased with increasing depth, while the opposite trend was noted for conventional farming and forest soil. The activity of the S-cycle enzyme, sulfatase, in the topsoil was higher in organic farming $\left(39 \mathrm{nmol} \mathrm{g}^{-1} \mathrm{soil} \mathrm{h}^{-1}\right)$ followed by conventional farming $\left(14 \mathrm{nmol} \mathrm{g}^{-1}\right.$ soil h$\left.^{-1}\right)$ and forest $\left(5 \mathrm{nmol} \mathrm{g}{ }^{-1}\right.$ soil $\left.\mathrm{h}^{-1}\right)$ (Fig. 4$)$, with similar trends identified in the subsoil.

Among C-cycle enzymes, $\beta$-glucosidase (except for forest), cellobiohydrolase and xylanase activities were positively correlated with microbial biomass C (Fig. S1). The activity of acid phosphatase showed a positive correlation with microbial biomass $C$ in conventional farming and forest but a negative correlation in organic farming (Fig. S1). The activities of $\mathrm{N}$-cycle enzymes were positively correlated with microbial biomass $\mathrm{N}$ (Fig. S2). There was positive correlation between sulfatase activity and microbial biomass $\mathrm{C}$ in both agricultural soils (Fig. S2). 


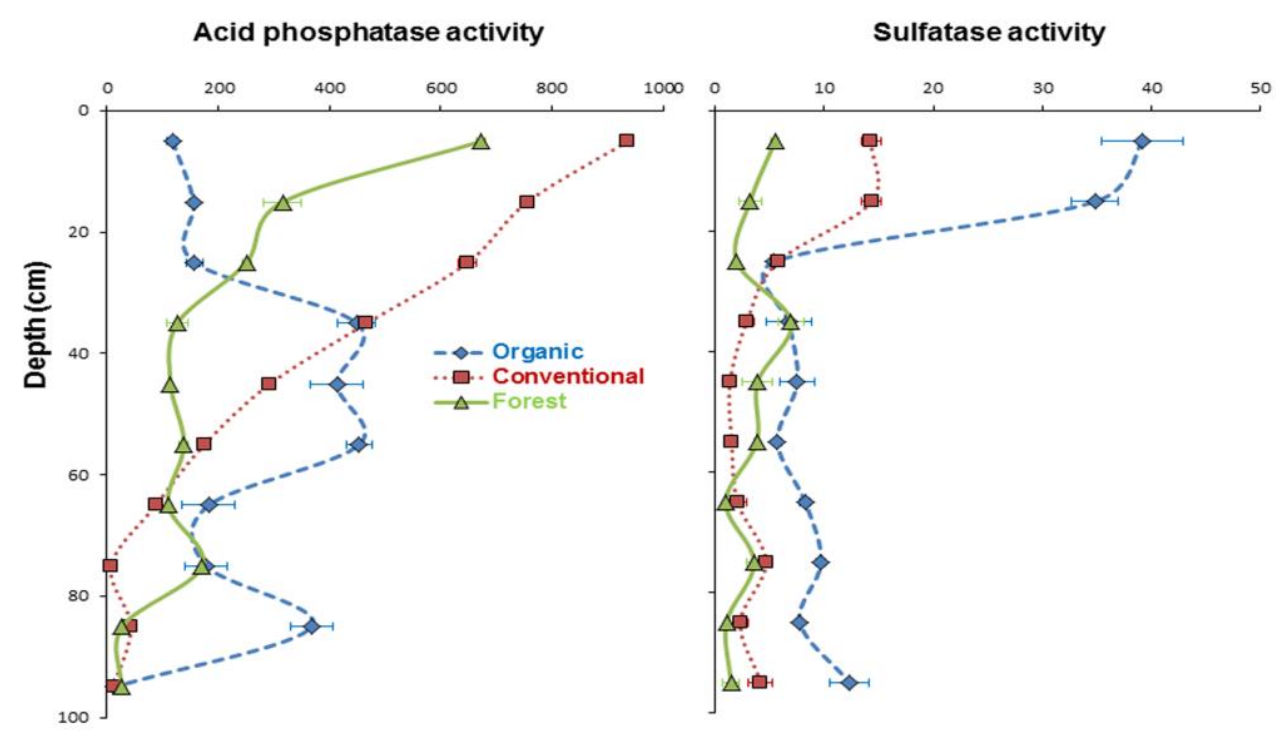

Figure 4 Activities of $P$ and S-cycle enzymes: acid phosphatase and sulfatase depending on land use and depth. Values represent means \pm SE $(n=3)$. Enzyme activities are expressed in $n m o l ~ g^{-1}$ soil $h^{-1}$.

\subsubsection{Discussion}

\subsubsection{Soil and microbial carbon and nitrogen}

Soil and microbial $\mathrm{C}$ and $\mathrm{N}$ decrease with depth due to declining $\mathrm{C}$ input (e.g. by plant residues) (Hu et al., 1997). However, soil $\mathrm{C}$ and $\mathrm{N}$ contents remained higher in subsoil under organic farming compared to other land uses, possibly due to effect of vermicompost application in organic management (Azarmi et al., 2008). In contrast to total $\mathrm{C}$ and $\mathrm{N}$ content, microbial biomass ( $\mathrm{C}$ and $\mathrm{N}$ ) in subsoil was similar among the different land use systems. This indicates that land use and management practices affected microbial biomass only in the topsoil (Liang et al., 2012), confirming our first hypothesis.

Microbial biomass $\mathrm{C}$ and $\mathrm{N}$ in topsoil followed the order: organic farming > conventional farming $=$ forest soil which contradicts hypothesis (ii), (Fig. 1). Higher soil $\mathrm{C}$ and $\mathrm{N}$ in organic farming is mainly due to the regular application of farmyard manure and vermicomposting (Table 1 and Fig. 5). Farmyard manure supplies readily available N, resulting higher plant biomass. As a result, more crop residues are incorporated through tillage, which maintains higher OM ( $\mathrm{C}$ and N) levels in surface layers (Roldán et al., 2005). This also provides a favorable environment for microorganisms, contributing to a highly diverse and stable microbial community structure in organic farming systems (Wada and Toyota, 2007). In conventional farming, fallow periods in the crop rotation interrupt the continuous incorporation of crop residues, resulting in lower OM than for organic farming 
(Fig. 1, 5). In addition, toxic effects of pesticides may reduce the microbial biomass in conventional farming (Table 1). In the forest system, regeneration and crown density is very low. Furthermore, litter is collected by villagers for performing social and religious activities (Table 1), leading to decreased $\mathrm{C}$ and $\mathrm{N}$ content relative to organic or conventional farming systems (Fig. 5). Consequently, microbial biomass was lower in forest than in the organic farming system.

The correlation of microbial biomass $\mathrm{C}$ and $\mathrm{N}$ with total organic $\mathrm{C}$ and $\mathrm{N}$, reflects that microbial biomass is determined by the quantity and quality of OM (Kallenbach and Grandy, 2011). Thus, an increase or decrease in soil and microbial $C$ and $N$ content is particularly dependent on management practices.

\subsubsection{Enzyme activities}

In topsoil, enzyme activities other than xylanase and acid phosphatase followed the order: organic farming $\geq$ conventional farming $\geq$ forest soil (Fig. 2, 3,4), which is contrary to hypothesis (ii). Higher plant growth, due to farmyard manure input, supports high microbial biomass in the organic farming system. In addition, continuous plant cover as well as varied plant species provide different qualities and quantities of crop residue and root exudates, which are substrates for microorganisms and thereby support enzyme production (Nayak et al., 2007). The continuous application of farmyard manure enhances the substrate utilization capacity of microorganisms (Wada and Toyota, 2007). Consequently, microorganisms are activated, contributing to higher enzyme activities and accelerated SOM decomposition (Fig. 5). Elevated chitinase and sulfatase activities imply that fungal biomass is high in the organic farming system (Bandick and Dick, 1999; Badiane et al., 2001), indicating a difference in microbial community resulting from the input of organic matter (Marschner et al., 2003). However, activities of xylanase and acid phosphatase were higher in the conventional farming system (Fig. 2, 4). Incorporation of rice stubble explains the higher activity of xylanase. Hemicellulose is an insoluble substance contained in plant root detritus (Kandeler et al., 1999). The higher availability of these organic compounds stimulates the production of xylanase by the microbial community (Allison and Vitousek, 2005), demonstrating that enzyme activities are significantly affected by cropping and residue management practices (Kandeler et al., 1999; Allison and Vitousek, 2005). The higher activity of acid phosphatase is mainly due to production of this common enzyme by both plants and microorganisms (Blagodatskaya and Kuzyakov, 2008; Nannipieri et al., 2012) and also probably high demand for P (Allison and 
Vitousek, 2005; Frank and Groffman, 2009; Razavi et al., 2016). A weak or non-significant correlation between microbial biomass and enzyme activities (except acid phosphatase) in forest soil indicates that microorganisms are dormant due to the limited availability of labile $\mathrm{C}$ and $\mathrm{N}$ in this ecosystem (Fig. S1, S2, 5). Consequently, enzyme activities are low in the forest system (Fig. 2, 3, 4).

Concerning the subsoil, the general trend of enzyme activities demonstrated a gradual decrease with depth (except for acid phosphatase and xylanase, in organic farming). Reduced enzyme activities along with microbial biomass in subsoil is connected to decreasing $C$ input and content (Agnelli et al., 2004; Goberna et al., 2006). According to our hypothesis (i), we expected no effect of land use on subsoil. This hypothesis is partly supported by C-, N-, P- and S-cycle enzymes in all land-use systems, with the exception of seven enzymes in organic farming (Fig. 2, 3, 4). The activity of acid phosphatase was increased in subsoil in organic farming relative to other land uses. High activity of phosphatase in top- and sub-soil indicated a high investment of microorganisms and plants for the acquisition of $P$ (Fig. 4). By this belowground $C$ investment, plants regulate increase the availability of organically bound $P$ from sub-soil in the tropics. Higher activities of enzymes involved in cellulose and hemicellulose decomposition in the organic farming system are due to the favorable environment for C-degrading microorganisms in the subsoil. The higher water content following rice cultivation could also be a contributing factor. Additionally, the higher activities of enzymes are indicate for the presence of complex substrates (German et al., 2011). This explains the similar behavior of enzymes degrading C-polymers, N-polymers (chitinase and tyrosine aminopeptidase) and Scontaining molecules in the organic farming system. In general, application of vermicomposts simulate activities of some enzymes (Atiyeh et al., 2001; Benitez et al., 2004) in organic farming. Positive correlations between enzyme activities and microbial biomass in conventional and organic farming systems (except for acid phosphatase) (Fig. $\mathrm{S} 1, \mathrm{~S} 2$ ) reflect the microbial origin of the enzymes (Nayak et al., 2007; Wallenius et al., 2011). 


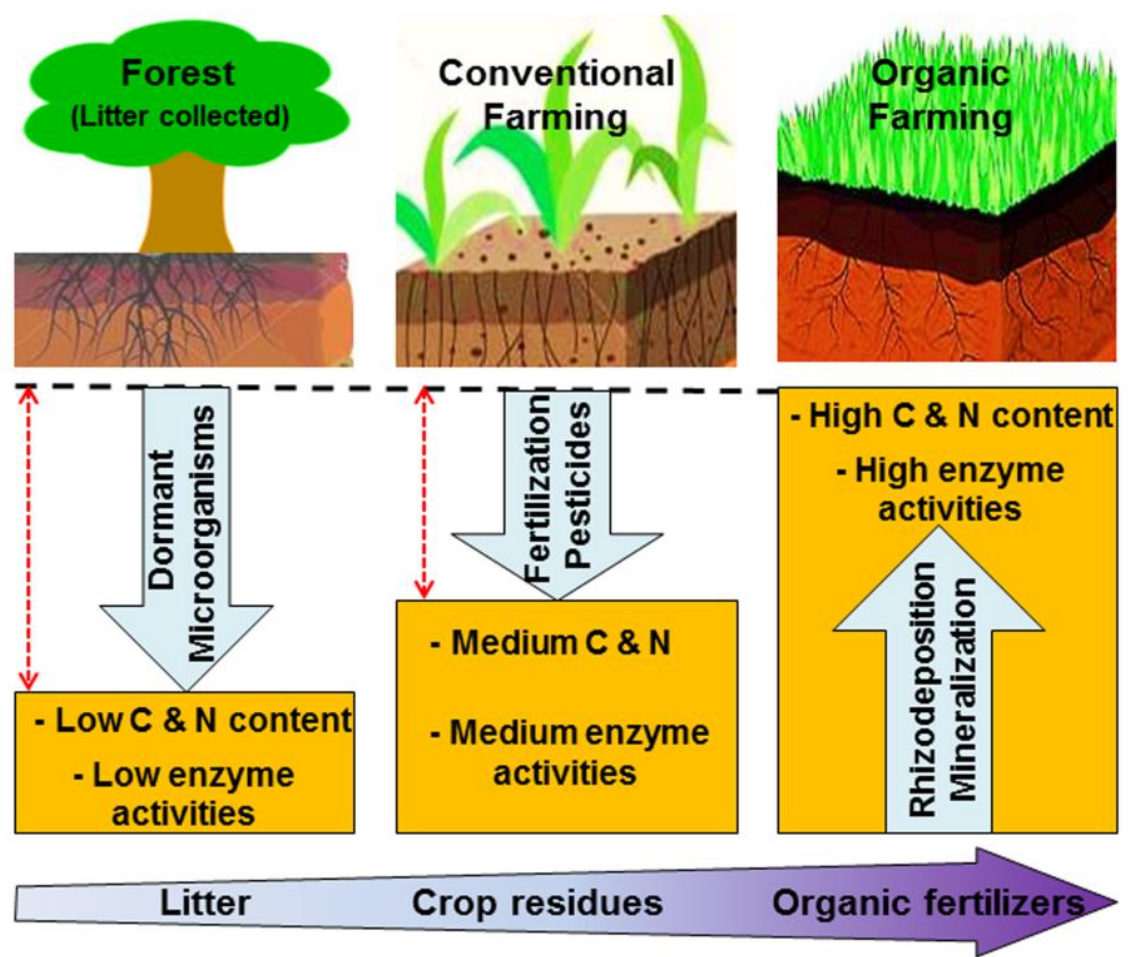

Figure 5 The effect of land use on carbon and nitrogen content in soil along with enzyme activities.

\subsubsection{Conclusions}

Total organic $\mathrm{C}$ and $\mathrm{N}$, soil microbial biomass and enzyme activities other than xylanase and acid phosphatase were higher in organic farming than in conventional farming and forest topsoil. Organic matter input under various management practices is the most important factor for determining $\mathrm{C}$ and $\mathrm{N}$ content and microbial properties. In the subsoil, microbial biomass was similar among land-use systems, although enzyme activities were slightly higher under organic farming. These results demonstrate that land use and management practices have significant effects on microbial properties in surface layers, with lesser effects in subsoil. Microbial response to resource limitation and substrate availability determines the production of enzymes in different land use systems. Thus, microbial properties can serve as potential biological indicators of ecological changes resulting from land-use and management practices in subtropical top-and sub-soils.

\subsubsection{Acknowledgement}

We acknowledge the Erasmus mundus (Experst4Asia) for financial support of Menuka Maharjan and Alexander von Humboldt Foundation for financial support of Muhammad 
Sanaullah. The authors would like to thank Karin Schmidt and Anita Kriegel, for laboratory assistance. We would also like to acknowledge two anonymous reviewers for their constructive comments on the manuscript.

\subsubsection{Reference}

Acosta-Martínez, V., Cruz, L., Sotomayor-Ramírez, D., Pérez-Alegría, L., 2007. Enzyme activities as affected by soil properties and land use in a tropical watershed. Appl. Soil Ecol. 35, 35-45. doi:10.1016/j.apsoil.2006.05.012

Agnelli, A., Ascher, J., Corti, G., Ceccherini, M.T., Nannipieri, P., Pietramellara, G., 2004. Distribution of microbial communities in a forest soil profile investigated by microbial biomass, soil respiration, and DGGE of total and extracellular DNA. Soil Biol. Biochem. 36, 859-868. doi:10.1016/j.soilbio.2004.02.004

Allison, S.D., Vitousek, P.M., 2005. Responses of extracellular enzymes to simple and complex nutrient inputs. Soil Biol. Biochem. 37, 937-944. doi:10.1016/j.soilbio.2004.09.014

Allison, S.D., Wallenstein, M.D., Bradford, M.A., 2010. Soil-carbon response to warming dependent on microbial physiology. Nat. Geosci. 3, 336-340. doi:10.1038/ngeo846

Atiyeh, R.M., Edwards, C.A., Subler, S., Metzger, J.D., 2001. Pig manure vermicompost as a component of a horticultural bedding plant medium: Effects on physicochemical properties and plant growth. Bioresour. Technol. 78, 11-20. doi:10.1016/S0960-8524(00)00172-3

Azarmi, R., Giglou, M., Taleshmikail, R., 2008. Influence of vermicompost on soil chemical and physical properties in tomato (Lycopersicum esculentum) field. African J. Biotechnol. 7, 2397-2401. doi:10.4314/ajb.v7i14.59004

Badiane, N.N.Y., Chotte, J.., Pate, E., Masse, D., Rouland, C., 2001. Use of soil enzyme activities to monitor soil quality in natural and improved fallows in semi-arid tropical regions. Appl. Soil Ecol. 18, 229-238. doi:10.1016/S0929-1393(01)00159-7

Balota, E.L., Kanashiro, M., Colozzi Filho, A., Andrade, D.S., Dick, R.P., 2004. Soil enzyme activities under long-term tillage and crop rotation systems in subtropical agro-ecosystems. Brazilian J. Microbiol. 35, 300-306. doi:10.1590/S1517-83822004000300006

Bandick, A.K., Dick, R.P., 1999. Field management effects on soil enzyme activities. Soil Biol. Biochem. 31, 1471-1479. doi:10.1016/S0038-0717(99)00051-6

Benitez, E., Melgar, R., Nogales, R., 2004. Estimating soil resilience to a toxic organic waste by measuring enzyme activities. Soil Biol. Biochem. 36, 1615-1623. doi:10.1016/j.soilbio.2004.07.014

Blagodatskaya, E., Kuzyakov, Y., 2008. Mechanisms of real and apparent priming effects and their dependence on soil microbial biomass and community structure: critical review. Biol. Fertil. Soils 45, 115-131. doi:10.1007/s00374-008-0334-y

Bolton, H., Elliott, L.F., Papendick, R.I., Bezdicek, D.F., 1985. Soil microbial biomass and selected soil enzyme activities: Effect of fertilization and cropping practices. Soil Biol. Biochem. 17, 297-302. doi:10.1016/0038-0717(85)90064-1

Deng, S.P., Tabatabai, M.A., 1997. Effect of tillage and residue management on enzyme activities in soils. Biol. Fertil. Soils 22, 202-207. doi:10.1007/BF00382513

FRA/DFRS, 2014. Terai Forests of Nepal (2010-2012). Babarmahal, Kathmandu:Forest Resources Assessment Nepal Project/Department of Forest Research and Survey.

Frank, D., Groffman, P.., 2009. Plant rhizospheric N processes: what we don't know and why we should care. Ecol. I N 90, 1512-1519.

Friedel, J.K., Munch, J.C., Fischer, W.R., 1996. Soil microbial properties and the assessment of available soil organic matter in a haplic Luvisol after several years of different cultivation and crop rotation. Soil Biol. Biochem. 28, 479-488. doi:10.1016/0038-0717(95)00188-3

Goberna, M., Sánchez, J., Pascual, J.A., García, C., 2006. Surface and subsurface organic carbon, microbial biomass and activity in a forest soil sequence. Soil Biol. Biochem. 38, 2233-2243. doi:10.1016/j.soilbio.2006.02.003

Holt, J. a., 1997. Grazing pressure and soil carbon, microbial biomass and enzyme activities in semiarid northeastern Australia. Appl. Soil Ecol. 5, 143-149. doi:10.1016/S0929-1393(96)00145$\mathrm{X}$ 
Hoppe, H.G., 1983. Significance of exoenzymatic activities in the ecology of Brackish Water: measurements by means of Methylumbelliferyl-substrates. Mar. Ecol. Prog. Ser. 11, 299308.

Hu, S., Coleman, D.C., Carroll, C.R., Hendrix, P.F., Beare, M.H., 1997. Labile soil carbon pools in subtropical forest and agricultural ecosystems as influenced by management practices and vegetation types. Agric. Ecosyst. Environ. 65, 69-78. doi:10.1016/S0167-8809(97)00049-2

IUSS Working Group WRB, 2015. World Reference Base for Soil Resources for 2014. World Soil Resources Report No. 106. FAO, Rome, 203 pp.

Joergensen, R.G., 1996. The fumigation-extraction method to estimate soil microbial biomass: Calibration of the kEC value. Soil Biol. Biochem. 28, 25-31. doi:10.1016/00380717(95)00102-6

Joergensen, R.G., Mueller, T., 1996. The fumigation-extraction method to estimate soil microbial biomass: Calibration of the kEN value. Soil Biol. Biochem. 28, 33-37. doi:10.1016/00380717(95)00101-8

Kallenbach, C., Grandy, A.S., 2011. Controls over soil microbial biomass responses to carbon amendments in agricultural systems: A meta-analysis. Agric. Ecosyst. Environ. 144, $241-$ 252. doi:10.1016/j.agee.2011.08.020

Kandeler, E., Stemmer, M., Klimanek, E.-M., 1999. Response of soil microbial biomass, urease and xylanase within particle size fractions to long-term soil management. Soil Biol. Biochem. 31, 261-273. doi:10.1016/S0038-0717(98)00115-1

Kandeler, E., Tscherko, D., Spiegel, H., 1999. Long-term monitoring of microbial biomass, N mineralization and enzyme activities of a Chernozem under different tillage management. Biol. Fertil. Soils 28, 343-351. doi:10.1007/s003740050502

Karlen, D.L., Mausbach, M.J., Doran, J.W., Cline, R.G., Harris, R.F., Schuman, G.E., 1997. Soil quality: a concept, definition, and framework for evaluation. Soil Sci. Soc. Am 61, 4-10.

Klose, S., Tabatabai, M.A., 2002. Response of phosphomonoesterases in soils to chloroform fumigation. J. Plant Nutr. Soil Sci. 165, 429-434. doi:10.1002/15222624(200208) 165:4<429::AID-JPLN429>3.0.CO;2-S

Koch, O., Tscherko, D., Kandeler, E., 2007. Temperature sensitivity of microbial respiration, nitrogen mineralization, and potential soil enzyme activities in organic alpine soils. Global Biogeochem. Cycles 21, 1-11. doi:10.1029/2007GB002983

Lagomarsino, A., Benedetti, A., Marinari, S., Pompili, L., Moscatelli, M.C., Roggero, P.P., Lai, R., Ledda, L., Grego, S., 2011. Soil organic C variability and microbial functions in a Mediterranean agro-forest ecosystem. Biol. Fertil. Soils 47, 283-291. doi:10.1007/s00374010-0530-4

Lambin, E.F., Meyfroidt, P., 2011. Global land use change, economic globalization, and the looming land scarcity. Proc. Natl. Acad. Sci. U. S. A. 108, 3465-72. doi:10.1073/pnas.1100480108

Liang, Q., Chen, H., Gong, Y., Fan, M., Yang, H., Lal, R., Kuzyakov, Y., 2012. Effects of 15 years of manure and inorganic fertilizers on soil organic carbon fractions in a wheat-maize system in the North China Plain. Nutr. Cycl. Agroecosystems 92, 21-33. doi:10.1007/s10705-0119469-6

Marschner, P., Kandeler, E., Marschner, B., 2003. Structure and function of the soil microbial community in a long-term fertilizer experiment. Soil Biol. Biochem. 35, 453-461. doi:10.1016/S0038-0717(02)00297-3

Mganga, K.Z., Razavi, B.S., Kuzyakov, Y., 2016. Land use affects soil biochemical properties in Mt. Kilimanjaro region. Catena 141, 22-29. doi:10.1016/j.catena.2016.02.013

Mganga, K.Z., Razavi, B.S., Kuzyakov, Y., 2015. Microbial and enzymes response to nutrient additions in soils of Mt. Kilimanjaro region depending on land use. Eur. J. Soil Biol. 69, 3340. doi:10.1016/j.ejsobi.2015.05.001

Murphy, D.V., Sparling, G.P., Fillery, I.R.P., 1998. Stratification of microbial biomass $C$ and $N$ and gross $\mathrm{N}$ mineralisation with soil depth in two contrasting Western Australian agricultural soils. Aust J Soil Res 36, 45-55.

Nannipieri, P., Ascher, J., Ceccherini, M.T., Landi, L., Pietramellara, G., Renella, G., 2003. Microbial diversity and soil functions. Eur. J. Soil Sci. 54, 655-670. doi:10.1046/j.13510754.2003.0556.x

Nannipieri, P., Giagnoni, L., Renella, G., Puglisi, E., Ceccanti, B., Masciandaro, G., Fornasier, F., Moscatelli, M.C., Marinari, S., 2012. Soil enzymology: Classical and molecular approaches. Biol. Fertil. Soils 48, 743-762. doi:10.1007/s00374-012-0723-0 
Nayak, D.R., Babu, Y.J., Adhya, T.K., 2007. Long-term application of compost influences microbial biomass and enzyme activities in a tropical Aeric Endoaquept planted to rice under flooded condition. Soil Biol. Biochem. 39, 1897-1906. doi:10.1016/j.soilbio.2007.02.003

Nguyen, M.L., Haynes, R.J., Goh, K.M., 1995. Nutrient budgets and status in three pairs of conventional and alternative mixed cropping farms in Canterbury, New Zealand. Agric. Ecosyst. Environ. 52, 149-162. doi:10.1016/0167-8809(94)00544-O

Pritsch, K., Raidl, S., Marksteiner, E., Blaschke, H., Agerer, R., Schloter, M., Hartmann, A., 2004. A rapid and highly sensitive method for measuring enzyme activities in single mycorrhizal tips using 4-methylumbelliferone-labelled fluorogenic substrates in a microplate system. J. Microbiol. Methods 58, 233-41. doi:10.1016/j.mimet.2004.04.001

Razavi, B.S., Blagodatskaya, E., Kuzyakov, Y., 2015. Nonlinear temperature sensitivity of enzyme kinetics explains canceling effect-A case study on loamy haplic Luvisol. Front. Microbiol. 6 , 1-13. doi:10.3389/fmicb.2015.01126

Razavi, B.S., Zarebanadkouki, M., Blagodatskaya, E., Kuzyakov, Y., 2016. Rhizosphere shape of lentil and maize: Spatial distribution of enzyme activities. Soil Biol. Biochem. 96, 229-237. doi:10.1016/j.soilbio.2016.02.020

Roldán, A., Salinas-García, J.R., Alguacil, M.M., Díaz, E., Caravaca, F., 2005. Soil enzyme activities suggest advantages of conservation tillage practices in sorghum cultivation under subtropical conditions. Geoderma 129, 178-185. doi:10.1016/j.geoderma.2004.12.042

Schloter, M., Dilly, O., Munch, J.C., 2003. Indicators for evaluating soil quality. Agric. Ecosyst. Environ. 98, 255-262. doi:10.1016/S0167-8809(03)00085-9

Sinsabaugh, R.., Moorhead, D.., 1994. The enzymic basis of plant litter decomposition: emergence of an ecological process. Appl. Soil Ecol. 1, 97-111. doi:10.1016/0929-1393(94)90030-2

Tilman, D., Fargione, J., Wolff, B., D'Antonio, C., Dobson, A., Howarth, R., Schindler, D., Schlesinger, W.H., Simberloff, D., Swackhamer, D., 2001. Forecasting agriculturally driven global environmental change. Science 292, 281-4. doi:10.1126/science.1057544

Tischer, A., Blagodatskaya, E., Hamer, U., 2014a. Extracellular enzyme activities in a tropical mountain rainforest region of southern Ecuador affected by low soil $P$ status and land-use change $74,1-11$.

Tischer, A., Potthast, K., Hamer, U., 2014b. Land use and soil depth affect resource and microbial stoichiometry in a tropical mountain rainforest region of southern Ecuador 375-393. doi:10.1007/s00442-014-2894-x

Turner, B.L., Lambin, E.F., Reenberg, A., 2007. The emergence of land change science for global environmental change and sustainability. Proc. Natl. Acad. Sci. U. S. A. 104, 20666-71. doi:10.1073/pnas.0704119104

van Gestel, N.C., Reischke, S., Bååth, E., 2013. Temperature sensitivity of bacterial growth in a hot desert soil with large temperature fluctuations. Soil Biol. Biochem. 65, 180-185. doi:10.1016/j.soilbio.2013.05.016

Vance, E.D., Brookes, P.C., Jenkinson, D.S., 1987. An extraction method for measuring soil microbial biomass C. Soil Biol. Biochem. 19, 703-707. doi:10.1016/0038-0717(87)90052-6

Wada, S., Toyota, K., 2007. Repeated applications of farmyard manure enhance resistance and resilience of soil biological functions against soil disinfection. Biol. Fertil. Soils 43, 349-356. doi:10.1007/s00374-006-0116-3

Wallenius, K., Rita, H., Mikkonen, A., Lappi, K., Lindström, K., Hartikainen, H., Raateland, A., Niemi, R.M., 2011. Effects of land use on the level, variation, and spatial structure of soil enzyme activities and bacterial communities. Soil Biol. Biochem. 43, 1464-1473. doi:10.1016/j.soilbio.2011.03.018

Zimmermann, M., Bird, M.I., 2012. Temperature sensitivity of tropical forest soil respiration increase along an altitudinal gradient with ongoing decomposition. Geoderma 187-188, 8-15. doi:10.1016/j.geoderma.2012.04.015 


\subsubsection{Supporting information}

Table S1 Description of the substrates for estimation of enzyme activities

\begin{tabular}{lll}
\hline Enzyme & Substrate & Buffer
\end{tabular}

C-cycle enzymes

$\beta$-glucosidase

Cellobiohydrolase

Xylanase

\section{$\mathrm{N}$-cycle enzymes}

Chitinase

Leucine 4-methylumbiliferyl-N-acetyl-glucosaminide

L-leucien-7-amido-4-methylcoumarin

L-Tyrosine-7-amido-4-methylcoumarin

TRIZMA 4-methylumbiliferyl- $\beta$-D-glucopyranoside

4-methylumbiliferyl- $\beta$-D-cellobioside

4-methylumbiliferyl- $\beta$-D-xylopyranoside

MES

MES aminopeptidase

Tyrosine

aminopeptidase

\section{P-cycle enzyme}

Acid phosphatase

\section{S-cycle enzyme}

Sulfatase
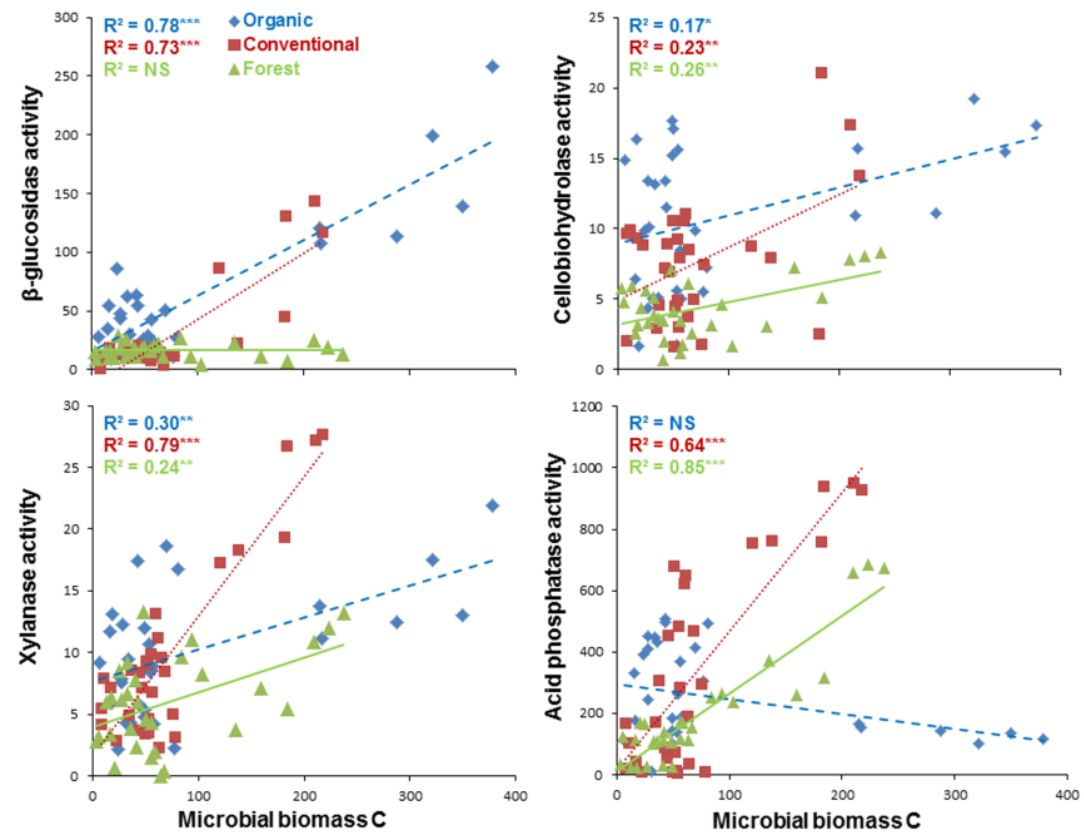

Figure S1 Relationship between the activities of $\beta$-glucosidase, cellobiohydrolase, xylanase, acid phosphatase, and microbial biomass $C$. Microbial biomass $C$ is expressed in $\mu \mathrm{g} \mathrm{C} \mathrm{g}^{-1}$ soil. Enzyme activities are expressed in $\mathrm{nmol} \mathrm{g}{ }^{-1}$ soil $\mathrm{h}^{-1}$. ${ }^{* \star},{ }^{* *},{ }^{*}$ - Significance level at $\mathrm{P}<0.001,<0.01,<0.05$, respectively. NS - not significant. 

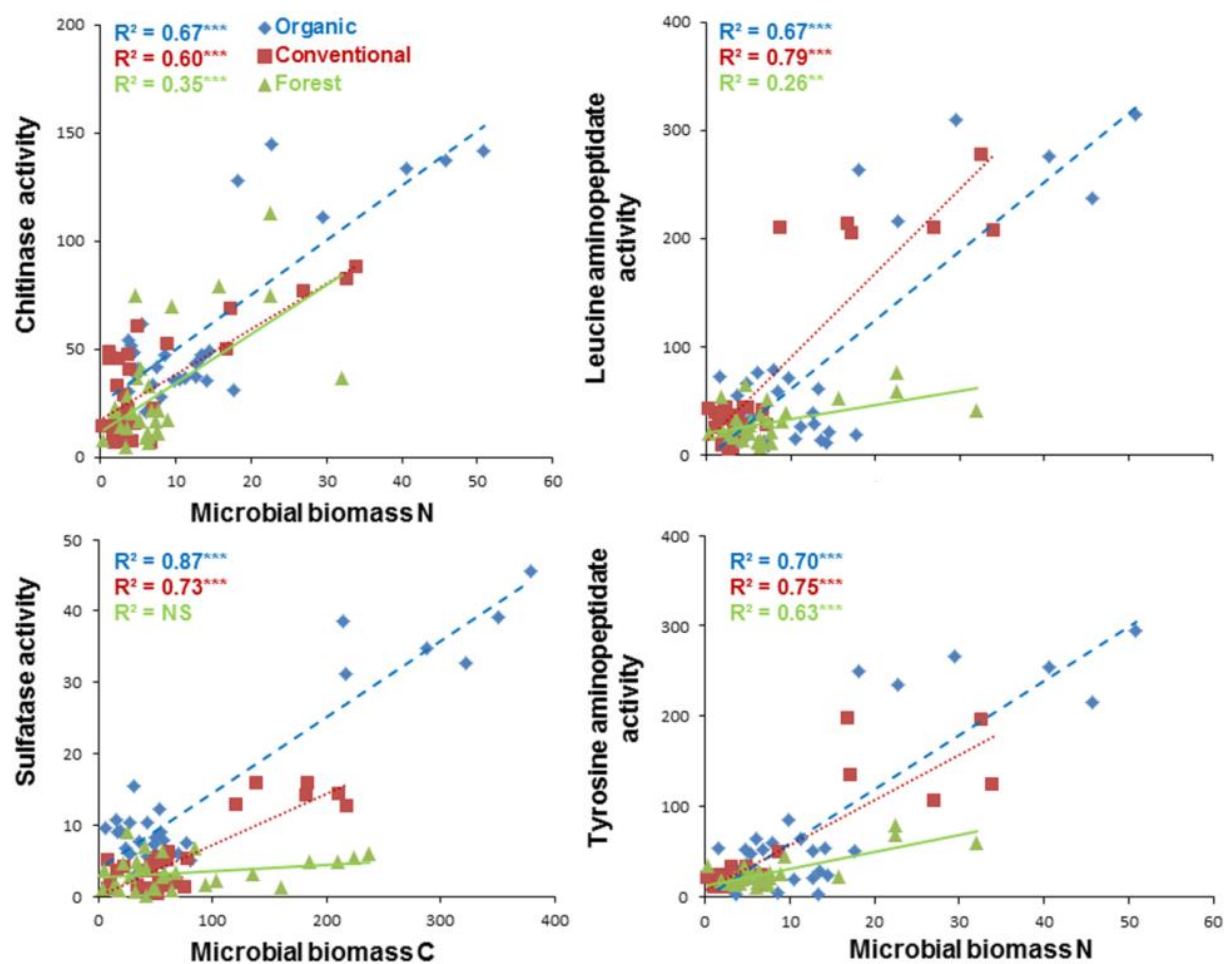

Figure S2 Relationship between the activities of chitinase, leucine aminopeptidase, tyrosine aminopeptidase, and microbial biomass $\mathrm{N}$, and sulfatase with microbial biomass $\mathrm{C}$. Microbial biomass $\mathrm{N}$ and $\mathrm{C}$ are expressed in $\mu \mathrm{g} \mathrm{N} \mathrm{g}^{-1}$ soil and $\mu \mathrm{C} \mathrm{g}^{-1}$ soil, respectively. Enzyme activities are expressed in nmol g-1 soil $\mathrm{h}-1 .{ }^{* * *},{ }^{* *},{ }^{*}$ - Significance level at $\mathrm{P}<0.001,<0.01,<0.05$, respectively. NS - not significant. 


\title{
3.2 Study 2: Phosphorus fractions in subtropical soils depending on land use
}

\author{
Menuka Maharjan $^{1,2,{ }^{*}}$, Deejay Maranguit ${ }^{1,3}$, Yakov Kuzyakov ${ }^{4,5,6}$ \\ Status: Under review on European Journal of Soil Biology \\ ${ }^{1}$ Department of Soil Science of Temperate Ecosystems University of Göttingen, Göttingen, Germany \\ ${ }^{2}$ Institute of Forestry, Tribhuwan University, Hetauda, Makwanpur, Nepal \\ ${ }^{3}$ Department of Soil Science, Visayas State University, Baybay, 6521-A Leyte, Philippines \\ ${ }^{4}$ Department of Agricultural Soil Science, University of Göttingen, Göttingen, Germany \\ ${ }^{5}$ Institute of Environmental Sciences, Kazan Federal University, 420049 Kazan, Russia \\ ${ }^{6}$ Agro-Technology Institute, RUDN University, Moscow, Russia
}

\subsubsection{Abstract}

Land-use change from forest to agriculture, which is driven by the demands of sustaining the growing global population, affects nutrient dynamics and availability in soil. Although phosphorus $(P)$ is one of the main limiting nutrients in agricultural production, little is known about the influence of soil microorganisms on the dynamics of $\mathrm{P}$ cycling in subtropical land use systems. The objective was to assess the impacts of land use on forms and distribution of $P$ depending on microbial activity in soil under different land use system.

Total P stock was highest in organic farming soil followed by conventional farming and forest. Cropping system, crop residue input and farmyard manure application supported high organic matter and microbial biomass content, leading to higher concentrations of soil $P$ under organic farming. The larger fraction of organic $P(P o)$ than inorganic $P(P i)$ implies that total $P$ is regulated by organic $P$ in all three land use systems. Easily-available $P$ fractions (microbial biomass $\mathrm{P}, \mathrm{NaHCO}_{3}-\mathrm{Pi}$ and $\mathrm{Po}$ ), moderately available $\mathrm{P}(\mathrm{NaOH}-\mathrm{Po})$ and non-available $\mathrm{P}(\mathrm{HCl}-\mathrm{Pi}$ and $\mathrm{Po})$ were much higher in organic farming than conventional farming and forest, especially in the topsoil layer. Compared to organic farming, the higher C:Po ratio in conventional farming and forest indicates $P$ limitation. Mineralization of $\mathrm{Po}$ is enhanced to release mineral $\mathrm{P}$, corresponding with the higher activity of acid phosphatase in conventional farming and forest. Concluding, $P$ status is considerably altered by land use and management practices, revealing the significance of soil organic matter in maintaining $P$ reserves.

Key words: Land-use change, phosphorus fractions, carbon-to-phosphorus ratio, acid phosphatase activity, soil organic matter 
Corresponding Author: Menuka Maharjan, menuka48maharjan@gmail.com

\subsubsection{Introduction}

Land-use change, such as conversion of forest to intensively managed agriculture, is the largest global change of the last two centuries due to the increasing demands of feeding the growing human population (Tilman et al., 2001; Geissen et al., 2009a; Guillaume et al., 2015). During the period of $1980-2000$, approximately $50 \%$ of the new arable land came from intact forest, while $28 \%$ came from disturbed forest in the tropics (Lambin and Meyfroidt, 2011). Furthermore, land-use change significantly alters the physical, chemical and biological properties of soil, affecting soil fertility and ultimately reducing the capacity of land for sustainable crop production (Matson, 1997; Geissen et al., 2009; Mganga et al., 2015).

Land-use change has substantial effects on phosphorus $(P)$ availability for plant uptake by increasing $\mathrm{P}$ losses or $\mathrm{P}$ transfer into recalcitrant pools, leading to significant alterations in P distribution and availability (Wright, 2009; Maranguit et al., 2017). The main sources of soil $P$ are either parent material or application of mineral and/or organic fertilizers (Henriquez, 2002). Other than N, P is considered as the largest globally limiting nutrient for food production (George et al., 2006; Dieter et al., 2010 ). P availability may be limited due to 1) inherent characteristics of the parent material 2) strong sorption of $\mathrm{PO}_{4}{ }^{3-}$ to $\mathrm{Al}$ and $\mathrm{Fe}$ (hydro) oxides or 3) a low input of inorganic and organic fertilizers (Solomon et al., 2002). Plants and microorganisms have developed a broad range of mechanisms to enhance the acquisition of $\mathrm{P}$, e.g., production of phosphatase enzymes, which are responsible for hydrolyzing recalcitrant forms of organic $P$ to make it available to plants (Chen et al., 2002; Richardson et al., 2005). Microorganisms play a vital role in $\mathrm{P}$ mineralization from various organic sources (Gressel et al., 1996; Lopez-hernandez et al., 1998) and transformations of soil organic P (Setwart and Tiessen, 1987; Magid et al., 1996; Frossard et al., 2000). Thus, soil microorganisms are a key pool not only of $\mathrm{C}$ and $\mathrm{N}$, but also of $\mathrm{P}$. Furthermore, a majority of the $\mathrm{P}$ held in microorganisms can be released quickly and be readily available for plant growth (Macklon et al., 1997). Previous studies have examined the effects of landuse change on $\mathrm{P}$ forms, distribution along soil depth, availability for plants and long term stability as a consequence of forest conversion to monoculture plantations (Maranguit et al., 2017) mineral and manure fertilization (Motavalli and Miles, 2002; Sharpley et al., 2004; van der Salm et al., 2017), tillage system (O'Halloran, 1993; Selles et al., 1999; Zamuner et 
al., 2008) and cropping/vegetation systems (Zhao et al., 2008; Wright, 2009; Dieter et al., 2010). These studies highlight that the status and distribution of $P$ depends on land use and management practices. Although the effects of management practices on $P$ fractions are intensively discussed, knowledge of the linkage between microbiological processes and $P$ fractions is limited.

Various methods have been developed to determine soil P fractions (Chang and Jackson, 1957; Bowman and Cole, 1978; Hedley et al., 1982; Tiessen and Moir, 1993). Hedley et al., (1982), developed a sequential chemical $P$ fractionation method that extracts various inorganic and organic fractions from labile to stable forms. This has been widely used to investigate soil $P$ fractions and $P$ dynamics (Chimdi et al., 2014). Application of the sequential fractionation technique permits analysis of the specific extractable fractions of $P$ pools to examine the effects of land use and management practices on $P$ dynamics (Hedley et al., 1982; Tiessen et al., 1983). Hedley fractionation is based on the analysis of inorganic phosphorus $(\mathrm{Pi})$ and organic phosphorus $(\mathrm{Po})$ fractions of different availability and chemical binding ability by utilizing extractants of increasing strength (Hedley et al., 1982; Guo et al., 2000). The following fractions are extracted (i) readily available $P$ for plants, i.e., $\mathrm{NaHCO}_{3}-\mathrm{Pi}$ ii) easily mineralizable $\mathrm{P}$, i.e., $\mathrm{NaHCO}_{3}-\mathrm{Po}$ and microbial biomass $\mathrm{P}$ (iii) strongly adsorbed $\mathrm{P}$ by aluminum ( $\mathrm{Al}$ ) and iron (Fe) oxides i.e. $\mathrm{NaOH}-\mathrm{P}$ (iv) $\mathrm{P}$ associated with calcium (Ca-P), considered as non-available $\mathrm{P}$ to plants i.e. $\mathrm{HCl}-\mathrm{P}$.

The study site in "Chitwan district" lies in the Terai region, a plain in southern Nepal. After eradiation of Malaria in the 1950's, a people migration scheme was induced in Terai from Middle Mountain. The region's current population growth rate is $1.75 \%$, the highest in Nepal (FRA/DFRS, 2014). Consequently, massive deforestation has been utilized to support the livelihood of new settlements. Additionally, agricultural intensification through conventional farming was implemented for sustaining food security for the growing population. Most of the studies in Chitwan focused on the effects of land-use change on above and below ground carbon content and stocks (Maharjan et al., 2017). However, studies focused on various $P$ pools and linking the response of microbe-induced $P$ availability to different land use systems is absent. Thus, this calls for evaluation on the effects of land use on $\mathrm{P}$ forms and distribution in subtropical soils.

The objective was to assess the impacts of three land use systems, i.e. organic farming, conventional farming, and forest, on the forms and distribution of soil P. We hypothesized that i) land use affects the availability of inorganic and organic $P$ fractions ii) $P$ stocks, 
microbial $\mathrm{P}$ and acid phosphatase activity are higher in forest followed by organic farming and conventional farming.

\subsubsection{Materials and Methods}

\subsubsection{Site description}

The study was carried out in Chitwan district $\left(27^{\circ} 350 \mathrm{~N} 84^{\circ} 300 \mathrm{E}\right)$ of Nepal. The climate is subtropical with an average temperature of $30^{\circ} \mathrm{C}$ and an average rainfall of $1763 \mathrm{~mm}$ year

1. Three land-use systems were selected (Table 1): forest, organic farming, and conventional farming. Both farming sites were located in Fullbari Village Development Committee (VDC) and the forest site in Patihani VDC. The soils are Gleyic Cambisols (organic farming and forest) and Eutric Cambisol for the conventional farming site (IUSS Working Group WRB, 2015). The soil texture at all sites is sandy loam. The organic farming site has been under organic farming practices for 15 years. The crop rotations are maize + rice + vegetables/mustard, and maize + rice + wheat/lentils for the organic and conventional farms, respectively (Table 1).

The organic farm was under vegetable farming during soil sampling, while the conventional farm was fallow with remaining rice stubbles. Forest is dominated by the broad leaf Shorea robusta commonly known as Sal. The leaves of Sal are collected by local people for performing social and religious activities.

Table 1 Description of land use and soil properties (Ap/Ah horizon)

\begin{tabular}{|c|c|c|c|c|c|}
\hline Land use & Management & Pesticide & $\mathrm{pH}\left(\mathrm{H}_{2} \mathrm{O}\right)$ & $\begin{array}{l}\text { Carbon } \\
\left(\mathrm{mg} \mathrm{C} \mathrm{g}^{-1}\right)\end{array}$ & $\begin{array}{l}\text { Nitrogen } \\
\left(\mathrm{mg} \mathrm{N} \mathrm{g}^{-1}\right)\end{array}$ \\
\hline $\begin{array}{l}\text { Organic farming } \\
=15 \text { years }\end{array}$ & $\begin{array}{l}\text { Farmyard } \\
\text { manure:10 ton } \mathrm{ha}^{-1} \\
\mathrm{yr}^{-1} \\
\text { Vermicomposting }\end{array}$ & No & 7.5 & 21 & 1.9 \\
\hline $\begin{array}{l}\text { Conventional } \\
\text { farming }\end{array}$ & $\begin{array}{l}\text { Urea: } 60 \mathrm{~kg} \mathrm{ha}^{-1} \mathrm{yr}^{-1} \\
\text { Potassium: } 15 \mathrm{~kg} \\
\text { ha }^{-1} \mathrm{yr}^{-1}\end{array}$ & Yes & 5.0 & 15 & 1.2 \\
\hline Forest & $\begin{array}{l}\text { Collection of leaf } \\
\text { litter for social and } \\
\text { religious activities }\end{array}$ & No & 5.5 & 9 & 0.7 \\
\hline
\end{tabular}




\subsubsection{Soil sampling and preparation}

To assess the effects of land use on $P$ fractions, soils from the three land use systems were sampled from 0 to $20 \mathrm{~cm}$ depth at intervals of $10 \mathrm{~cm}$. Plant remains, debris and roots were removed using tweezers. The samples were kept cold (at $4^{\circ} \mathrm{C}$ ) prior to analysis.

22 grams of air-dried soil from each land use system was placed into 100-ml jars. The soil was adjusted to $70 \%$ of the water holding capacity (WHC) and pre-incubated for 14 days at $22^{\circ} \mathrm{C}$ prior to sequential extraction to restore equilibrium following the disturbance of drying and sieving (Hedley et al., 1982).

\subsubsection{Sequential $P$ fractionation}

Various organic and inorganic $P$ fractions were determined in soil via the Hedley et al. (Hedley et al., 1982) sequential fractionation method with the modifications of Tiessen and Moir (Tiessen and Moir, 1993). This method uses extractants of increasing strength to first remove labile $\mathrm{Pi}$ and $\mathrm{Po}$, followed by the stable $\mathrm{P}$ forms (Fig. S1).

Microbial biomass $\mathrm{P}$ (MBP) was determined by chloroform fumigation-extraction (Kouno et al., 1995; Cheesman et al., 2010 modified by Yevdokimov and Blagodatskaya, 2014) . Briefly, approximately 3 grams of soil was placed into a $50-\mathrm{ml}$ centrifuge tube filled with 30 $\mathrm{ml}$ of deionized water for both fumigated and non-fumigated samples. For fumigated samples, $300 \mu \mathrm{l}$ of chloroform was added to the sample. Both fumigated and non-fumigated samples contained one anion exchange membrane (AEM) strip and were kept for $24 \mathrm{~h}$ on an end-to-end mechanical shaker. After shaking, AEM strips were removed and washed three times by gently submerging the strip into deionized water. The AEM strips were subsequently immersed into centrifuge tubes filled with $45 \mathrm{ml}$ of $0.25 \mathrm{M} \mathrm{H}_{2} \mathrm{SO}_{4}$ and were shaken for three hours. Finally, phosphate was measured in the extracts via the malachite green colorimetric method (D'Angelo et al., 2001 modified by Yevdokimov and Blagodatskaya, 2014). Following MBP extraction, the soils were further extracted sequentially for the rest of the $P$ pools. Briefly, 3 grams of soil was placed into a $50-\mathrm{ml}$ centrifuge tube and extracted with the following extractants in sequential order: (i) $30 \mathrm{ml} 0.5$ $\mathrm{M} \mathrm{NaHCO}_{3}$ at $\mathrm{pH}$ 8.5, which extracts relatively labile $\mathrm{Pi}$ and $\mathrm{Po}$ (ii) $30 \mathrm{ml} 0.1 \mathrm{M} \mathrm{NaOH}$, which extracts $\mathrm{Fe}$ and $\mathrm{Al}$ bound $\mathrm{P}$ iii) $30 \mathrm{ml} 1 \mathrm{M} \mathrm{HCl}$, which extracts $\mathrm{Ca}$ bound $\mathrm{P}$. After addition of extractants, samples were shaken for $16 \mathrm{~h}$ and the soil suspensions were centrifuged at $3500 \mathrm{rpm}$ for $15 \mathrm{~min}$. The resulting supernatants were filtered using Whatman no. 42 filter papers and stored in small vials at $4{ }^{\circ} \mathrm{C}$ for $\mathrm{P}$ measurement. 


\subsubsection{Determination of phosphate}

Total P (TP) and Pi were determined directly from the extracts, while Po was calculated as the difference between the TP and Pi. For TP, $5 \mathrm{ml}$ aliquots of each extract were digested by ammonium-persulfate and $\mathrm{H}_{2} \mathrm{SO}_{4}$ to oxidize dissolved $\mathrm{Po}$ to $\mathrm{Pi}$ forms. TP was determined as the concentration of soluble reactive P (Environmental Protection Agency, 1997).

For the measurement of $\mathrm{Pi}$, a $150 \mu \mathrm{l}$ aliquot from each extract was added to a disposable 96-well polystyrene microplate. $30 \mu$ of Reagent 1 (14.2 mmol L-1 ammonium molybdate tetrahydrate $+3.1 \mathrm{M} \mathrm{H}_{2} \mathrm{SO}_{4}$ ) was subsequently added to each sample and the microplate was shaken for $10 \mathrm{~min}$. After shaking, $30 \mu \mathrm{l}$ of Reagent 2 (aqueous polyvinyl alcohol+ deionized distilled water + MG carbinol hydrochloride) was added and the microplate was shaken for an additional $20 \mathrm{~min}$. After shaking, microplates were incubated at $40^{\circ} \mathrm{C}$ for 40 min. Incubated microplates were read on a Victor microplate reader at $630 \mathrm{~nm}$. The microplate was again read after $12 \mathrm{~h}$ for evaluation of the stability of measurements. Simultaneously, standards were prepared with the same extractants as used for extraction of phosphate i.e. $\mathrm{NaHCO}_{3}, \mathrm{NaOH}, \mathrm{HCl}$, and $\mathrm{H}_{2} \mathrm{SO}_{4}$. The standard varied depending on the $\mathrm{P}$ concentration range (D'Angelo et al., 2001 modified by Yevdokimov and Blagodatskaya, 2014)). Values for the residual $P$ fractions and the Po fraction of organic soil at $10-20 \mathrm{~cm}$ were below the detection limit. Thus, they were not considered in the analyses.

\subsubsection{Microbial biomass carbon}

Microbial biomass $\mathrm{C}$ was determined by the chloroform fumigation-extraction method (Vance et al., 1987), based on the difference between $C$ extracted from fumigated and nonfumigated soil samples using $0.05 \mathrm{M} \mathrm{K}_{2} \mathrm{SO}_{4}$. A k $\mathrm{K}_{\mathrm{EC}}$ factor of 0.45 was used to convert microbial C flush into microbial biomass C (Joergensen, 1996).

\subsubsection{Enzyme activities}

The activity of the enzyme targeting P containing organic compounds (acid phosphatase) was assayed using fluorogenically labeled substrates based on 4-methylumbelliferone (MUF) (Pritsch et al., 2004). The MUF substrates were dissolved in 2-methoxyethanol (Hoppe, 1983) and the dissolved substrate was further diluted with sterile water. All chemicals and substrates were purchased from Sigma, Germany.

Briefly, 1 gram of soil from each of the three land uses at $0-10$ and $10-20 \mathrm{~cm}$ was suspended with $50 \mathrm{ml}$ of sterile water using low-energy sonication $\left(40 \mathrm{~J} \mathrm{~s}^{-1}\right.$ output energy 
for $2 \mathrm{~min}$ ). $50 \mu \mathrm{l}$ of the resultant soil suspension was added to $100 \mu \mathrm{l}$ of substrate solution and $50 \mu \mathrm{l}$ of buffer (MES) in a 96-well microplate for $2 \mathrm{~h}$ (Koch et al., 2007). Fluorescence was measured at an excitation wavelength of $355 \mathrm{~nm}$ and an emission wavelength of 460 $\mathrm{nm}$, split width of $25 \mathrm{~nm}$, with a Victor ${ }^{3}$ 1420-050 Multilabel Counter (PerkinElmer, USA). Calibration curves, as well as controls for the autofluorescence of the substrate, were included in every series of enzyme measurement. Enzymes activities were expressed as MUF released in nmol per g dry soil per hour (nmol g ${ }^{-1}$ soil $^{-1}$ ) (Razavi et al., 2015).

\subsubsection{Bulk density and elemental analysis}

Bulk density measured by core sampling method. Cores were inserted horizontally at 0-10 and $10-20 \mathrm{~cm}$ depth from the side of the pit. $40 \mathrm{mg}$ of each air-dried, ground soil sample was weighted into tin capsules and carbon content determined via a Vario Elemental analyzer (Elementar Analysensysteme GmbH, Germany).

\subsubsection{Data analysis}

$P$ fractions were expressed as the mean of the four field replicates and were presented in $\mathrm{mg} \mathrm{P} \mathrm{kg}{ }^{-1}$ soil. $\mathrm{P}$ stocks presented in $\mathrm{kg} \mathrm{P} \mathrm{ha}^{-1}$ were calculated for the soil depth intervals 0-10 and 10-20 cm using the following equation (Maranguit et al., 2017):

$S=x^{*} \rho^{*} Z$

where $\mathrm{S}$ is the $\mathrm{P}$ stock for fixed depths and $(\mathrm{x})$ is the soil $\mathrm{P}$ content at the selected depth $(\mathrm{z})$, and $\rho$ is the soil bulk density.

The effects of land use on microbial $\mathrm{P}, \mathrm{P}$ fractions, total $\mathrm{P}$ content, $\mathrm{P}$ stocks, C/P ratio and phosphatase activity were analyzed using one-way analysis of variance (ANOVA) using the statistical software Statistica 12. Homogeneity was met by log transformation of the data (Total Pi, Total Po and P stock at 10-20 cm depth). Differences between land uses and between depths are accepted as significant at $p<0.05$.

\subsubsection{Results}

\subsubsection{Microbial biomass carbon and phosphorus}

Compared with conventional farming and forest, organic farming resulted in higher microbial $C$ at both soil depths (350 and $240 \mu \mathrm{g} \mathrm{g}^{-1}$ soil, respectively at $0-10$ and $10-20 \mathrm{~cm}$ 
depth) (Fig. 1, Maharjan et al., 2017, modified). Similarly, microbial biomass P was higher (3.6 and $1.0 \mathrm{mg} \mathrm{P} \mathrm{kg}^{-1}$ at $0-10$ and $10-20 \mathrm{~cm}$ depth, respectively) in organic farming compared to conventional farming and forest at both depths (Fig. 1). Microbial $\mathrm{C}$ and $\mathrm{P}$ contents for conventional farming and forest were not significantly different.
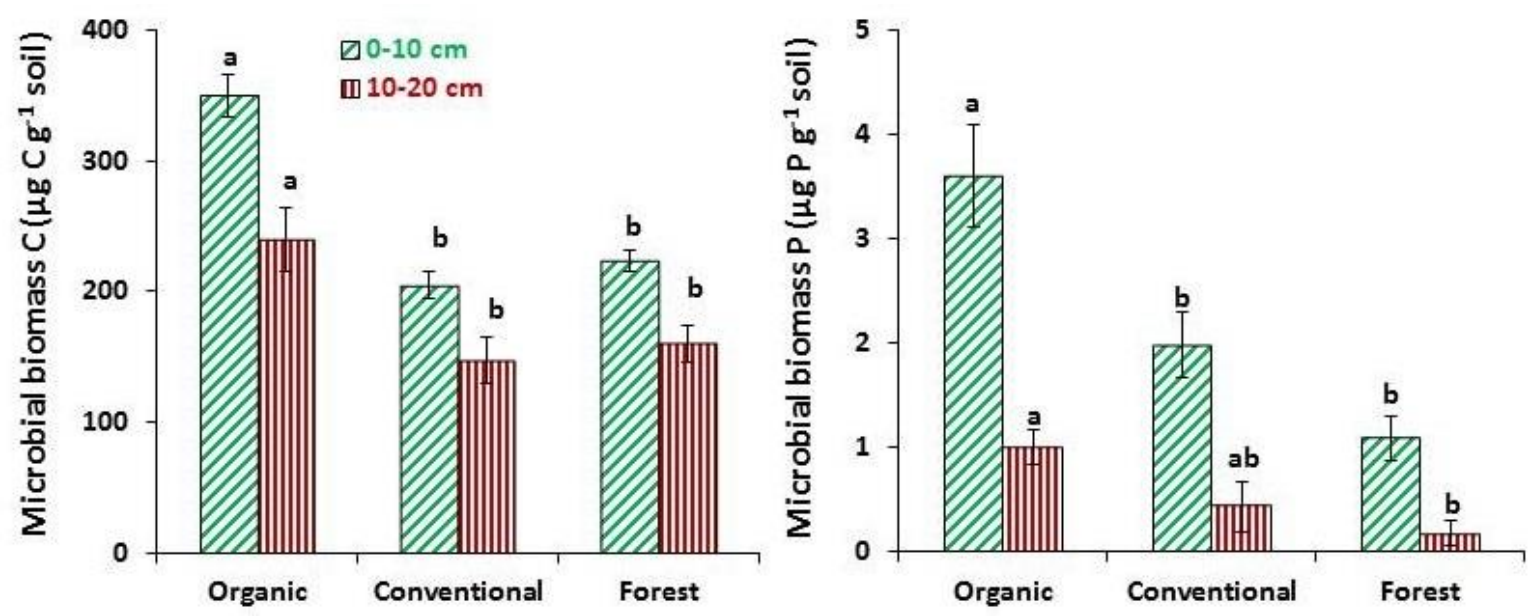

Figure 1 Microbial biomass carbon ( $\mathrm{mg} \mathrm{C} \mathrm{g}^{-1}$ ) (Maharjan et al. 2017, modified) and Phosphorus (mg $P \mathrm{~kg}^{-1}$ ) depending on land use. Values represent means \pm SE $(n=4)$. Means followed by different letters within the same depth differ significantly $(p<0.05)$.

\subsubsection{Total phosphorus content and phosphorus stocks}

Total Pi constituted between $58 \%$ and $82 \%$ of total P. Total Po represented between $18 \%$ and $42 \%$ of total $\mathrm{P}$ (Fig. 2). Total $\mathrm{Pi}$ and $\mathrm{Po}$ was higher in organic farming than conventional farming and forest and declined with depth in all soils. After conversion of forest, the $P$ stock in soil under organic farming significantly increased by $373 \%$ and $170 \%$ at $0-10$ and $10-20 \mathrm{~cm}$ depth, respectively (Fig. 2). The resulting increase was much lower under conventional farming compared to forest $(64 \%$ and $36 \%$ at $0-10 \mathrm{~cm}$ and $10-20 \mathrm{~cm}$ depth, respectively). Overall, our results indicate that $\mathrm{P}$ stocks are strongly altered by landuse change. 

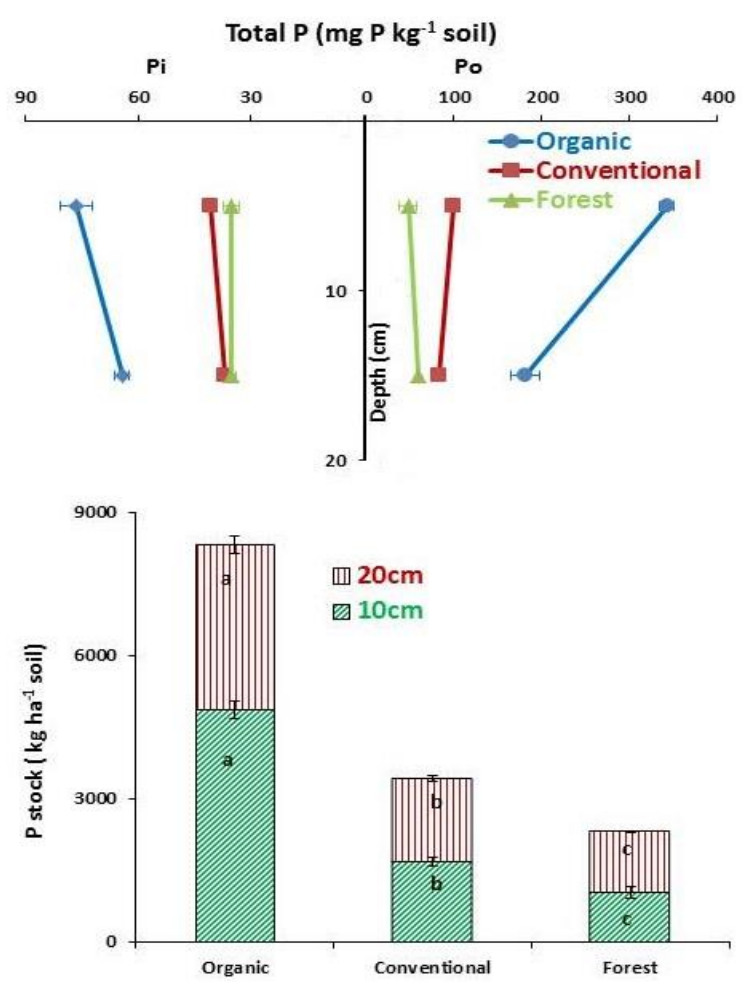

Figure 2 Total content of organic and inorganic $\mathrm{P}\left(\mathrm{mg} \mathrm{P} \mathrm{kg}^{-1}\right)$ (top) and $\mathrm{P}$ stocks $\left(\mathrm{kg} \mathrm{P} \mathrm{ha}^{-1}\right)$ (bottom) depending on land use. Values represent means $\pm \operatorname{SE}(n=4)$. Means followed by different letters within the same depth differ significantly $(p<0.05)$.

\subsubsection{Phosphorus fractions in soil}

Easily available $\mathrm{Pi}$, i.e., $\mathrm{NaHCO}_{3}-\mathrm{Pi}$, was higher in organic farming $\left(21 \mathrm{mg} \mathrm{P} \mathrm{kg}^{-1}\right.$ soil at 0 $10 \mathrm{~cm}$ depth) followed by conventional farming (11 $\mathrm{mg} \mathrm{P} \mathrm{kg}^{-1}$ soil at $0-10 \mathrm{~cm}$ depth) and forest (1 $\mathrm{mg} \mathrm{P} \mathrm{kg}^{-1}$ soil at $0-10 \mathrm{~cm}$ depth) (Fig. 3). A similar trend was observed at 10-20 $\mathrm{cm}$ depth in all three land uses. Similar to $\mathrm{NaHCO}_{3}-\mathrm{Pi}$, the highest $\mathrm{NaHCO}_{3}-\mathrm{Po}$ was found in organic farming $\left(10 \mathrm{mg} \mathrm{P} \mathrm{kg}^{-1}\right.$ soil in 0-10 cm). However, conventional farming and forest soils had similar $\mathrm{NaHCO}_{3}$-Po. In contrast, $\mathrm{NaHCO}_{3}-\mathrm{Po}$ at $10-20 \mathrm{~cm}$ was highest in conventional farming, while the content of $\mathrm{NaHCO}_{3}-\mathrm{Po}$ was similar in organic farming and forest. Moderately-available $\mathrm{Pi}(\mathrm{NaOH}-\mathrm{Pi})$ was higher in forest $\left(26 \mathrm{mg} \mathrm{P} \mathrm{kg}^{-1}\right.$ soil) than organic farming (22 $\mathrm{mg} \mathrm{P} \mathrm{kg}^{-1}$ soil). However, $\mathrm{NaOH}-\mathrm{Pi}$ had same content at $10-20 \mathrm{~cm}$ depth under different land use system. Moderately-available $\mathrm{Po}(\mathrm{NaOH}-\mathrm{Po})$ was highest in organic farming (82 $\mathrm{mg} \mathrm{P} \mathrm{kg}^{-1}$ soil) and lowest in forest (10 mg $\mathrm{P} \mathrm{kg}{ }^{-1}$ soil). On the other hand, moderately-available Po at 10-20 cm depth followed the order: conventional farming $=$ organic farming $>$ forest. The content of non-available $\mathrm{P}(\mathrm{HCl}-\mathrm{Pi}$ and $\mathrm{Po})$ ranged from 34$247 \mathrm{mg} \mathrm{P} \mathrm{kg}^{-1}$ soil in organic farming across both depths. Non-available $P$ content was similar for conventional farming and forest. Non-available P notably increased (69-590\%) 
under organic farming and decreased by $7-44 \%$ under conventional farming (except 0-10 $\mathrm{cm}$ ) compared to native forest. Consequently, land use had significant effects on microbial $\mathrm{P}$ and on $\mathrm{Pi}$ and $\mathrm{Po}$ fractions (available, moderately-available and non-available), and these effects were more prominent in the topsoil.

Easily-available $\mathrm{P}\left(\mathrm{mg} \mathrm{kg}^{-1}\right.$ soil)

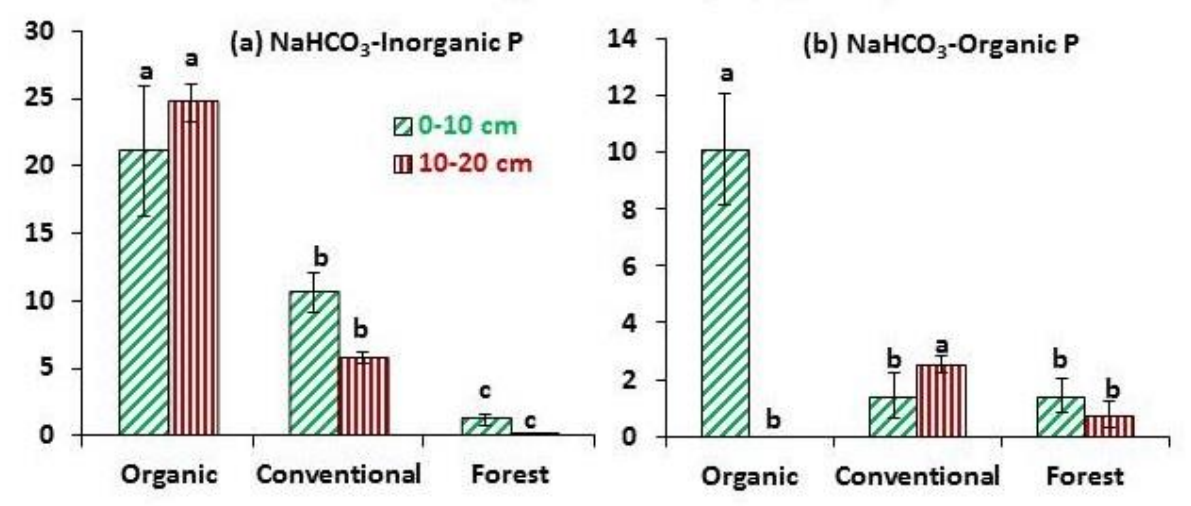

Moderately-available $\mathrm{P}\left(\mathrm{mg} \mathrm{kg}^{-1}\right.$ soil)
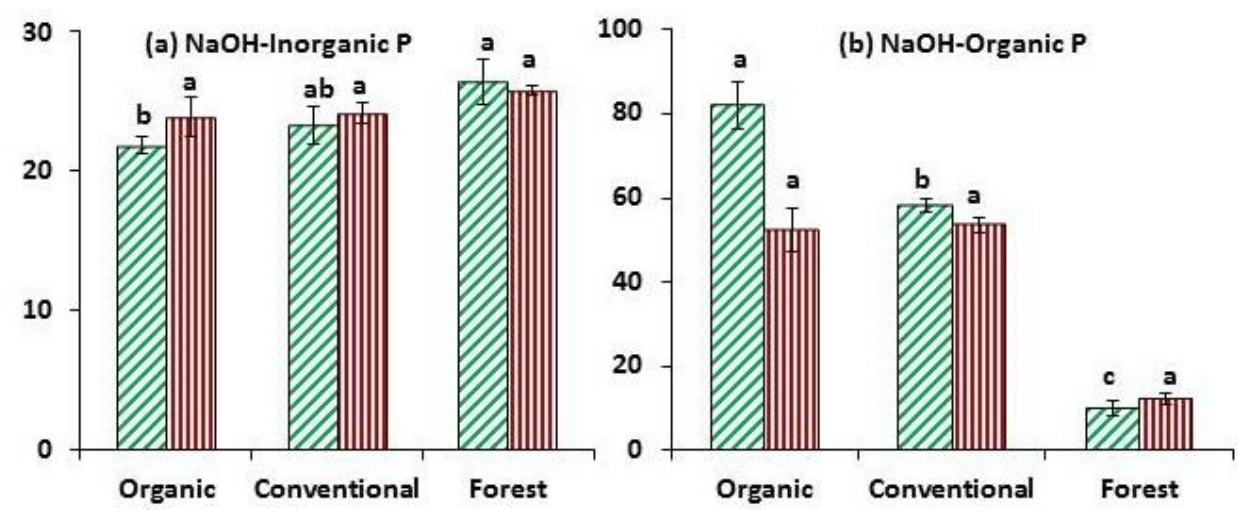

Non-available $\mathbf{P}\left(\mathrm{mg} \mathrm{kg}^{-1}\right.$ soil)
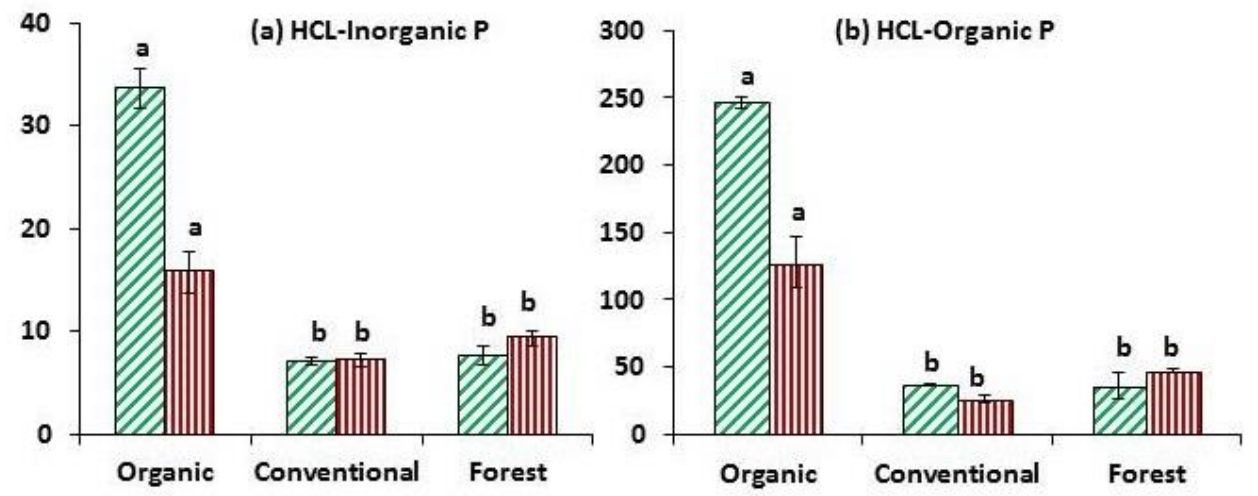

Figure 3 Inorganic and organic soil phosphorus fractions $\left(\mathrm{mg} \mathrm{P} \mathrm{kg}^{-1}\right)$ depending on land use. Values represent means \pm SE $(n=4)$. Means followed by different letters within the same depth differ significantly $(p<0.05)$. 


\subsubsection{Carbon to phosphorus ratios and phosphatase activity}

The carbon to organic P (C: Po) ratio ranged between 61 and 202, with the lowest values occurring in soils with the highest total soil P (Fig. 4). The highest (202) and lowest ratio (61) was detected in the topsoil layers under forest and organic farming, respectively. The ratio declined with depth in conventional farming and forest, whereas it increased in organic farming. Thus, there was no definite pattern of C:Po ratio with depth.

The potential activity of acid phosphatase at $0-10 \mathrm{~cm}$ was higher under conventional farming (911 $\mathrm{nmol} \mathrm{g}^{-1}$ soil h$\left.^{-1}\right)$ followed by forest $\left(256 \mathrm{nmol} \mathrm{g}^{-1}\right.$ soil $\left.^{-1}\right)$ and organic farming $\left(116 \mathrm{nmol} \mathrm{g}^{-1}\right.$ soil $^{-1}$ ) (Fig. 4). A similar trend was observed at 10-20 cm depth in all soils.
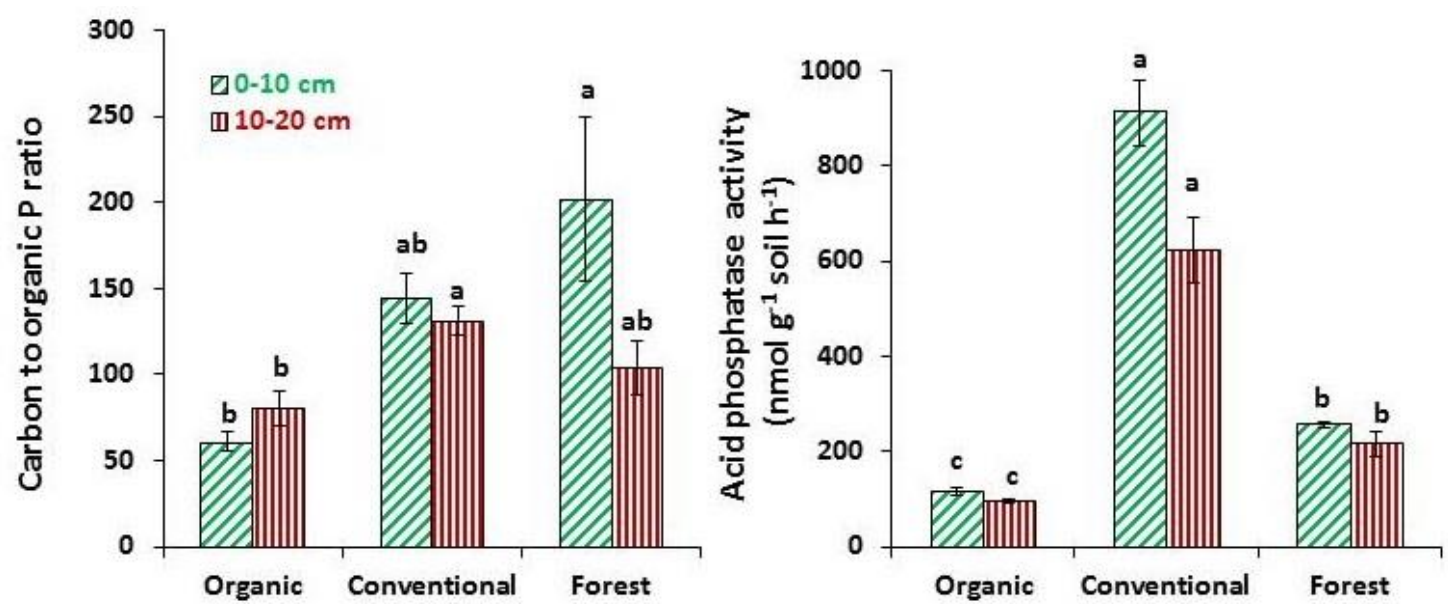

Figure 4 Ratio of soil carbon to organic phosphorus and acid phosphatase activity (nmol g ${ }^{-1}$ soil h$^{-1}$ ) depending on land use. Values represent means \pm SE $(n=4)$. Means followed by different letters within the same depth differ significantly $(p<0.05)$.

\subsubsection{Discussion}

\subsubsection{Phosphorus status is influenced by land use}

Land-use type and management greatly influence $P$ status in the soil. Total $P$ which is an indicator of long-term $P$ sustainability, especially for highly weathered tropical and subtropical soils, was affected by land-use. The high total $\mathrm{P}$ content and $\mathrm{P}$ stocks found under organic farming (Fig.2) was due to the high application of farmyard manure as an organic fertilizer, which was continuously applied for almost 15 years, as well as the influence of the cropping system (Table 2, Fig.5) (Aslam et al., 1999; Daroub et al., 2000; Solomon et al., 2002). These changes resulted in enhanced microbial activity, including immobilization of $\mathrm{P}$, which resulted in higher microbial biomass $\mathrm{P}$ with organic farming. This $P$ immobilization by microorganisms sustains long-term $P$ availability after microbial biomass turnover (Condron and Tiessen, 2005). Likewise, the relatively large fraction of 
total Po extracted with $\mathrm{HCl}$, which is not available for plant uptake, is a very important $\mathrm{P}$ reserve. This will buffer $P$ availability once $P$ in the soil is insufficient for plant growth (Maranguit et al., 2017). This is possible through mineralization of organic $P$ by phosphatases phosphatases (Chen et al., 2002; Castillo and Wright, 2008). The low total Po content in conventional farming and forest compared to organic farming (Fig.2) is due to the reduction of SOM in parallel with increasing mineralization of organic $P$ (Fig.4) (Schoenau et al., 1989; Solomon et al., 2002). Fallow periods and less input of crop residue under conventional farming, and lack of leaf litter input under forest, leads to decreases in SOM content. The addition of fertilizers in conventional farming enhances $P$ availability for biological uptake (plant and microorganisms). However, it is not sustainable in the long run, as this additional $P$ is exported or lost during yield harvest (Schoenau et al., 1989). While, fertilization in conventional farming may stimulate production of Po through microbial P immobilization (Stewart and Sharpley, 1987), which is reflected in increased MBP, the MBP content of conventional farming is still lower than under organic farming (Fig.1). Poor regeneration and low canopy cover in forest exposes the soil surface to sunlight and monsoon rainfall, making it more vulnerable to erosion. Intensive monsoon rainfall could erode soil, removing topsoil along with SOM and added fertilizer under forest and conventional farming, respectively (Shih et al., 1982). A combination of declining crop residue or leaf litter and increased soil erosion leads to reduction of $P$ stocks under conventional farming and forest (Table 2, Fig.5) (Chimdi et al., 2014; Wright, 2009; Solomon et al., 2002).

The $P$ status is particularly dependent on management practices i.e. cropping system, fertilization, residue management practice and tillage operation (Table 2, Fig. 5) (Motavalli and Miles, 2002; Solomon et al., 2002; Wright, 2009).

\subsubsection{Forms and distribution of soil $P$}

The higher content of easily- available $\mathrm{Pi}\left(\mathrm{NaHCO}_{3}-\mathrm{Pi}\right.$; Fig. 3) and -mineralizable Po (i.e. $\mathrm{NaHCO}_{3}$-Po and MBP; Fig. 1 and 3, respectively) under organic farming compared to other land use systems (Fig. 3) can be explained by the continuous application of farmyard manure. Application of organic fertilizers provides readily available $\mathrm{N}$ to plants, which increases plant biomass. As a result, more crop residues are incorporated, resulting in accumulation of organic matter (C and N) (Paniagua et al., 1995; Roldán et al., 2005). This provides a suitable environment for microorganisms and supports higher microbial activity, as soil organic $\mathrm{C}$ is an important source of energy for microorganisms (Blagodatskaya et 
al., 2007; Zamuner et al., 2008; Diacono and Montemurro, 2010). Higher microbial biomass contributes to increasing Po mineralization, resulting in higher availability of organic and inorganic $P$ under organic farming especially in the topsoil (Fig. 1, 3 and 5) (Cooperband, 1992; Paniagua et al., 1995; Motavalli and Miles, 2002). Under conventional farming, the application of pesticides suppressed microbial biomass $C$ and $P$ accumulation (Table 1, Fig. 1) (Oberson et al., 1996). However, application of mineral fertilizers can contribute to Pi availability under conventional farming (Neufeldt et al., 2000). Under forest, the lower availability of easily-available P can be attributed to leaf litter collection (Maranguit et al., 2017 ) by villagers for performing social and religious activities. Additionally, the absence of fertilizer application leads to further reductions in availability of easily-available $P$ compared with other land use systems (Table 2, Fig. 5). Depletion of $\mathrm{NaHCO}_{3}-\mathrm{Po}$, especially in the topsoil, is due to $\mathrm{P}$ losses related to higher crop yields under conventional farming than under organic farming (Guo et al., 2000).

Moderately-available $\mathrm{P}(\mathrm{NaOH}$-extractable $\mathrm{P})$ involves long-term transformation of soil $\mathrm{P}$ to mostly absorbed forms associated with Al and Fe oxides (Hedley et al., 1982; Tiessen et al., 1984; Schoenau et al., 1989). Reduction of moderately-available $\mathrm{Po}(\mathrm{NaOH}-\mathrm{Po})$ in conventional farming and forest (Fig. 3 ) is associated with low SOM levels resulting from the export of plant biomass during yield harvest and collection of leaf litter for religious activities, respectively (Table 2, Fig. 5). Under forest, the pattern of $P$ cycling depends on differences in aboveground biomass compared to agroforestry systems (Chacón and Dezzeo, 2004). As litter input is lower under forest compared to organic farming, the soil capacity to retain $\mathrm{P}$ in the form of $\mathrm{NaOH}$-extractable $\mathrm{Po}$ is diminished (Zamuner et al., 2008). However, the Po content was 2-4 times higher than Pi content in organic and conventional farming soil, indicating the importance of $P o$ as a $P$ reserve in these land use systems. Altogether, $\mathrm{Po}$ is involved in the long-term transformation of soil $\mathrm{P}$ and in $\mathrm{P}$ cycling when soil Pi reserves are limited (Buehler et al., 2002).

Ca-bound $\mathrm{P}$ extracted by $\mathrm{HCl}$ is regarded as more stable pool than other $\mathrm{P}$ fractions (Diaz et al., 2006). Ca-bound $P$ is considered non-available for plant growth. However, nonavailable $P$ can become available for plants following desorption from Ca-bound compounds (Maranguit et al., 2017). Some plants produce specialized roots structures (e.g., cluster roots) that produce large amounts of carboxylates, which release $P$ from strongly-sorbed forms (Lambers et al., 2008), thus allowing plants to mine desorbed P. Certain bacteria and plants have been shown to secrete low-molecular-weight-complexing molecules, such as organic acids, to increase the solubility/dissolution of inorganic P-bound 
molecules (Hayes et al., 2000; George et al., 2004; Richter et al., 2006). Depletion of HCl-P under conventional farming compared with organic farming could be the result of intensive cropping and tillage (Guo et al., 2000; Zamuner et al., 2008). Intensive cropping with frequent tillage operation reduces masses of macroaggregates (Cabria et al., 2005) and decreases the concentration of $\mathrm{Ca}$ bound $\mathrm{P}$. This leads to high levels of $\mathrm{P}$ mining. Considerably higher (4-8 times) fractions of non-available Po than $\mathrm{Pi}$ fractions were observed in organic farming soil than in the other soils (Fig. 3). Land-use change from forest to organic farming increases non-available Po, especially in the topsoil. The decrease of non-available Po with depth under all land use systems corresponds with a decline in soil organic matter (SOM), which is major source of $P$ when mineralized (Magid, 1993; Sarapatka, 2003; Maranguit et al., 2017). This demonstrates the significance of SOM for sustaining fertility in land use stems (Tiessen et al., 1994). Altogether, the fraction of inorganic and organic $P$ forms is highly influenced by land use and management practices (Table 2, Fig. 5).

\subsubsection{Carbon to phosphorus rations and enzyme activity}

The ratio of soil organic $C$ to organic $P(C: P o)$ can be used to estimate $P$ mineralization (Solomon et al., 2002; Chacón et al., 2005). Plants and microorganisms can mineralize organic $P$ by synthesizing phosphatase enzymes according to the $P$ requirement (McGill and Cole, 1981; Dieter et al., 2010). Sufficient concentrations of available $P$ for plant growth suppresses the production of phosphatase and the mineralization of organic $P$, leading to the accumulation soil organic $P$ and a diminishing C:Po ratio (Zhao et al., 2008; Dieter et al., 2010). However, limitations in available $P$ for plant growth triggers phosphatase synthesis, which promotes $P$ mineralization compared to $C$ and results in an increased C:Po ratio (McGill and Cole, 1981; Dieter et al., 2010; Spohn and Kuzyakov, 2013).

If soil has sufficient available phosphate, the C:Po ratio is $<100$, while a ratio of $>200$ indicates insufficient phosphate availability (Smeck, 1985; Dieter et al., 2010). The C: Po ratio of soils ranged from 61-80 in organic soil, 131-144 in conventional farming soil and 104-202 in forest soil (Fig. 4). C: Po ratios in organic farming soil were below 100, indicating a strong effect of farmyard manure. However, the $\mathrm{C}$ : Po ratios in conventional farming and forest soils are higher (>100), implying $P$ limitations of $P$ especially in forest soils. Thus, mineralization of organic $P$ occurs under these land use systems to release mineral P (Frossard et al., 2000; Allison and Vitousek, 2005; Frank and Groffman, 2009). 
This is evidenced by higher acid phosphatase activity under conventional farming and forest compared to organic farming (Fig. 4). As organic farming practices provide ample available $P$, this soil has the lowest acid phosphatase activity, indicative of low $P$ demand (Smeck, 1985; Oberson et al., 2001). Although $P$ limitation is more prominent under forest, acid phosphate activity was higher in conventional farming soil than forest soil. This discrepancy can be explained by the effect of the cropping system. Demand for available P is higher under conventional farming than forest due to the regular cultivation of crops (Fig. 5). Additionally, microbial biomass $P$ is higher in conventional farming, suggesting that microorganisms enhance the production of acid phosphatase to supply $P$ for plant growth (Oberson et al., 1993; Oberson et al., 2001). This shows that microorganisms play key role in the mineralization of organic $\mathrm{P}$ and, consequently, the availability of soil $\mathrm{P}$.

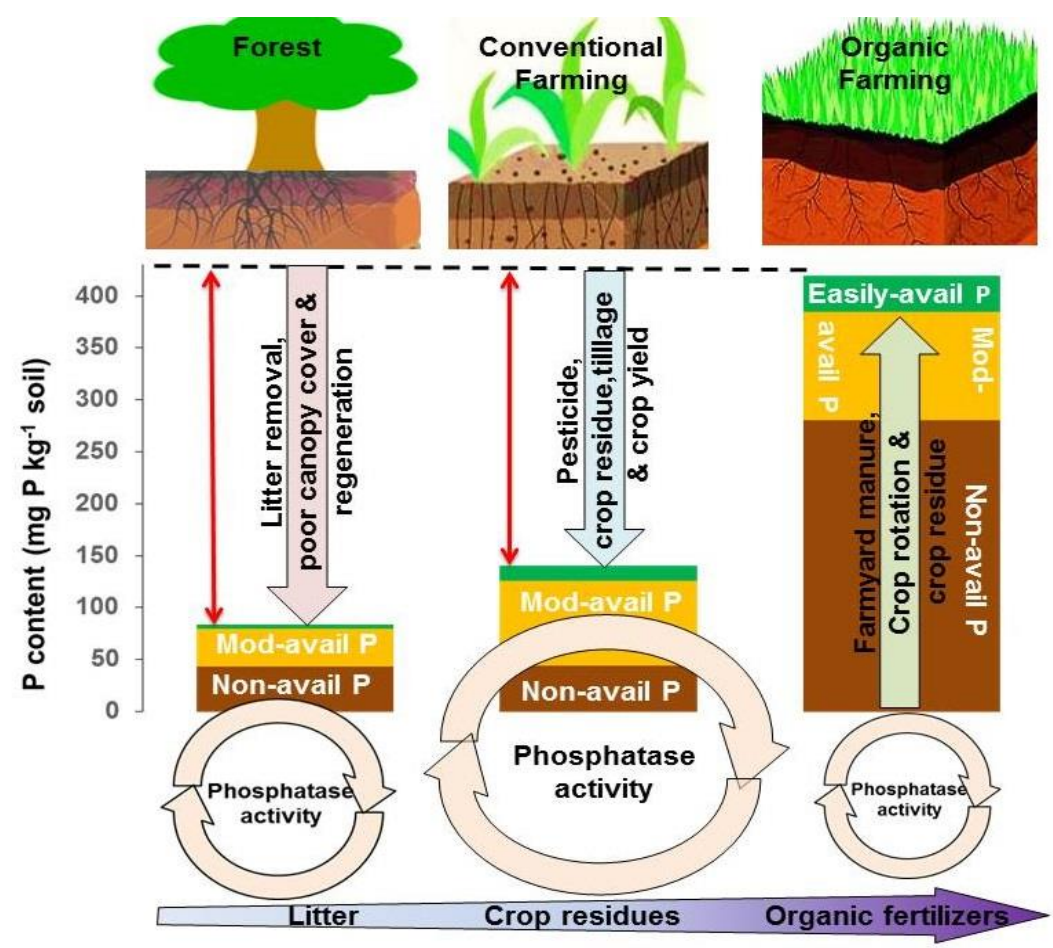

Figure 5 conceptual diagrams representing the effects of land use on soil phosphorus. Colors: green=easily-available phosphorus, yellow=moderately-available phosphorus, brown $=$ non-available phosphorus. Olive color upward arrow represents factors contribution for increasing different fractions of phosphorus in soil under organic farming. Light blue and light pink downward arrows indicates factors responsible for decreasing different fractions of phosphorus in soil under conventional farming and forest, respectively. The double circle arrows (peach color) indicate the phosphate activity. Color intensity of horizontal arrow i.e. light to dark purple represents the lower to higher status of phosphorus stock in soil under forest conventional farming and organic farming. Litter, crop residue and organic fertilizers are dominant factor controlling the soil phosphorus stock in forest, conventional farming and organic farming, respectively. Red line ( - ) shows P losses after land-use change. 


\subsubsection{Conclusions}

The distribution of soil $P$ among various inorganic and organic $P$ forms was strongly influenced by land use. P stock was highest under organic farming and lowest under forest. Soil concentrations of Po were higher than Pi under all land-use systems. Po was primarily composed of $\mathrm{HCl}-\mathrm{Po}$ and $\mathrm{NaOH}-\mathrm{Po}$, with $\mathrm{NaHCO}_{3}-\mathrm{Po}$ comprising a small fraction, indicating that availability of total $P$ is low. Organic matter input, i.e., farmyard manure, crop rotation, and incorporation of residue, are the key factors responsible for the high $\mathrm{P}$ content under organic farming. Lack of continuous cropping, of residue incorporation or of litter input are responsible for declining SOM concentrations, and consequently low $\mathrm{P}$ content, under conventional farming and forest. The relationship between the C: Po ratio and phosphatase activity elucidates the limitation of $P$ under conventional farming and forest, leading to enhanced production of acid phosphatase activity. Overall, the observed differences in the distribution and amounts of $P$ reflect the importance of SOM and microbial biomass for maintaining $P$ reserves in subtropical soils.

\subsubsection{Acknowledgement}

We acknowledge the Erasmus mundus (Experst4Asia) for financial support of Menuka Maharjan and Deejay Maranguit. The authors would like to thank Karin Schmidt and Anita Kriegel for laboratory assistance, and Sandesh Bhatta and Bibek Thapa for field work assistance. The publication was supported by the Government Program of Competitive Growth of Kazan Federal University and with the support of the "RUDN University program 5-100".

\subsubsection{References}

Allison, S.D., Vitousek, P.M., 2005. Responses of extracellular enzymes to simple and complex nutrient inputs. Soil Biol. Biochem. 37, 937-944. https://doi.org/10.1016/j.soilbio.2004.09.014

Aslam, T., Choudhary, M.A., Saggar, S., 1999. Tillage impacts on soil microbial biomass C, N and P, earthworms and agronomy after two years of cropping following permanent pasture in New Zealand. Soil Tillage Res. 51, 103-111. https://doi.org/10.1016/S0167-1987(99)00032-X

Blagodatskaya, E.V., Blagodatsky, S.A., Anderson, T.-H., Kuzyakov, Y., 2007. Priming effects in Chernozem induced by glucose and $\mathrm{N}$ in relation to microbial growth strategies. Appl. Soil Ecol. 37, 95-105. https://doi.org/10.1016/j.apsoil.2007.05.002

Bowman, R.A., Cole, C.V., 1978. An exploratory method for fractionation of organic phosphorus from grassland soils. Soil Sci. 164, 95-101.

Buehler, S., Oberson, A., Rao, I.M., Friessen, D.K., Frossard, E., 2002. Sequential phosphorus extraction of a 33P-labeled oxisol under contrasting agricultural systems. Soil Sci. Soc. Am. J. $66,868-877$. 
Cabria, F.N., Rosa, M., Clara, M., Ciencias, F. De, Unmdp, A., Balcarce, C.C., Aires, B., 2005. O ' xidos de Fe libre asociados a carbono or'nico en agregados de suelos del partido de Balcarce. Free iron oxides associated to organic carbon in soil aggregates in Balcarce county. Cienc. del Suelo 23, 23-29.

Castillo, M.S., Wright, A.L., 2008. Microbial Activity and Phosphorus Availability in A Subtropical Soil under Different Land Uses. World Jounal Agric. Sci. 4, 314-320.

Chacón, N., Dezzeo, N., 2004. Phosphorus fractions and sorption processes in soil samples taken in a forest-savanna sequence of the Gran Sabana in southern Venezuela. Biol. Fertil. Soils 40, 14-19. https://doi.org/10.1007/s00374-004-0733-7

Chacón, N., Dezzeo, N., Muñoz, B., Rodríguez, J.M., 2005. Implications of soil organic carbon and the biogeochemistry of iron and aluminum on soil phosphorus distribution in flooded forests of the lower Orinoco River, Venezuela. Biogeochemistry 73, 555-566. https://doi.org/10.1007/s10533-004-1773-7

Chang, S.C., Jackson, M.L., 1957. Fractionation of soil phosphorus. Soil Sci 84, 133-144.

Cheesman A.W., Turner B.L., Reddy, K.., 2010. Interaction of phosphorus compounds with anionexchange membranes: implications for soil analysis. Soil Sci. Soc. Am. J. 74, 1607-1612.

Chen, C.R., Condron, L.M., Davis, M.R., Sherlock, R.R., 2002. Phosphorus dynamics in the rhizosphere of perennial ryegrass (Lolium perenne L.) and radiata pine (Pinus Radiata D. Don.). Soil Biol. Biochem. 34, 487-499. https://doi.org/10.1016/S0038-0717(01)00207-3

Chimdi, A., Esala, M., Ylivainio, K., 2014. Sequential fractionation patterns of soil phosphorus collected from different land use systems of Dire Inchine District, West Shawa Zone,. J. Amer-Eura Sci. 9, 51-57.

Condron, L.M., Tiessen, H., 2005. Interactions of organic phosphorus in terrestrial ecosystems., in: D.S. (Eds.), I.P.I.T.B.L.F.E.B., Environment, L.A. and the (Eds.), Inositol Phosphates: Linking Agriculture and the Environment. CAB International, Wallingford, UK, p. 295-308.

Cooperband, L.R., 1992. Soil phosphorus dynamics in a humid tropical silvopastoral system. Ph.D thesis. The Ohio State University,U.S.A.

D'Angelo, E., Crutchfield, J., Vandiviere, M., 2001. Rapid, sensitive, microscale determination of phosphate in water and soil. J. Environ. Qual 30, 2206-2209.

Daroub, S.H., Pierce, F.J., Ellis, B.G., 2000. Phosphorus fractions and fate of phosphorus-33 in soils under plowing and no tillage. Soil Sci. Soc. Am. J. 64, 170-176.

Diacono, M., Montemurro, F., 2010. Long-term effects of organic amendments on soil fertility. A review. Agron. Sustain. Dev. M., Montemurro, F. (2010). Long-term Eff. Org. Amend. soil Fertil. A Rev. Agron. Sustain. Dev. 30(2), 401-422. http//doi.org/10.1051/agro/2009040ment 30, 401-422. https://doi.org/10.1051/agro/2009040

Diaz, O.A., Darouba, S.H., Stucka, J.D., Clarkb, M.W., Langa, T.A., Reddy, K.R., 2006. Sediment Inventory and Phosphorus Fractions for Water Conservation Area Canals in the Everglades. Soil Sci Soc Am J 70, 863-871.

Dieter, D., Elsenbeer, H., Turner, B.L., 2010a. Phosphorus fractionation in lowland tropical rainforest soils in central Panama. Catena 82, 118-125. https://doi.org/10.1016/j.catena.2010.05.010

Dieter, D., Elsenbeer, H., Turner, B.L., 2010b. Phosphorus fractionation in lowland tropical rainforest soils in central Panama. Catena 82, 118-125. https://doi.org/10.1016/j.catena.2010.05.010

Environmental Protection Agency, 1997. Methods of Chemical Analysis of Water and Wastes. Environmental Protection Agency, Cincinnati, Ohio.

FRA/DFRS, 2014. Terai Forests of Nepal (2010-2012). Babarmahal, Kathmandu:Forest Resources Assessment Nepal Project/Deparment of Forest Research and Survey.

Frank, D., Groffman, P.., 2009. Plant rhizospheric N processes: what we don't know and why we should care. Ecol. I N 90, 1512-1519. 
Frossard, E., Condron, L.M., Oberson, A., Sinaj, S., Fardeau, J.C., 2000. Processes governing phosphorus availability in temperate soils. J. Environ. Qual. 29, 15-23.

Frossard, E., Condron, L.M., Oberson, A., Sinaj, S., Fardeau, J.C., 2000. Processes Governing Phosphorus Availability in Temperate Soils. Jounrla Envionemntal Qual. 29, 15-23.

Geissen, V., Sánchez-hernández, R., Kampichler, C., Ramos-reyes, R., Sepulveda-lozada, A., 2009. Geoderma Effects of land-use change on some properties of tropical soils - An example from Southeast Mexico. Geoderma 151, 87-97. https://doi.org/10.1016/j.geoderma.2009.03.011

George, T.S., Richardson, A.E., Hadobas, P.A., Simpson, R.J., 2004. Characterization of transgenic Trifolium subterraneum $L$. which expresses phyA and releases extracellular phytase: growth and $\mathrm{P}$ nutrition in laboratory media and soil. Plant, Cell Environ. 27, 1351-1361.

George, T.S., Turner, B.L., Gregory, P.J., Cade-Menun, B.J., Richardson, A.E., 2006. Depletion of organic phosphorus from Oxisols in relation to phosphatase activities in the rhizosphere. Eur. J. Soil Sci. 57, 47-57. https://doi.org/10.1111/j.1365-2389.2006.00767.x

Gressel, N., Mccoll, J.G., Preston, C.M., Newman, R.H., Powers, R.F., 1996. Linkages between phosphorus transformations and carbon decomposition in a forest soil. Biogeochemistry 97123.

Guo, F., Yost, R.S., Hue, N.V., Evensen, C.I., Silva, J. a., 2000. Changes in Phosphorus Fractions in Soils under Intensive Plant Growth. Soil Sci. Soc. Am. J. 64, 1681. https://doi.org/10.2136/sssaj2000.6451681x

Hayes, J.. E., Richardson, A.E., Simpson, R.J., 2000. Components of organic phosphorus in soil extracts that are hydrolysed by phytase and acid phosphatase. Biol Fertil Soils 279-286.

Hedley, M.J., Stewart, J.W.B., Chauhan, B.S., 1982. Changes inorganic and organic soil phosphorus fractions induced by cultivation practices and by laboratory incubations. Soil Sci. Soc. Am. J. 46, 970-976.

Henriquez, C., 2002. Assessing soil phosphorus status under different agronomic land use. Retrospectiv Theses and Dissertations Paper 517.

Hoppe, H.G., 1983. Significance of exoenzymatic activities in the ecology of Brackish Water: measurements by means of Methylumbelliferyl-substrates. Mar. Ecol. Prog. Ser. 11, 299308.

IUSS Working Group WRB, 2015. World Reference Base for Soil Resources for 2014. World Soil Resources Report No. 106. FAO, Rome, 203 pp.

Joergensen, R.G., 1996. The fumigation-extraction method to estimate soil microbial biomass: Calibration of the kEC value. Soil Biol. Biochem. 28, 25-31. https://doi.org/10.1016/00380717(95)00102-6

Koch, O., Tscherko, D., Kandeler, E., 2007. Temperature sensitivity of microbial respiration, nitrogen mineralization, and potential soil enzyme activities in organic alpine soils. Global Biogeochem. Cycles 21, 1-11. https://doi.org/10.1029/2007GB002983

Kouno, K., Tuchiya, Y., Ando, T., 1995. Measurement of soil microbial biomass phosphorus by an anion exchange membrane method. Sbb 27, 1353-1357.

Lambers, H., Raven, J.A., Shaver, G.R., Smith, S.E., 2008. Plant nutrient-acquisition strategies change with soil age. Trends Ecol. Evol. 23, 95-103. https://doi.org/10.1016/j.tree.2007.10.008

Lambin, E.F., Meyfroidt, P., 2011. Global land use change, economic globalization, and the looming land scarcity. Proc. Natl. Acad. Sci. U. S. A. 108, 3465-72. https://doi.org/10.1073/pnas.1100480108

Lopez-hernandez, D., Brossard, M., Frossard, E., 1998. P- isotopic exchnage values in relation to Po in soils with very low P-sorbing capacities. Soil Biol. Biochem. 30, 1663-1670. 
Macklon, A.E.S., Grayston, S.J., Shand, C.A., Sim, A., Sellars, S., Ord, B.G., 1997. Uptake and transport of phosphorus by Agrostis capillaris seedlings from rapidly hydrolysed organic sources extracted from 32 P-labelled bacterial cultures. Plant Soil 163-167.

Magid, J., 1993. Vegetation effects on phosphorus fractions in set-aside soils. Plant Soil 149, 111119. https://doi.org/10.1007/BF00010768

Magid J, T.H. and C.L.M., 1996. Dynamics of organic phosphorus in soils under natural and agricultural ecosystems., in: In Humic Substances in Terrestrial Ecosystems. Elsevier, Amsterdam, pp. 429-466.

Maharjan, M., Sanaullah, M., Razavi, B.S., Kuzyakov, Y., 2017. Effect of land use and management practices on microbial biomass and enzyme activities in subtropical top-and sub-soils. Appl. Soil Ecol. 113, 22-28. https://doi.org/10.1016/j.apsoil.2017.01.008

Maranguit, D., Guillaume, T., Kuzyakov, Y., 2017. Land-use change affects phosphorus fractions in highly weathered tropical soils. Catena 149, 385-393. https://doi.org/10.1016/j.catena.2016.10.010

Matson, P.A., 1997. Agricultural Intensification and Ecosystem Properties. Science (80-. ). 277, 504509. https://doi.org/10.1126/science.277.5325.504

McGill, W.B., Cole, C. V., 1981. Comparative aspects of cycling of organic C, N, S and P through soil organic matter. Geoderma 26, 267-286. https://doi.org/10.1016/0016-7061(81)90024-0

Mganga, K.Z., Razavi, B.S., Kuzyakov, Y., 2015. Microbial and enzymes response to nutrient additions in soils of Mt. Kilimanjaro region depending on land use. Eur. J. Soil Biol. 69, 3340. https://doi.org/10.1016/j.ejsobi.2015.05.001

Motavalli, P.P., Miles, R.J., 2002. Soil phosphorus fractions after 111 years of animal manure and fertilizer applications. Biol. Fertil. Soils 36, 35-42. https://doi.org/10.1007/s00374-002-05006

Neufeldt, H., da Silva, J.E., Ayarza, M.A., Zech, W., 2000. Land-use effects on phosphorus fractions in Cerrado oxisols. Biol Fertil Soils 31, 30-37. https://doi.org/10.1007/s003740050620

O'Halloran, I.P., 1993. Effect of tillage and fertilization on inorganic and organic soil phosphorus. Can. J. Soil Sci. 73, 359-369. https://doi.org/10.4141/cjss93-038

Oberson, A., Besson, J.M., Maire, N., Sticher, H., 1996. Microbiological processes in soil organic phosphorus transformations in conventional and biological cropping systems. Biol. Fertil. Soils 21, 138-148. https://doi.org/10.1007/s003740050039

Oberson, A., Fardeau, J.C., Besson, J.M., Sticher, H., 1993. Soil phosphorus dynamics in cropping systems managed according to conventional and biological agricultural methods. Biol. Fertil. Soils 16, 111-117. https://doi.org/10.1007/BF00369411

Oberson, A., Friesen, D.K., Rao, I.M., Buhler, S., Frossard, E., 2001. Phosphorus Transformations in an Oxisol under contrasting land- use systems: The role of the soil microbial biomass. Plant Soil 237, 197-210. https://doi.org/10.1023/A:1013301716913

Paniagua, A., Mazzarino, M.J., Kass, D., Szott, L., Femandez, C., 1995. Soil phosphorus fractions under five tropical agro-ecosystems on a volcanic soil. Aust. J. Soil Res. 33, 311-320. https://doi.org/10.1071/SR9950311

Pritsch, K., Raidl, S., Marksteiner, E., Blaschke, H., Agerer, R., Schloter, M., Hartmann, A., 2004. A rapid and highly sensitive method for measuring enzyme activities in single mycorrhizal tips using 4-methylumbelliferone-labelled fluorogenic substrates in a microplate system. J. Microbiol. Methods 58, 233-41. https://doi.org/10.1016/j.mimet.2004.04.001

Razavi, B.S., Blagodatskaya, E., Kuzyakov, Y., 2015. Nonlinear temperature sensitivity of enzyme kinetics explains canceling effect-A case study on loamy haplic Luvisol. Front. Microbiol. 6, 1-13. https://doi.org/10.3389/fmicb.2015.01126

Richter, D.D., Allen, H.L., Li, J., Markewitz, D., Raikes, J., 2006. Bioavailability of slowly cycling soil phosphorus : major restructuring of soil $\mathrm{P}$ fractions over four decades in an aggrading forest. Oecologia 150, 259-271. https://doi.org/10.1007/s00442-006-0510-4 
Roldán, A., Salinas-García, J.R., Alguacil, M.M., Díaz, E., Caravaca, F., 2005. Soil enzyme activities suggest advantages of conservation tillage practices in sorghum cultivation under subtropical conditions. Geoderma $\quad 129, \quad 178-185$. https://doi.org/10.1016/j.geoderma.2004.12.042

Sarapatka, B., 2003. Phosphatase Activities (ACP, ALP) in AgroecosystemSoil. Acta Universitatis Agriculturae Sueciae, Agraria.

Schoenau, J.J., Stewart, J.W.B., Bettany, J.R., 1989. Forms and cycling of phosphorus in prairie and boreal forest soils. Biogeochemistry 8, 223-237. https://doi.org/10.1007/BF00002890

Selles, F., McConkey, B.G., Campbell, C.A., 1999. Distribution and forms of P under cultivator- and zero-tillage for continuous- and fallow-wheat cropping systems in the semi-arid Canadian prairies. Soil Tillage Res. 51, 47-59. https://doi.org/10.1016/S0167-1987(99)00027-6

Sharpley, A.N., McDowell, R.W., Kleinman, P.J. a., 2004. Amounts, Forms, and Solubility of Phosphorus in Soils Receiving Manure. Soil Sci. Soc. Am. J. 69, 1355. https://doi.org/10.2136/sssaj2005.0078le

Shih, S., Rahi, G., Ozaki, H., Smajstrla, G., 1982. Effect of water table and crops on soil temperature. Soil Crop Sci Soc FI Proc 41, 47-54.

Smeck, N.E., 1985. Phosphorus dynamics in soils and landscapes. Geoderma 36, 185-199. https://doi.org/10.1016/0016-7061(85)90001-1

Solomon, D., Lehmann, J., Mamo, T., Fritzsche, F., Zech, W., 2002. Phosphorus forms and dynamics as influenced by land use changes in the sub-humid Ethiopian highlands. Geoderma 105, 21-48. https://doi.org/10.1016/S0016-7061(01)00090-8

Spohn, M., Kuzyakov, Y., 2013. Distribution of microbial- and root-derived phosphatase activities in the rhizosphere depending on $\mathrm{P}$ availability and $\mathrm{C}$ allocation - Coupling soil zymography with $14 \mathrm{C}$ imaging. Soil Biol. Biochem. 67, 106-113. https://doi.org/10.1016/j.soilbio.2013.08.015

Stewart, J.W.B., Sharpley, A.N., 1987. Controls on dynamics of soil and fertilizer phosphorus and sulfur, in: In "Soil Fertility and Organic Matter as Critical Components of Production Systems". Soil Science Society of America and American Society of Agronomy, Madison, USA.

Stewart, J.W.B., Tiessen, H., 1987. Dynamics of soil organic phosphorus. Biogeochemistry 4, 4160.

Tiessen, H., Chacon, P., Cuevas, E., 1994. Phosphorus and nitrogen status in soils and vegetation along a toposequence of dystrophic rainforests on the upper Rio Negro. Oecologia 99, 145150. https://doi.org/10.1007/BF00317095

Tiessen, H., Moir, J.O., 1993. Characterization of available P by sequential extraction., in: Carter, M.R. (Ed. . (Ed.), Soil Sampling and Methods of Analysis. Canadian Soc. Soil Sci., pp. 7586.

Tiessen, H., Stewart, J.W.B., Cole, C.V., 1984. Pathways of phosphorus transformations in soil of differing pedogenesis. Soil Sci. Soc. Am. J 48, 853-858.

Tiessen, H., Stewart, J.W.B., Moir, J.O., 1983. Changes in organic and inorganic phosphorus composition of two grassland soils and their particle size fractions during 60-90 years of cultivation. J. Soil Sci. 34, 815-823. https://doi.org/10.1111/j.1365-2389.1983.tb01074.x

Tilman, D., Fargione, J., Wolff, B., D'Antonio, C., Dobson, A., Howarth, R., Schindler, D., Schlesinger, W.H., Simberloff, D., Swackhamer, D., 2001. Forecasting agriculturally driven global environmental change. Science 292, 281-4. https://doi.org/10.1126/science.1057544

van der Salm, C., van Middelkoop, J.C., Ehlert, P.A.I., 2017. Changes in soil phosphorus pools of grasslands following $17 \mathrm{yrs}$ of balanced application of manure and fertilizer. Soil Use Manag. 33, 2-12. https://doi.org/10.1111/sum.12333 
Vance, E.D., Brookes, P.C., Jenkinson, D.S., 1987. An extraction method for measuring soil microbial biomass C. Soil Biol. Biochem. 19, 703-707. https://doi.org/10.1016/00380717(87)90052-6

Wright, A.L., 2009. Soil phosphorus stocks and distribution in chemical fractions for long-term sugarcane, pasture, turfgrass, and forest systems in Florida. Nutr. Cycl. Agroecosystems 83, 223-231. https://doi.org/10.1007/s10705-008-9213-z

Yevdokimov, I., Blagodatskaya, E., 2014. Determination of extractable and microbial $P$ in soils with anion-exchange membranes. Goettingen, Germany.

Zamuner, E.C., Picone, L.I., Echeverria, H.E., 2008. Organic and inorganic phosphorus in Mollisol soil under different tillage practices. Soil Tillage Res. 99, 131-138. https://doi.org/10.1016/j.still.2007.12.006

Zhao, Q., Zeng, D.-H., Fan, Z.-P., Lee, D.K., 2008. Effect of Land Cover Change on Soil Phosphorus Fractions in Southeastern Horqin Sandy Land, Northern China. Pedosphere 18, $741-748$.

\subsection{Supporting Information}

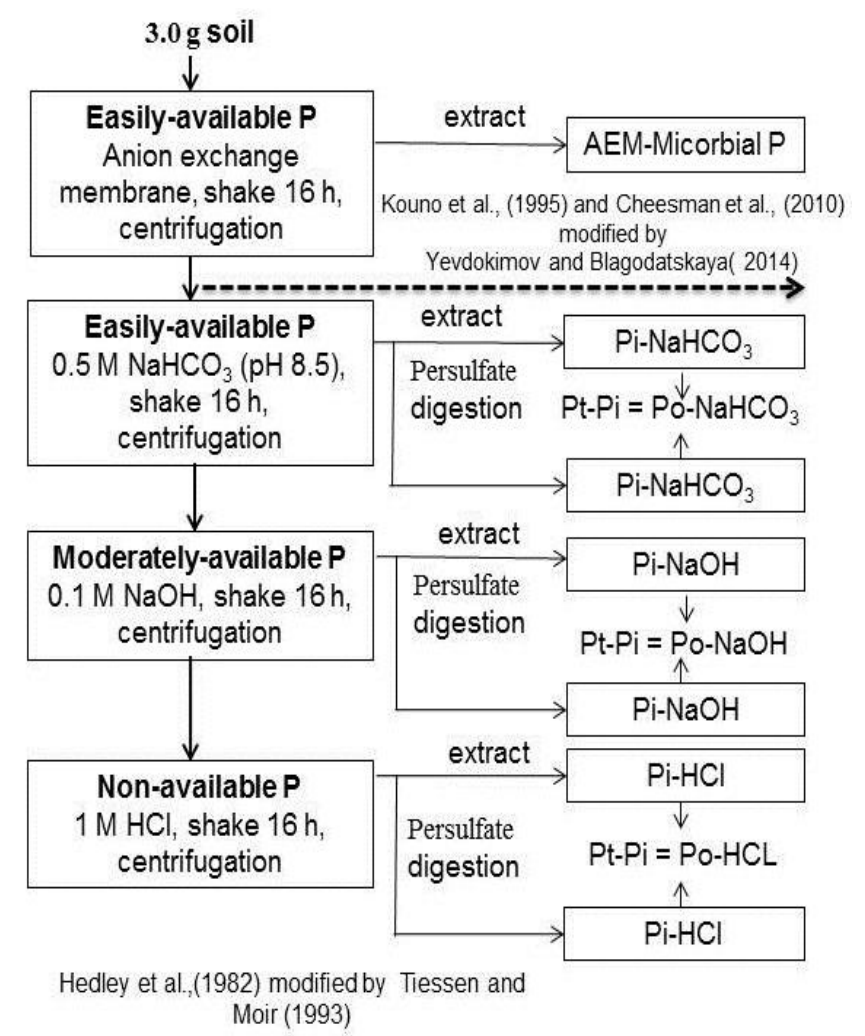

Figure S1 Sequential fractionation of phosphorus (P) in soil (Hedley et al., 1982 modified by Tiessen and Moir, 1993). The $P$ fractions were classified into three groups: 1) easily-available $P$ included NaHCO3-extractable $\mathrm{P}$ and microbial $\mathrm{P}$; 2) moderately-available $\mathrm{P}$ included $\mathrm{P}$ extracted from $0.5 \mathrm{M}$ $\mathrm{NaOH}$ and 3) non-available $\mathrm{P}$ included $\mathrm{P}$ extracted by $1 \mathrm{M} \mathrm{HCl}$ (Tiessen et al., 1984). Dashed line (-) shows microbial biomass $P$ was measured based on the method of Kouno et al., (1995) and Cheesman et al., (2010) slightly modified by Yevdokimov and Blagodatskaya (2014). 


\title{
3.3 Study 3: Nutrient availability regulates soil organic matter decomposition depending on land use
}

\author{
Menuka Maharian ${ }^{1,2,{ }^{*}}$, Huadong Zang ${ }^{3}$, Evgenia Blagodatskaya ${ }^{1,4}$, Yakov Kuzyakov $^{1,3}$ \\ Status: In preparation \\ ${ }^{1}$ Department of Soil Science of Temperate Ecosystems, University of Göttingen, Göttingen, Germany \\ ${ }^{2}$ Institute of Forestry, Tribhuwan University, Hetauda, Makwanpur, Nepal \\ ${ }^{3}$ Departments of Agricultural Soil Science, University of Göttingen, Göttingen, Germany \\ ${ }^{4}$ Institutes of Physicochemical and Biological Problems in Soil Science, Pushchino, Russia
}

\subsubsection{Abstract}

Variations in land use systems and nutrient input (nitrogen $(\mathrm{N})$ and phosphorous $(\mathrm{P})$ ) strongly affect carbon (C) dynamics and storage in soil. However, a mechanistic understanding of the effects of labile $C$ and fertilizer input on soil organic matter decomposition among land use systems remains incomplete, especially in tropics areas. ${ }^{14} \mathrm{C}$ labeled glucose and nutrients were added to soils $(0-20 \mathrm{~cm})$ from organic farming, conventional farming, and forest. ${ }^{14} \mathrm{CO}_{2}$ and total $\mathrm{CO}_{2}$ emissions were measured continuously over 45 incubation days and microbial biomass was measured at the experiment's conclusion. Increased soil organic matter (SOM) decomposition was accompanied by decreasing microbial biomass with $\mathrm{C}$ addition in organic soil, pointing to microbial-necromass as the source of priming. Addition of $\mathrm{N}$ with $\mathrm{C}$ strongly suppressed SOM decomposition in conventional and forest soil, providing support for the preferential microbial substrate utilization mechanism. While addition of $\mathrm{P}$ with $\mathrm{C}$ accelerated decomposition of SOM in three land use type due to microbial mining of limiting nutrients (i.e. $\mathrm{N}$ ). The interaction of $\mathrm{N}$ and $\mathrm{P}$ fertilization when combined with $\mathrm{C}$ has contrasting effects on the decomposition process. $\mathrm{N}$ and $\mathrm{P}$ fertilization promotes the decomposition process in organic soils, supporting the theory of stoichiometric decomposition. However, $\mathrm{P}$ fertilization suppressed the decomposition process in N-limited conventional and forest soils, indicating that SOM decomposition in more responsive to $\mathrm{N}$ addition than $\mathrm{P}$. In Conclusion, SOM dynamics are regulated by the availability of essential nutrients ( $N$ and $P$ ) under different land use systems. Thus, $\mathrm{N}$ and $\mathrm{P}$ availability should be considered when analyzing $\mathrm{C}$ dynamics and sequestration in tropic ecosystems. 
Keywords: Land use; nutrients; soil organic matter decomposition; microbial-necromass

Corresponding Author: Menuka Maharjan, menuka48maharjangmail.com

\subsubsection{Introduction}

Land-use change is one of the most important factors affecting soil organic carbon (SOC) dynamics (Van Noordwijk et al., 1997; Don et al., 2011; Guillaume et al., 2015). Global carbon loss due to land-use change was about 48-114 Pg C prior to 1850 (Houghton, 2012). This figure increased dramatically in the last 150 years, with losses of $108-188 \mathrm{Pg}$ C during the period of 1850-2005. While these losses mostly originate from biomass removal, $25 \%$ resulted from accelerated soil organic matter (SOM) decomposition due to land-use change (Houghton, 2012; Lal, 2004). Therefore, loss of SOC is a well-known consequence of land-use change, especially in conversions of natural ecosystems to agricultural land (van Noordwijk et al., 1997; Houghton, 2012).

The effect of land use on soil $C$ content is mainly the result of fertilizer application (Townsend et al., 1996; Christensen and Johnston, 1997; Nadelhoffer et al., 1999), crop residue management practices (Shahbaz et al., 2015), conversion tillage and conversion of cropland to grassland (Smith et al., 2000; Six et al., 2002; West and Post, 2002). Fertilizer application is the most common anthropogenic practice to increase plant productivity for sustaining the growing population (MA, 2005). However, the effects of changes in management practices have not been thoroughly considered in estimations of global $\mathrm{C}$ loss (Kutsch et al., 2010).

It has long been recognized that nutrient limitation restricts microbial respiration, however, it is challenging to predict which nutrients regulate respiratory activity in specific ecosystems (Reed et al., 2011; Fisk et al., 2015). Globally, $\mathrm{N}$ is considered as one of the most limiting nutrients for plant growth, significantly affecting plant productivity in most natural ecosystems (Bobbink et al., 2010). Hence, prior studies have focused on the potential role of $\mathrm{N}$ enrichment on $\mathrm{CO}_{2}$ emissions and $\mathrm{SOC}$ dynamics in different land use systems (Cleveland and Townsend, 2006; Waldrop and Zak, 2006; Janssens et al., 2010; Liu and Greaver, 2010). These studies have reached divergent conclusions, showing positive negative or no effect of $\mathrm{N}$ addition on SOM decomposition. In nutrient limited soil, $\mathrm{N}$ addition stimulates microorganisms to mine for nutrients from native SOM (Poeplau et al., 2016) (Zang et al 2017), enhancing decomposition of SOM, i.e., a positive priming effect (PE). However, in nutrient-rich soil, microorganisms will utilize added $\mathrm{N}$ instead of decomposing native SOM (Dijkstra et al., 2013; Cheng et al., 2014), reducing the 
decomposition of SOM, i.e., a negative PE. These two mechanisms are referred to as SOM mining and preferential microbial substrate utilization, respectively (Dijkstra et al., 2013; Cheng and Kuzyakov, 2005). Importantly, it is challenging to predict ecosystem responses to $\mathrm{N}$ fertilization (Poeplau et al., 2016) in contrasting soil types. However, the diverse responses recorded in previous $\mathrm{N}$ fertilization studies indicate that the effect of $\mathrm{N}$ on SOC dynamics might depend on presence or absence of other nutrients in soils (Townsend et al., 2011) under varying environmental conditions. This calls for further analysis of the relationship between SOM decomposition and $\mathrm{N}$ fertilization (Chen et al., 2007) under different land use systems with diverse nutrients contents. Other than N,P is another limiting nutrient in soil across different ecosystems. The effect of $P$ addition on SOC dynamics are not well studied (Poeplau et al., 2016). However, evidence from prior studies demonstrated that $\mathrm{P}$ addition significantly increases soil $\mathrm{CO}_{2}$ respiration leading to $\mathrm{C}$ losses, mostly in forest soils (Cleveland et al., 2002; Cleveland and Townsend, 2006; Fisk et al., 2015). This calls for further analysis for $P$ addition on soil $C$ sequestration under contrasting land use systems.

While prior studies have investigated the effects of nutrient availability on SOM decomposition, most analyses were limited to single nutrients $(\mathrm{N}$ or $\mathrm{P})$. Not surprisingly, the potential effects of multiple-nutrient additions ( $N$ in conjunction with $P$ ) on SOM decomposition have rarely been addressed under different land use systems (Fornara et al., 2013). Furthermore, the analysis of $C$ sequestration remains incomplete without consideration of the effect of multiple nutrient additions on the decomposition process. Thus, understanding the interaction between single vs. multiple nutrient availability and $C$ sequestration in soil deserves attention, and is essential to accurately predict the fate of soil $\mathrm{C}$ under changing nutrient regimes in response to environmental change (Paterson et al., 2009; Reed et al., 2011; Fisk et al., 2015).

Thus, this study was motivated by the need to understand the mechanism of priming effects in response to single vs multiple nutrient additions under different land use systems, i.e., organic farming, conventional farming, and forest. We hypothesized that i) $\mathrm{C}$ addition with $\mathrm{N}$ addition suppresses decomposition of SOM ii) $\mathrm{C}$ with $\mathrm{P}$ addition accelerates emission of $\mathrm{CO}_{2}$ across land use systems, and iii) multiple nutrient $(\mathrm{N}+\mathrm{P})$ addition with $\mathrm{C}$ increases decomposition of SOM across land use systems. To test these hypotheses, we conducted a laboratory incubation experiment using soils from three land use systems with addition of labile $\mathrm{C}$ and other nutrients $(\mathrm{N}, \mathrm{P})$. We added nutrients both individually ( $\mathrm{N}$ or $\mathrm{P}$ ) and in combination, which allowed us to examine the effects of these different nutrient inputs on $\mathrm{CO}_{2}$ emissions and the soil priming effect. 


\subsubsection{Materials and Methods}

\subsubsection{Site description and soil sampling}

Soil samples were collected from three land use systems (organic farming, conventional farming, and forest) in the Chitwan district $\left(27^{\circ} 35^{\prime} \mathrm{N} 84^{\circ} 30^{\prime} \mathrm{E}\right)$ of Nepal. The climate of this area is subtropical, with an average temperature of $30^{\circ} \mathrm{C}$ and annual rainfall of $1763 \mathrm{~mm}$. The texture of the soil is sandy loam.

The organic farm has been under organic management for 15 years. The crop rotation is maize+rice+vegetables/mustard in organic farming and maize+rice+wheat/lentils in conventional farming. About 10 ton ha $\mathrm{hr}^{-1}$ of farmyard manure and vermicomposting are applied in organic farming, whereas urea $\left(60 \mathrm{~kg} \mathrm{ha}^{-1} \mathrm{yr}^{-1}\right)$ and potassium $\left(15 \mathrm{~kg} \mathrm{ha}^{-1} \mathrm{yr}^{-1}\right)$ are added in conventional farming. Forest is dominated by Shorea robusta, commonly known as Sal. Pesticides are applied only in conventional farming. Detailed descriptions of the study sites are provided in (Menuka Maharjan et al., 2017).

Soil samples were collected from the upper $0-20 \mathrm{~cm}$ from four random sampling locations in each land use system. Fine roots, plant remnants, and debris were carefully removed using tweezers. The samples were kept cold $\left(\sim 4{ }^{\circ} \mathrm{C}\right)$ prior to analysis. The soils are classified as Gleyic Cambisols for the organic farm and forest, and Eutric Cambisol for the conventional farm (IUSS Working Group WRB, 2015). The chemical properties of the soils under different land-use system are presented in Table 1.

Table 1 Description of chemical properties of soil under different land use systems

\begin{tabular}{lcccc}
\hline Land use & Total $\mathbf{C}(\%)$ & Total $\mathbf{N}(\%)$ & Total $\mathbf{P}\left(\mathbf{m g ~ P ~ k g} \mathbf{~}^{-1} \mathbf{s o i l}\right)$ & $\mathbf{p H}\left(\mathbf{H}_{\mathbf{2}} \mathbf{O}\right)$ \\
\hline $\begin{array}{l}\text { Organic farming }= \\
15 \text { years }\end{array}$ & 1.7 & 0.16 & 332.2 & 7.5 \\
$\begin{array}{l}\text { Conventional } \\
\text { farming }\end{array}$ & 1.3 & 0.11 & 130.0 & 5.0 \\
Forest & 0.7 & 0.06 & 89.4 & 5.5 \\
\hline
\end{tabular}




\subsubsection{Experimental design}

$22 \mathrm{~g}$ (oven-dried weight) of soil from each land use system was weighed into a $100-\mathrm{ml}$ jar. The soil was adjusted to $50 \%$ of the water holding capacity (WHC) and pre-incubated for 15 days at $22^{\circ} \mathrm{C}$. After pre-incubation, $\mathrm{N}$ as $\mathrm{KNO}_{3}\left(200 \mathrm{~kg} \mathrm{ha}{ }^{-1}\right)$ and $\mathrm{P}$ as $\mathrm{KH}_{2} \mathrm{PO}_{4}(120 \mathrm{~kg}$ $\mathrm{ha}^{-1}$ ) was added to the soils, except for control and only glucose addition treatments. After 15 days of nutrient addition, soil was amended with either distilled water (control treatment) or with glucose (other treatments). Uniformly-labeled ${ }^{14} \mathrm{C}$ glucose was added at a rate of $239 \mu \mathrm{g} \mathrm{C} \mathrm{g}^{-1}$ soil (final activity of $7514 \mathrm{DPM} \mathrm{g}^{-1}$ soil), $184 \mu \mathrm{g} \mathrm{C} \mathrm{g}^{-1}$ soil (final activity of 7401 DPM g${ }^{-1}$ soil) and $132 \mu \mathrm{g} \mathrm{g} \mathrm{g}^{-1}$ soil (final activity of $7485 \mathrm{DPM} \mathrm{g}^{-1}$ soil ) in organic farming, conventional farming and forest, respectively. The amount of glucose addition was equivalent to $30 \%$ of initial microbial biomass carbon (MBC) in the three land use systems. Glucose was applied to soil as a solution to reach the optimal soil moisture content of $70 \%$ of WHC. Each treatment had four replicates in respective land use system for each sampling date. In total, there were five treatments in each land use system: 1) Control (water only, Ctl), 2) Glucose only (C), 3) Glucose +Nitrogen $(\mathrm{C}+\mathrm{N})$, 4) Glucose + Phosphorus $(\mathrm{C}+\mathrm{P})$, and 5) Glucose+ Nitrogen+ Phosphorus $(\mathrm{C}+\mathrm{N}+\mathrm{P})$.

\subsubsection{Incubation and sampling}

After adding distilled water or glucose solution to the soil, small vials with $3 \mathrm{ml}$ of $1 \mathrm{M} \mathrm{NaOH}$ were placed in the incubation vessels to trap $\mathrm{CO}_{2}$. The vessels were immediately sealed and incubated for 45 days at $22^{\circ} \mathrm{C}$, with moisture maintained at $70 \%$ WHC throughout the incubation period. The vials containing $\mathrm{NaOH}$ were removed and replaced by new vials at $1,3,5,7,11,14,21,28,35$ and 45 days. $\mathrm{CO}_{2}$ trapped in $\mathrm{NaOH}$ solution was precipitated with $0.5 \mathrm{M} \mathrm{BaCl}_{2}$ solution. The total amount of $\mathrm{CO}_{2}$ trapped in the vials was measured by titration of $0.25 \mathrm{ml}$ of $\mathrm{NaOH}$ solution with $0.025 \mathrm{M} \mathrm{HCl}$ using phenolphthalein as an indicator. For ${ }^{14} \mathrm{C}$ activity measurement, $1 \mathrm{ml}$ of ${ }^{14} \mathrm{CO}_{2}$ enriched $\mathrm{NaOH}$ from the $\mathrm{CO}_{2}$ traps was mixed with $3 \mathrm{ml}$ of the scintillation cocktail Rotiszint EcoPlus (Carl Roth Company, Germany) and measured using a Hidex 300 SL Automatic TDCR Liquid Scintillation Counter (Beckman Coulter Inc., USA). Prior to measurements, samples were properly mixed and homogenized for $10 \mathrm{~s}$ using a Vortex genie 2 (Scientific Industries INC, USA), and kept overnight. The ${ }^{14} \mathrm{C}$ counting efficiency and the ${ }^{14} \mathrm{C}$ activity measurement error were around $80 \%$ and $2 \%$ respectively. 


\subsubsection{Microbial biomass}

Microbial biomass $\mathrm{C}$ was measured at the end of the incubation period and determined by the chloroform fumigation method (Vance et al., 1987). Briefly, $8 \mathrm{~g}$ of soil was divided in two subsamples. One subsample (about $4 \mathrm{~g}$ ) was fumigated with chloroform for $24 \mathrm{~h}$. Both subsamples were shaken for $1 \mathrm{~h}$ with $20 \mathrm{ml}$ of $0.05 \mathrm{M} \mathrm{K}_{2} \mathrm{SO}_{4}$. The obtained extracts were analyzed for the total C concentration using a 2100 TOC/TIC analyzer (Analytik Jena, Germany). The extracts of the non-fumigated subsamples were used to measure dissolved organic carbon (DOC). The total amount of extractable MBC was calculated based on the difference of $\mathrm{K}_{2} \mathrm{SO}_{4}$-extracable $\mathrm{C}$ between fumigated and non-fumigated subsamples using a $\mathrm{k}_{\mathrm{EC}}$ factor of 0.45 (Joergensen, 1996). The ${ }^{14} \mathrm{C}$ activity both in fumigated and nonfumigated extracts was measured in $5 \mathrm{ml}$ aliquots added to $15 \mathrm{ml}$ of scintillation cocktail. The ${ }^{14} \mathrm{C}$ activity in microbial biomass was calculated by taking the difference of the activities from fumigated and non-fumigated samples.

\subsubsection{Calculation and statistical analysis}

The amount of glucose-derived $\mathrm{C}\left(\mathrm{C}_{\mathrm{G} \text {-derived }}\right)$ was calculated based on the current ${ }^{14} \mathrm{C}$ radioactivity $\left({ }^{14} \mathrm{C}\right.$ curr $)$, the amount of added glucose $\left({ }^{14} \mathrm{C}_{\mathrm{G}}\right)$, and the initial radioactivity of the added glucose $\left({ }^{14} \mathrm{C}_{\text {inital }}\right)$ in each land use-system:

$\mathrm{C}_{\mathrm{G} \text {-derived }}={ }^{14} \mathrm{C}_{\text {curr }}{ }^{*} \mathrm{C}_{\mathrm{G}} /{ }^{14} \mathrm{C}_{\text {initial }}$

Then, SOM-derived $\mathrm{C}$ was calculated by following equation:

$\mathrm{C}_{\text {SOM-derived }}=\mathrm{C}_{\text {total }}-\mathrm{C}_{\mathrm{G} \text {-derived }}$

where $\mathrm{C}$ total is the total amount of $\mathrm{C}$ in the corresponding pool $\left(\mathrm{CO}_{2}\right.$, $\mathrm{DOC}$, microbial biomass).

At the final, priming effects (PE) were calculated by using following equation:

$\mathrm{PE}=\left[\mathrm{CO}_{2}\right]_{\text {total- }}\left[\mathrm{CO}_{2}\right]_{\mathrm{G}}-\left[\mathrm{CO}_{2}\right]_{\text {control }}$

where $\left[\mathrm{CO}_{2}\right]_{\text {total }},\left[\mathrm{CO}_{2}\right]_{\mathrm{G}}$ and $\left[\mathrm{CO}_{2}\right]_{\text {control }}$ represent $\mathrm{CO}_{2}$ emissions from soil after nutrients treatment, only glucose treatment and without any amendment, respectively.

The effect of nutrients amendment on $\mathrm{CO}_{2}$ rate, cumulative $\mathrm{CO}_{2}$, priming effect, and $\mathrm{MBC}$ in different land-use system were analyzed using one-way analysis of variance (ANOVA) at a significance level of $p<0.05$ using the statistical software Statistica 12. 


\subsubsection{Results}

\subsubsection{Cumulative $\mathrm{CO}_{2}$ and priming effects}

Initially, $\mathrm{C}$ and nutrient addition resulted in high $\mathrm{CO}_{2}$ emission rates, which sharply decreased within $24 \mathrm{~h}$ across all three land use system and recovered after 2 weeks of incubation (Fig.1). $\mathrm{C}$ addition increased $\mathrm{SOM}$-derived $\mathrm{CO}_{2}$ emissions, causing positive $\mathrm{PE}$ (37 $\mu \mathrm{g} \mathrm{C} \mathrm{g}^{-1}$ ) in soil under organic farming over 45 days (Fig. 3a). In other soils, however, the PE was much lower. For example, slightly positive PEs were observed 45 days after $\mathrm{C}$ addition in soil under conventional farming $\left(1 \mu \mathrm{g} \mathrm{C} \mathrm{g}^{-1}\right)$ and forest $\left(6 \mu \mathrm{g} \mathrm{C} \mathrm{g} \mathrm{g}{ }^{-1}\right)$, respectively (Fig. 3b, 3c). There was a strong interaction of added glucose and mineral $\mathrm{N}$ in all land use systems. SOM-derived $\mathrm{CO}_{2}$ in $\mathrm{C}+\mathrm{N}$ treatments were significantly higher than for $\mathrm{C}$-only treatments in soil under conventional farming and forest, causing strong negative PEs of 33 and $52 \mu \mathrm{g} \mathrm{g} \mathrm{g}^{-1}$, respectively. However, SOM-derived $\mathrm{CO}_{2}$ was not significantly different in $\mathrm{C}+\mathrm{N}$ and $\mathrm{C}$ treatments under organic fertilization. Application of $\mathrm{P}$ in addition to C stimulated the PE by $52-946 \%$ (Fig. 3). Interestingly, the addition of $C$ and $N$ in conjunction with $\mathrm{P}$ showed contrasting effects on SOM decomposition i.e. positive priming in soil under organic farming $\left(66 \mu \mathrm{g} \mathrm{g} \mathrm{g}^{-1}\right)$ and negative priming in conventional farming (35 $\mu \mathrm{g} \mathrm{C} \mathrm{g} \mathrm{g}^{-1}$ ) and forest (13 $\mu \mathrm{g} \mathrm{g} \mathrm{g}^{-1}$ ) (Fig. 3). Cumulative ${ }^{14} \mathrm{CO}_{2}$ emissions were higher after $\mathrm{C}_{+} \mathrm{P}$ additions compared to other treatments in soil under organic farming. In soil under conventional farming and forest, the emission of cumulative ${ }^{14} \mathrm{CO}_{2}$ was similar among treatments (Fig.S1).

Overall, $\mathrm{P}$ addition accelerated decomposition of SOM in all land use systems, while N addition suppressed SOM decomposition under conventional farming and forest. Addition of $\mathrm{N}$ in conjunction with $\mathrm{P}$ promoted the decomposition process in soil under organic farming, while suppressing decomposition under conventional farming and forest (Fig.2). 


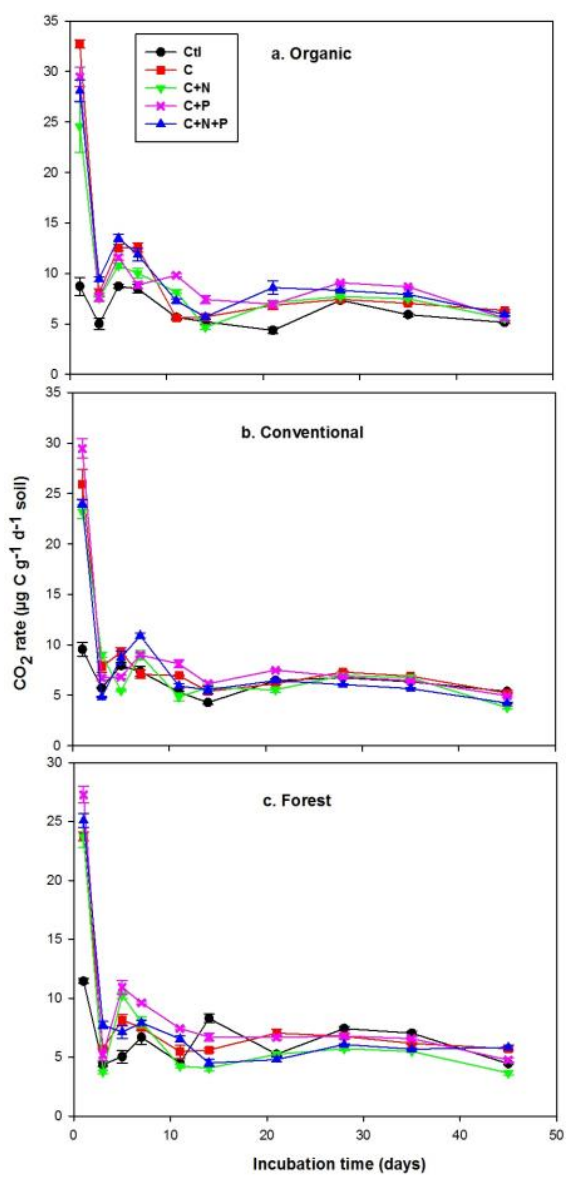

Figure 1 Rate of $\mathrm{CO}_{2}$ emission in soil under organic farming (a), conventional farming (b), and forest (c). Control, $\mathrm{C}, \mathrm{C}+\mathrm{N}, \mathrm{C}+\mathrm{P}$, and $\mathrm{C}+\mathrm{N}+\mathrm{P}$ in the figure represent the addition of water, glucose only, glucose + nitrogen, glucose + phosphorus, glucose + nitrogen + phosphorus, respectively. Values are means \pm standard error $(n=4)$.

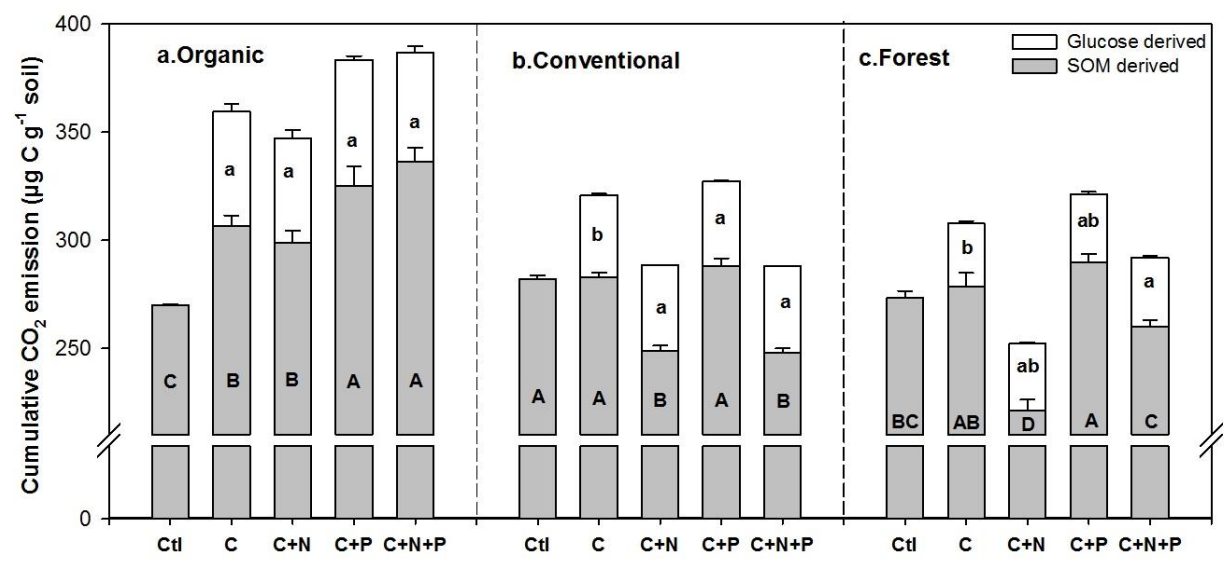

Figure 2 Cumulative $\mathrm{CO}_{2}$ derived from soil organic matter (blue) and from added glucose (blank) in soil under organic farming (a), conventional farming (b), and forest (c) at the end of incubation. Control, $\mathrm{C}, \mathrm{C}+\mathrm{N}, \mathrm{C}+\mathrm{P}$, and $\mathrm{C}+\mathrm{N}+\mathrm{P}$ in the figure represent the addition of water, glucose only, glucose + nitrogen, glucose + phosphorus, glucose + nitrogen + phosphorus, respectively. Values are means \pm standard error $(n=4)$. Capital letters indicate the significance difference among treatments for SOM derived cumulative $\mathrm{CO}_{2}$ emission. Small letters indicate the significance difference among treatments for Glucose derived cumulative $\mathrm{CO}_{2}$ emission. 


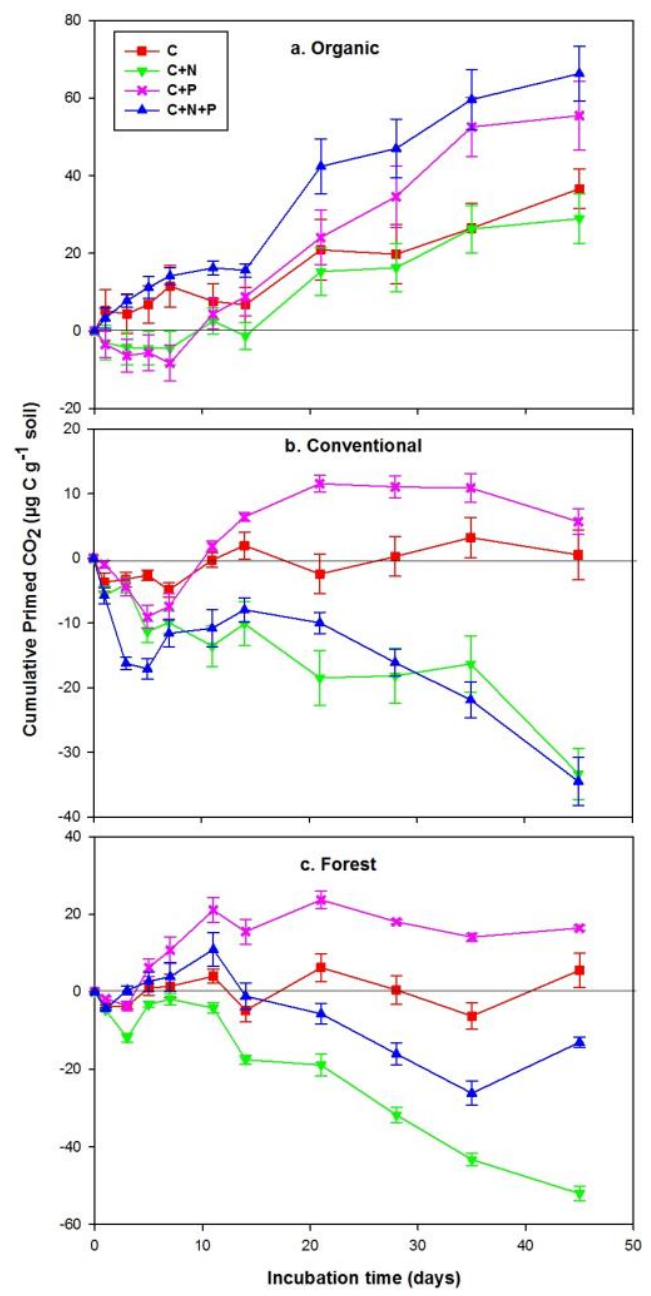

Figure 3 Cumulative primed $\mathrm{CO}_{2}$ emission in soil under organic farming (a), conventional and farming (b) and forest (c). $\mathrm{C}, \mathrm{C}+\mathrm{N}, \mathrm{C}+\mathrm{P}$, and $\mathrm{C}+\mathrm{N}+\mathrm{P}$ in the figure represent the addition of glucose only, glucose + nitrogen, glucose + phosphorus, glucose + nitrogen + phosphorus, respectively. Values are means \pm standard error $(n=4)$.

\subsubsection{Microbial biomass}

$\mathrm{C}$ addition alone and $\mathrm{C}$ addition with $\mathrm{N}$ significantly decreased SOM-derived microbial biomass by 68 and $90 \mu \mathrm{g} \mathrm{C} \mathrm{g}^{-1}$, respectively, in organic soil after 45 days incubation (Fig. 4a). In contrast, SOM-derived microbial biomass increased after addition of $C$ with $P$ (by $12 \%$ ) and N+P (by 18\%) in organic soil (Fig.4a). SOM-derived microbial biomass increased by $22 \%$ after $C$ and $P$ addition in conventional soil (Fig. 4b), whereas no effect was found for other treatments. There was no significant effect of $\mathrm{C}$ addition alone and in conjunction with nutrients on SOM-derived microbial biomass in forest soil (Fig. 4c). The incorporation of ${ }^{14} \mathrm{C}$ was higher in organic soil (up to $24 \mu \mathrm{g} \mathrm{C} \mathrm{g}$ ) and conventional soil (up to $21 \mu \mathrm{g} \mathrm{C} \mathrm{g}{ }^{-1}$ ) than in forest soil ( up to $9 \mu \mathrm{C} \mathrm{g}^{-1}$ ), but did not differ significantly between treatments in each land use type (Fig.4a, 4b, 4c). 


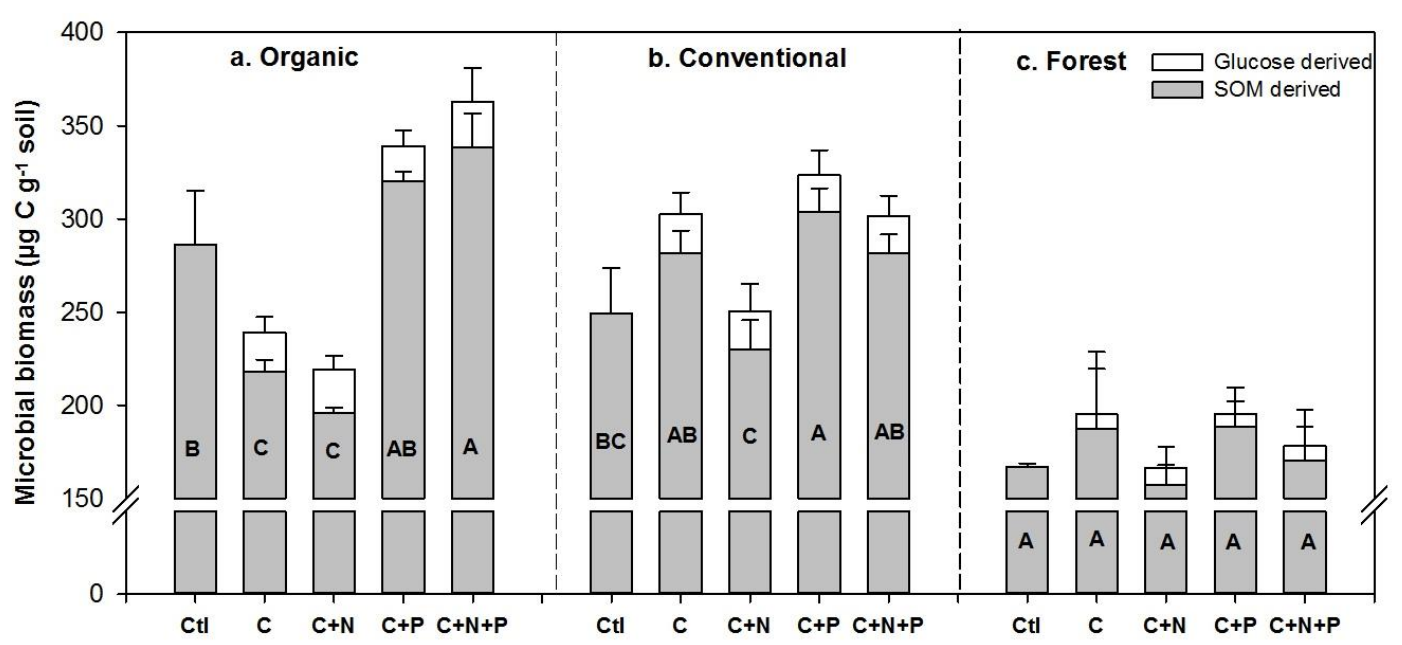

Figure 4 Microbial biomass derived from soil organic matter and from added glucose in soil under organic farming (a), conventional farming, (b) and forest (c) at the end of incubation. Control, C, $\mathrm{C}+\mathrm{N}, \mathrm{C}+\mathrm{P}$, and $\mathrm{C}+\mathrm{N}+\mathrm{P}$ in the figure represent the addition of water, glucose only, glucose + nitrogen, glucose + phosphorus, glucose + nitrogen + phosphorus, respectively. Values are means \pm standard error $(n=4)$.

\subsubsection{Discussion}

Varying microbial respiratory responses to the addition of single vs multiple nutrients in individual land use types (Fig.2) requires the mechanistic understanding of various sequestration responses under different nutrient availabilities ( $N$ vs $P$ vs $N+P$ ). Specifically, $\mathrm{C}$ addition increased cumulative $\mathrm{CO}_{2}$ emission (by 33\%) but decreased microbial biomass (by $16 \%$ ) in soil under farming (Fig. 2a, 4a.). This is contrary to our general assumption of increased $\mathrm{CO}_{2}$ emissions linked to increases in microbial biomass. Moreover, the amount of the primed $\mathrm{CO}_{2}$ emission ( $37 \mu \mathrm{g} \mathrm{C} \mathrm{g}^{-1}$ ) was comparable to decreased microbial biomass (i.e. $47 \mu \mathrm{g} \mathrm{g} \mathrm{g}^{-1}$ ) (Fig.3a and 4a). Similarly studies have demonstrated an increase in SOMderived $\mathrm{CO}_{2}$ despite reductions in microbial biomass of up to $60 \%$ following addition of plant residue (Shahbaz et al., 2017). This reflects the primed $\mathrm{CO}_{2}$ arises from reutilization of microbial necromass (produced after a strong decrease in microbial biomass), indicating that necromass serves as an SOM primer (Miltner et al., 2009; Miltner et al., 2012; Shahbaz et al., 2017). Thus, our results provide further support for increases in microbialnecromass as a new mechanism of PE induction. Labile $C$ addition stimulates microbial activity, which can be verified by the fast mineralization of ${ }^{14} \mathrm{C}$-glucose in the beginning of incubation (Fig. S1). More than half of the added ${ }^{14} \mathrm{C}$-glucose was already mineralized to $\mathrm{CO}_{2}$ after 20 days. Thus, the stimulated microorganisms start to decompose SOM to fulfill metabolic requirements (Blagodatskaya and Kuzyakov, 2008; Mason-Jones and Kuzyakov, 2017 ) in the organic treatment. However, microorganisms may utilize added labile $C$ for maintaining their population, as no energy was present for decomposing SOM due to 
strong limitation of nutrients ( $\mathrm{N}$ and $\mathrm{P}$ ) in soil under conventional and forest. This is evidenced by the stability of microbial biomass after $C$ addition (Fig. 4 b, 4c), demonstrating negligible PE (Fig. 3b, 3c).

In contrast to $\mathrm{C}$ addition, $\mathrm{C}$ with $\mathrm{N}$ addition caused a strong negative $\mathrm{PE}$ in soil under conventional farming and forest (Fig.3). Microbial respiration following $\mathrm{N}$ addition depends on $\mathrm{N}$ availability and total $\mathrm{N}$ content in soil, and is therefore a good marker of $\mathrm{N}$ availability in land use systems (Poeplau et al., 2016). The content of $N$ and $P$ was much lower (Table 1 ) in conventional and forest soil, implying a higher limitation of nutrients ( $N$ and $P$ ) than in soil under organic farming. In nutrient limited soil, i.e., conventional farming and forest, microorganisms prefer to utilize added $\mathrm{N}$ instead of decomposing SOM for fulfilling $\mathrm{N}$ requirements, alleviated N-mining (Moorhead and Sinsabaugh, 2006; Craine et al., 2007; Poeplau et al., 2016). This is referred to as preferential microbial substrate utilization (Kuzyakov, 2002). However, short-term negative priming at the beginning and positive PE at the end of incubation was observed with $\mathrm{C}$ and $\mathrm{N}$ addition in soil under organic farming (Fig.3a). Added $\mathrm{C}$ and $\mathrm{N}$ is limited after long-term incubation, which is demonstrated by the fast utilization of ${ }^{14} \mathrm{C}$-glucose at the beginning of organic treatment (Fig S1). These energy and nutrient limitations may promote the transitions of microorganism from the active to dormant state, which was evident from a decrease in microbial biomass (by $23 \%$ ) in the soil under organic farming (Fig. 4a). These results again reflect the reutilization of microbial necromass as primed $\mathrm{CO}_{2}$ (Miltner et al., 2009; Miltner et al., 2012), contributing to the decomposition of SOM to fulfill nutrient demands for the remaining microorganisms (Shahbaz et al., 2017). Thus, our first hypothesis that $\mathrm{N}$ addition suppresses the decomposition of SOM was confirmed in soil under conventional and forest.

In contrast to the suppressive effects of $\mathrm{N}, \mathrm{P}$ addition in combination with $\mathrm{C}$ enhanced (up to $42 \%$ ) microbial respiration across all land use type (Fig 2). A lower C:P ratio of the DOM fraction as a result of $\mathrm{P}$ addition could lead to faster decomposition of SOM by the $\mathrm{P}$-limited soil microbial community (Cleveland et al., 2006). In our study, addition of C+P compared to $C$ alone increased microbial biomass up to $42 \%$ (Fig.4). These results indicate that $P$ addition may activate microorganisms, increasing their demand for $N$. Thus, microorganisms likely increased SOM mining to meet this increased demand for $\mathrm{N}$ (Moorhead and Sinsabaugh, 2006; Meyer et al., 2017). Hence, our second hypothesis, which predicted that $\mathrm{C}$ with $\mathrm{P}$ addition would accelerate $\mathrm{CO}_{2}$ emissions, was confirmed by the increased $\mathrm{CO}_{2}$ emission in soil for land use systems. 
Similar to $\mathrm{N}$ addition, $\mathrm{C}$ with multiple nutrient $(\mathrm{N}+\mathrm{P})$ addition strongly suppressed the decomposition of SOM in soil under conventional farming and forest (Fig.2b, 2c). The content of $\mathrm{N}$ and $\mathrm{P}$ was much lower (Table 1), implying greater $\mathrm{N}$ and $\mathrm{P}$ limitations in conventional and forest soil than in soil under organic farming. This is supported by the faster mineralization of added glucose after nutrient addition relative to C-only additions (Fig. S1). Furthermore, PE responded more to $\mathrm{N}$ than to $\mathrm{P}$ in soil under conventional farming and forest after addition of multiple nutrients. The potential explanation that the decrease in respiration resulted from a reduction in microbial biomass after $\mathrm{N}$ addition (Ramirez et al., 2012; Janssens et al., 2010; Liu and Greaver, 2010) is not valid in our study, where microbial biomass was stable following addition of $N$ and $N+P$. Active microbial biomass, instead of total microbial biomass, contributes to soil respiration (Salazar-Villegas et al., 2016), and should thus be the focus when analyzing decomposition processes. Additionally, $\mathrm{N}$ addition alters the microbial community structure by increasing the growth of bacterial-grazing protozoans (Clarholm, 1985; Blagodatskaya et al., 2014). Therefore, we assume that active microbial biomass could decrease while total microbial biomass remained stable in these land use types. Furthermore, protozoans might modify the bacterial community structure after $\mathrm{N}$ addition, decelerating the decomposition process in conventional and forest soil. Notably, it implies that $\mathrm{N}$ availability could play a crucial role in microbial community structure.

However, soil under organic treatment showed a strong positive PE after addition of multiple nutrients (Fig. 3a), which could be attributed to increased microbial biomass (by 18\%) (Fig.4a). SOM decomposition has the tendency to be faster in nutrient-rich than in nutrient-limited soil (Torn et al., 2005), further suggesting that increased nutrient availability could result in stronger soil respiration. Organic soil receives farmyard manure, leading to high organic $\mathrm{C}$, total $\mathrm{N}$ (Maharjan et al., 2017) and total $\mathrm{P}$ (Table 1). Further additional nutrients stimulate microorganisms and enhance SOM decomposition to fulfill the enhanced microbial metabolic requirements, supporting the theory of stoichiometric decomposition (Hessen et al., 2004; Chen et al., 2014) in the soil under organic farming. Overall, the results of multiple nutrients addition showed that the effect of $\mathrm{N}$ addition was more pronounced than for $\mathrm{P}$ addition in conventional and forest soils. Our third hypothesis, that $\mathrm{C}$ addition with multiple nutrients increases decomposition of SOM across land use systems, was supported for soil under organic farming but rejected for soil under conventional farming and forest. 


\subsubsection{Conclusions}

Our findings highlight the various mechanisms involved in SOM decomposition under single vs multiple nutrients availability with organic, conventional and forest soil. $\mathrm{C}$ addition accelerated SOM decomposition, while no incorporation of SOM-derived C into microbial biomass was detected in organic soil. This suggests that the primed $\mathrm{CO}_{2}$ was derived from the reutilization of microbial necromass (produced after a strong decrease in microbial biomass), indicating that necromass served as an SOM primer. However, negligible or no $\mathrm{PE}$ corresponded with stable microbial biomass in conventional and forest soils. $\mathrm{N}$ addition with $\mathrm{C}$ resulted in reduced SOM decomposition in conventional and forest soil, which supports the preferential microbial substrate utilization theory. This implies that microorganisms prefer to utilize added $\mathrm{C}$ and $\mathrm{N}$ instead of decomposing SOM to fulfill their energy and nutrient requirements. In contrast to the suppressive effects of $\mathrm{N}, \mathrm{P}$ addition in combination with $C$ enhanced microbial respiration in all land use systems. This could be attributed to increases in microbial biomass and their resulting increased nutrient (i.e. $N$ ) demands. The accelerated SOM decomposition following combined $\mathrm{N}$ and $\mathrm{P}$ addition was more pronounced than for single nutrient additions, supporting the theory of stoichiometric decomposition in organic soil. SOM decomposition responded more to $\mathrm{N}$ than to $\mathrm{P}$ addition in conventional and forest soils, resulting in negative PEs after multiple nutrients addition. Our findings suggest that the direction and magnitude of SOM decomposition is regulated by the availability of essential nutrients under different land use systems.

\subsubsection{Acknowledgements}

We acknowledge the Erasmus mundus (Experst4Asia) for financial support of Menuka Maharjan and Chinese Academy of Science (CAS) for Huadong Zang. The authors would like to thank Karin Schmidt and Anita Kriegel for laboratory assistance, and Sandesh Bhatta and Bibek Thapa for field work assistance.

\subsubsection{References}

Blagodatskaya, E., Khomyakov, N., Myachina, O., Bogomolova, I., Blagodatsky, S., Kuzyakov, Y., 2014. Microbial interactions affect sources of priming induced by cellulose. Soil Biol. Biochem. 74, 39-49. doi:10.1016/j.soilbio.2014.02.017

Blagodatskaya, E., Kuzyakov, Y., 2008. Mechanisms of real and apparent priming effects and their dependence on soil microbial biomass and community structure: critical review. Biol. Fertil. Soils 45, 115-131. doi:10.1007/s00374-008-0334-y

Bobbink, A.R., Hicks, K., Galloway, J., Spranger, T., Alkemade, R., Ashmore, M., Cinderby, S., Davidson, E., Dentener, F., Emmett, B., Erisman, J., Fenn, M., Nordin, A., Pardo, L., Vries, W. De, Hicks, K., Galloway, J., Bobbink, R., Davidson, E., Dentener, F., Cinderby, S., 
Spranger, T., Bustamante, M., 2010. Global assessment of nitrogen deposition effects on terrestrial plant diversity: Asynthesis. Ecol. Appl. 20, 30-59.

Chen, H., Billen, N., Stahr, K., Kuzyakov, Y., 2007. Effects of nitrogen and intensive mixing on decomposition of $14 \mathrm{C}$-labelled maize (Zea mays L.) residue in soils of different land use types. Soil Tillage Res. 96, 114-123. doi:10.1016/j.still.2007.04.004

Cheng, W., Kuzyakov, Y., 2005. Root Effects on Soil Organic Matter Decomposition, Agronomy. doi:doi:10.2134/agronmonogr48.c7

Cheng, W., Parton, W.J., Gonzalez-meler, M.A., Phillips, R., Asao, S., Mcnickle, G.G., Brzostek, E., Jastrow, J.D., 2014. Tansley review Synthesis and modeling perspectives of rhizosphere priming 31-44.

Christensen, B.T., Johnston, A.E., 1997. No TitleSoil organic matter and soil quality-lessons learned from long-term experiments at Askov and Rothamsted. Elsevier, Amsterdam, NI.

Clarholm, M., 1985. Interactions of bacteria, protozoa and plants leading to mineralization of soil nitrogen. Soil Biol. Biochem. 17, 181-187. doi:10.1016/0038-0717(85)90113-0

Cleveland, C.C., Townsend, A.R., 2006. Nutrient additions to a tropical rain forest drive substantial soil carbon dioxide losses to the atmosphere. Proc. Natl. Acad. Sci. U. S. A. 103, 1031610321. doi:10.1073/pnas.0600989103

Cleveland, C.C., Townsend, A.R., Schmidt, S.K., 2002. Phosphorus Limitation of Microbial Processes in Moist Tropical Forests: Evidence from Short-term Laboratory Incubations and Field Studies. Ecosystems 5, 0680-0691. doi:10.1007/s10021-002-0202-9

Craine, J.M., Morrow, C., Fierer, N., 2007. Microbial nitrogen limitaiton increases decompostion. Ecology 88, 2105-2113. doi:10.1890/06-1847.1

Dijkstra, F.A., Carrillo, Y., Pendall, E., Morgan, J.A., 2013. Rhizosphere priming: A nutrient perspective. Front. Microbiol. 4, 1-8. doi:10.3389/fmicb.2013.00216

Fisk, M., Santangelo, S., Minick, K., 2015. Carbon mineralization is promoted by phosphorus and reduced by nitrogen addition in the organic horizon of northern hardwood forests. Soil Biol. Biochem. 81, 212-218. doi:10.1016/j.soilbio.2014.11.022

Fornara, D.A., Banin, L., Crawley, M.J., 2013. Multi-nutrient vs. nitrogen-only effects on carbon sequestration in grassland soils. Glob. Chang. Biol. 19, 3848-3857. doi:10.1111/gcb.12323

Guillaume, T., Damris, M., Kuzyakov, Y., 2015. Losses of soil carbon by converting tropical forest to plantations: erosion and decomposition estimated by $\delta(13)$ C. Glob. Chang. Biol. 21, 354860. doi:10.1111/gcb.12907

Houghton, R., 2012. Historic changes in terrestrial carbon storage. In: Lal, R., Lorenz, K.,Hüttl R, F., Schneid er, B.U., von Braun, J. (Eds.), Recarbonization of the Biosphere. Springer, pp. S. 59-S. 82IUSS Working Group WRB, 2015. World Reference Base for Soil Resources for 2014. World Soil Resources Report No. 106. FAO, Rome, 203 pp.

Janssens, I.A., Dieleman, W., Luyssaert, S., Subke, J.-A., Reichstein, M., Ceulemans, R., Ciais, P., Dolman, A.J., Grace, J., Matteucci, G., Papale, D., Piao, S.L., Schulze, E.-D., Tang, J., Law, B.E., 2010. Reduction of forest soil respiration in response to nitrogen deposition. Nat. Geosci. 3, 315-322. doi:10.1038/ngeo844

Kutsch, W.L., Aubinet, M., Buchmann, N., Smith, P., Osborne, B., Eugster, W., Wattenbach, M., Schrumpf, M., Schulze, E.D., Tomelleri, E., Ceschia, E., Bernhofer, C., Béziat, P., Carrara, A., Di Tommasi, P., Grünwald, T., Jones, M., Magliulo, V., Marloie, O., Moureaux, C., Olioso, A., Sanz, M.J., Saunders, M., Søgaard, H., Ziegler, W., 2010. The net biome production of full crop rotations in Europe. Agric. Ecosyst. Environ. 139, 336-345. doi:10.1016/j.agee.2010.07.016

Kuzyakov, Y., 2002. Review: Factors affecting rhizosphere priming effects. J. Plant Nutr. Soil Sci. 165, 382-396.

Lal, R., 2004. Soil carbon sequestration impacts on global climate change and food security. Science 304, 1623-7. doi:10.1126/science.1097396

Liu, L., Greaver, T.L., 2010. A global perspective on belowground carbon dynamics under nitrogen enrichment. Ecol. Lett. 13, 819-828. doi:10.1111/j.1461-0248.2010.01482.x

MA, 2005. Ecosystems and Human Well-Being: Synthesis. Island Press, Washington, DC.

Maharjan, M., Sanaullah, M., Razavi, B.S., Kuzyakov, Y., 2017. Effect of land use and management practices on microbial biomass and enzyme activities in subtropical top-and sub-soils. Appl. Soil Ecol. 113, 22-28. doi:10.1016/j.apsoil.2017.01.008

Maharjan, M., Sanaullah, M., Razavi, B.S., Kuzyakov, Y., 2017. Effect of land use and management practices on microbial biomass and enzyme activities in subtropical top-and sub-soils. Appl. Soil Ecol. 113. doi:10.1016/j.apsoil.2017.01.008 
Mason-Jones, K., Kuzyakov, Y., 2017. "Non-metabolizable" glucose analogue shines new light on priming mechanisms: Triggering of microbial metabolism. Soil Biol. Biochem. 107, 68-76. doi:10.1016/j.soilbio.2016.12.015

Meyer, N., Welp, G., Bornemann, L., Amelung, W., 2017. Soil Biology \& Biochemistry Microbial nitrogen mining affects spatio-temporal patterns of substrate-induced respiration during seven years of bare fallow. Soil Biol. Biochem. 104, 175-184. doi:10.1016/j.soilbio.2016.10.019

Miltner, A., Bombach, P., Schmidt-Brücken, B., Kästner, M., 2012. SOM genesis: Microbial biomass as a significant source. Biogeochemistry 111, 41-55. doi:10.1007/s10533-011-9658-z

Miltner, A., Kindler, R., Knicker, H., Richnow, H., Kästner, M., 2009. Organic Geochemistry Fate of microbial biomass-derived amino acids in soil and their contribution to soil organic matter. Org. Geochem. 40, 978-985. doi:10.1016/j.orggeochem.2009.06.008

Moorhead, D.L., Sinsabaugh, R.L., 2006. A theoretical mode of litter decay and micorbial interaction. Ecol. Monogr. 76, 151-174. doi:10.1890/0012-9615(2006)076[0151:ATMOLD]2.0.CO;2

Nadelhoffer, K.J., Emmett, B.A., Gundersen, P., Kjùnaas, O.J., Koopmans, C.J., Schleppi, P., Tietema, A., Wright, R.F., 1999. Nitrogen deposition makes a minor contribution to carbon sequestration in temperate forests $398,1997-2000$.

Paterson, E., Midwood, A.J., Millard, P., 2009. Through the eye of the needle: A review of isotope approaches to quantify microbial processes mediating soil carbon balance. New Phytol. 184, 19-33. doi:10.1111/j.1469-8137.2009.03001.x

Poeplau, C., Herrmann, A.M., Thomas, K., 2016. Opposing effects of nitrogen and phosphorus on soil microbial metabolism and the implications for soil carbon storage. Soil Biol. Biochem. 100, 83-91. doi:10.1016/j.soilbio.2016.05.021

Ramirez, K.S., Craine, J.M., Fierer, N., 2012. Consistent effects of nitrogen amendments on soil microbial communities and processes across biomes. Glob. Chang. Biol. 18, 1918-1927. doi:10.1111/j.1365-2486.2012.02639.x

Reed, S.C., Vitousek, P.M., Cleveland, C.C., 2011. Are patterns in nutrient limitation belowground consistent with those aboveground: Results from a 4 million year chronosequence. Biogeochemistry 106, 323-336. doi:10.1007/s10533-010-9522-6

Salazar-Villegas, A., Blagodatskaya, E., Dukes, J.S., 2016. Changes in the size of the active microbial pool explain short-term soil respiratory responses to temperature and moisture. Front. Microbiol. 7, 1-10. doi:10.3389/fmicb.2016.00524

Shahbaz, M., Kuzyakov, Y., Heitkamp, F., 2015. Decrease of soil organic matter stabilization with increasing inputs: Mechanisms and controls. Geoderma. doi:10.1016/j.geoderma.2016.05.019

Shahbaz, M., Kuzyakov, Y., Sanaullah, M., Heitkamp, F., Zelenev, V., Kumar, A., Blagodatskaya, E., 2017. Microbial decomposition of soil organic matter is mediated by quality and quantity of crop residues: mechanisms and thresholds. Biol. Fertil. Soils 1-15. doi:10.1007/s00374016-1174-9

Six, J., Feller, C., Denef, K., Ogle, S.M., Sa, J.C.D., Albrecht, A., 2002. No TitleSoil organic matter, biota, and aggregation in temperate and tropical soils-effects of no-tillage. Agronomie 22, 755-775.

Smith, W.., Desjardins, R.., Pattey, E., 2000. The net flux of carbon from agricultural soils in Canada. Glob. Chang. Biol. 557-568.

Torn, M.S., Vitousek, P.M., Trumbore, S.E., 2005. The influence of nutrient availability on soil organic matter turnover estimated by incubations and radiocarbon modeling. Ecosystems 8 , 352-372. doi:10.1007/s10021-004-0259-8

Townsend, A.R., Braswell, B.H., Holland, E.A., Penner, J.E., 1996. No TitleSpatial and temporal patterns in terrestrial carbon storage due to deposition of fossil fuel nitrogen. Ecol. Appl 6, 806-814.

Townsend, A.R., Cleveland, C.C., Houlton, B.Z., Alden, C.B., White, J.W.C., 2011. Multi-element regulation of the tropical forest carbon cycle. Front. Ecol. Environ. 9, 9-17. doi:10.1890/100047

van Noordwijk, M., Cerri, C., Woomer, P.L., Nugroho, K., Bernoux, M., 1997. Soil carbon dynamics in the humid tropical forest zone. Geoderma 79, 187-225. doi:10.1016/S00167061(97)00042-6

Vance, E.D., Brookes, P.C., Jenkinson, D.S., 1987. An extraction method for measuring soil microbial biomass C. Soil Biol. Biochem. 19, 703-707. doi:10.1016/0038-0717(87)90052-6 
Waldrop, M.P., Zak, D.R., 2006. Response of oxidative enzyme activities to nitrogen deposition affects soil concentrations of dissolved organic carbon. Ecosystems 9, 921-933. doi:10.1007/s10021-004-0149-0

West, T.., Post, W.., 2002. Soil Organic Carbon Sequestration Rates by Tillage and Crop Rotation: A Global Data Analysis. Soil Sci.Soc. Am.J. 66, 1930-1946.

\subsubsection{Supporting information}

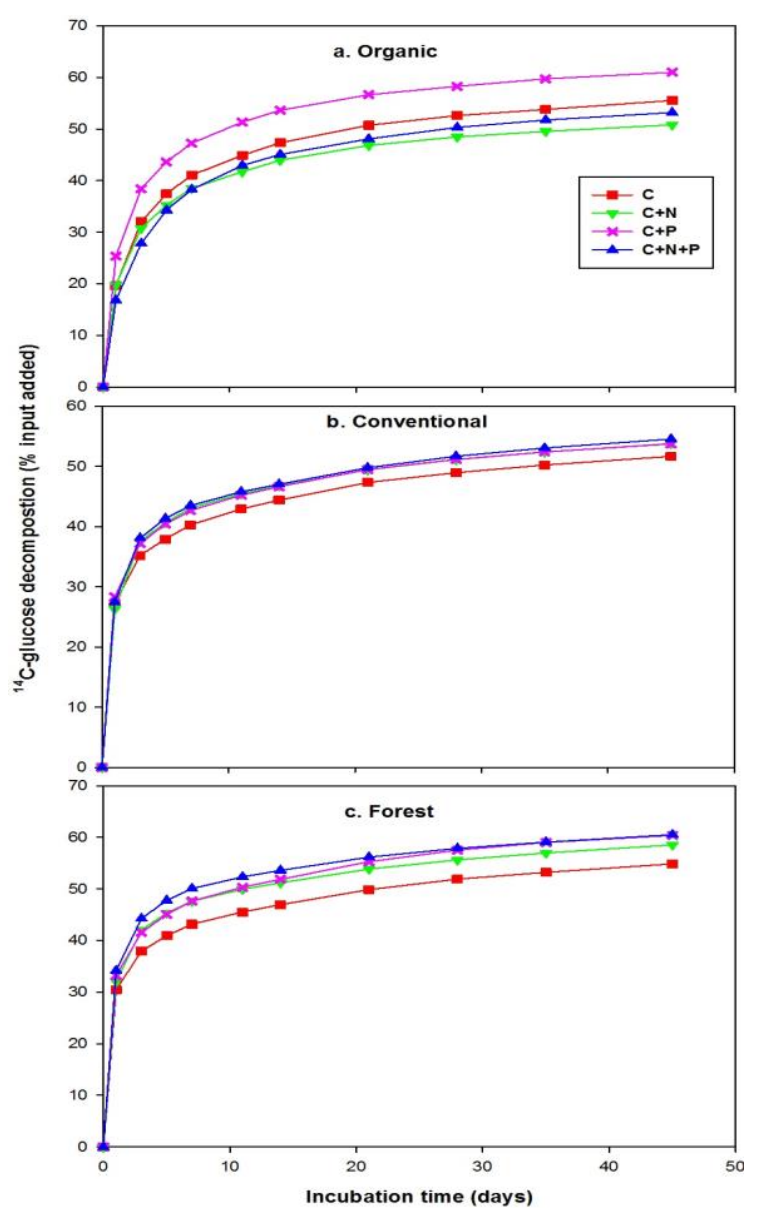

Figure S1 Cumulative ${ }^{14} \mathrm{C}$-glucose decomposition in soil under organic farming (a), conventional farming, (b) and forest (c). $\mathrm{C}, \mathrm{C}+\mathrm{N}, \mathrm{C}+\mathrm{P}$, and $\mathrm{C}+\mathrm{N}+\mathrm{P}$ in the figure represent the addition of glucose only, glucose + nitrogen, glucose + phosphorus, glucose + nitrogen + phosphorus, respectively. Values are means \pm standard error $(n=4)$. 


\title{
3.4 Study 4: Microbial necromass as a source of priming regulated by microbial growth strategies
}

\author{
Menuka Maharian $^{1,2^{*}}$, Aliia Gilmullina ${ }^{3}$, Huadong Zang $^{3}$, Yakov Kuzyakova ${ }^{1,3}$, \\ Evgenia Blagodatskaya ${ }^{1,4}$ \\ Status: In preparation \\ ${ }^{1}$ Department of Soil Science of Temperate Ecosystems, University of Göttingen, Göttingen, Germany \\ ${ }^{2}$ Institute of Forestry, Tribhuwan University, Hetauda, Makwanpur, Nepal \\ ${ }^{3}$ Departments of Agricultural Soil Science, University of Göttingen, Göttingen, Germany \\ ${ }^{4}$ Institutes of Physicochemical and Biological Problems in Soil Science, Pushchino, Russia
}

\subsubsection{Abstract}

Decomposition of soil organic matter (SOM) significantly affects the soil organic carbon pool, contributing to greenhouse gas emissions and climate change. However, the mechanism behind environmental-induced alterations to SOM decomposition has yet to be elucidated. In natural ecosystems, soil under different land use systems exhibits diverse soil and microbial properties, all of which constitute soil quality. Soil under organic farming, conventional farming, and forest may be classified as rich, medium, and poor quality, respectively, due to different management practices. Differences in soil quality support diverse microbial growth strategies i.e. $r, \mathrm{~K}$ and L- strategists in soil under organic farming, conventional farming, and forest, respectively. $r$ - strategists form necromass via autolysis to cope with starvation, which corresponded with decreasing microbial biomass at the end of incubation. The surviving microorganisms were activated by utilizing the resultant necromass as source of substrate. This lead to increased SOM decomposition to fulfill the heightened nutrient requirements of activated microorganisms, which was evident from the positive PE in rich soil under organic farming. K- strategists went into dormancy, while Lstrategists remained stable under starvation, reflecting negligible to fluctuating $P E$ in medium quality soil under conventional farming and poor quality soil under forest, respectively. In conclusion, microbial growth strategies, which are influenced by soil quality, regulate the decomposition of $\mathrm{SOM}$, revealing soil quality as the driver of $\mathrm{PE}$ in ecosystems.

Keywords: Priming effect; microbial-necromass, soil quality, microbial growth strategies Corresponding Author: Menuka Maharjan, menuka48maharjangmail.com 


\subsubsection{Introduction}

Soil organic matter (SOM) is recognized as the largest pool in the global terrestrial carbon (C) cycle and is thus a vital factor in global $\mathrm{CO}_{2}$ emissions or sequestration (Schlesinger, 1977; Jobbágy and Jackson, 2000). Any alteration in stocks of SOM will, therefore, have significant effects on the concentrations of atmospheric $\mathrm{CO}_{2}$ (Bellamy et al., 2005).

Decomposition of SOM is a vital process that is mediated by soil microorganisms. It has long been recognized that decomposition of SOM is significantly affected by the input of labile substrates. Furthermore, PE is the phenomenon that describes changes in decomposition of SOM due to changes in microbial activity as a response to change in amounts and availability of organic $C$ and nutrients (Kuzyakov, 2010). Although priming effects after substrate addition have been extensively studied, most prior studies concentrated on reporting the magnitude of priming effects instead of the underlying mechanisms (Blagodatskaya and Kuzyakov, 2008). Most of the primary sources of labile organics in soil are of plant origin, i.e., root exudates, rhizodepositon, plant residues, etc. (De Nobili et al., 2001; Dijkstra et al., 2006; Chen et al., 2015; Shahbaz et al., 2017). Plantbased organic compounds are processed by microorganisms and immobilized in microbial biomass. Microbial residues, therefore, represent a potential secondary source of PE. According to the purposed hypothesis (Miltner et al., 2009), microorganisms reduce their biomass under starvation and other unfavorable conditions. This leads to accumulation of microbial residues, known as necromass. The recalcitrant parts of microbial necromass (i.e., undecomposed components of cell envelopes) strongly contribute to the formation of stable SOM (Miltner et al., 2012; Wagner, 1968). The labile parts of microbial-necromass (e.g., cytosol ingredients) serve as available substrates for the surviving microorganisms, who re-utilize this necromass. Thus, the labile fraction of microbial necromass can contribute to priming by stimulating the decomposition of recalcitrant SOM (Shahbaz et al., 2017). As the mechanisms of necromass formation in soil are not fully understood, here we propose an explanation which transfers the concept of common ecological strategies (Pianka, 1970) to the level of the soil microbial community. According to this concept, microbial populations exploit one of the three major life strategies $\mathrm{r}$-, K- and L-strategists with the composition and size of active fraction dependent on environmental conditions (Swift et al., 1979). Among the three, the L- strategy is considered as stress tolerant and the $r$ - strategy as fast growing in favorable environments but quickly failing in under any limitations. The K- strategy is characterized by universal slow and efficient growth in nearly all environments. In soil, however, the life strategy is not strictly fixed for individual microbial species, and microorganism can shift their strategy depending on the 
environmental conditions. According to the microbial competition concept, K-strategists actively participate in decomposition of SOM by outcompeting $r$-strategists after exhaustion of labile substrates, thus inducing a real PE (Fontaine et al., 2003). However, both K-and rstrategists were able to induce PE by contrasting mechanisms depending on the availability of nutrients (Chen et al., 2014). In contrast to L- and K-strategists maintaining their populations at the relatively stable level, the r-strategists strongly reduce their populations under starvation conditions in batch cultures. The ability to quickly upregulate growth rates enables the r-strategists to out-compete the other microorganisms and quickly recover their population following input of fresh substrate. Therefore, under unfavorable conditions, $r$ strategists do not maintain their population. Instead, they activate the mechanisms of biomass reduction (e.g., by autolysis), producing necromass which serves as a substrate for the surviving microorganisms. Hence, $r$-strategists can form necromass and contribute to $\mathrm{PE}$, and thus represent a microbial functional group with a strong potential to accelerate the decomposition of SOM. Therefore, accurate estimation of the dominant growth strategy for the microbial population is essential to determine the underlying mechanisms behind the PE. Determining the different functional groups in an individual microbial community is still a technically challenging task (Mau et al., 2015), but can be accomplished via the kinetic approach for estimating specific microbial growth rates (De Nobili et al., 2001; Blagodatskaya et al., 2007). Despite theoretical evidence, the concept that the priming effect may result from necromass formation in soils dominated by fast-growing ( $r$-strategist) populations has yet to be proven experimentally.

As microbial communities are very responsive to changing environmental conditions (Coleman et al., 2004; Heaton et al., 2012), we choose three different land use sites with contrasting soil properties forest (poor), conventional (medium) and organic farming (rich) but similar climatic conditions. This provides an opportunity to identify the existence of different microbial strategies under diverse soil conditions. Thus, this study was performed to link microbial growth parameters with observed priming effects in response to substrate addition in tropical land use systems. We hypothesized that in soil dominated by fastgrowing microorganisms, a decrease in microbial biomass can be detected under starvation conditions. Our second hypothesis was that a decrease in microbial biomass would be accompanied by increases in PE. To test these hypotheses, we conducted a laboratory incubation experiment with soils from three land use systems after addition of $14 \mathrm{C}$-labelled glucose. This allowed us to examine the effect of the added $\mathrm{C}$ on $\mathrm{CO}_{2}$ emissions and microbial biomass. We also measured microbial growth parameters in situ via the kinetic approach based on substrate-induced growth respiration 


\subsubsection{Methodology}

\subsubsection{Site description and soil sampling}

Soil samples were collected from three land use systems (organic farming, conventional farming, and forest) in the Chitwan district $\left(27^{\circ} 35^{\prime} \mathrm{N} 84^{\circ} 30^{\prime} \mathrm{E}\right)$ of Nepal. The climate of this area is subtropical with an average temperature of $30^{\circ} \mathrm{C}$ and annual rainfall of $1763 \mathrm{~mm}$. The texture of the soil is sandy loam. The organic farm has been under organic management for 15 years. The crop rotation is maize+rice+vegetables/mustard in organic farming and maize+rice+wheat/lentils in conventional farming. About 10 ton ha ${ }^{-1} \mathrm{yr}^{-1}$ of farmyard manure and vermicomposting are applied in organic farming whereas urea $(60 \mathrm{~kg}$ $\mathrm{ha}^{-1} \mathrm{yr}^{-1}$ ) and potassium (15 kg ha- $\mathrm{yr}^{-1}$ ) in conventional farming. Although forest is dominated by broad leaf Shorea robusta, leaf litters are collected by villagers for social and religious activities. Pesticides are applied only in conventional farming. Detailed descriptions of the study sites are provided in Maharjan et al., (2017).

Soil samples were collected from the upper 0-20 from four random sampling locations in each land use system. Fine roots, plant remains, and debris were carefully removed using tweezers. The samples were kept cold $\left(\sim 4^{\circ} \mathrm{C}\right)$ prior to analysis. The soils are classified as Gleyic Cambisols for the organic farm and forest, and Eutric Cambisol for the conventional farm (IUSS Working Group WRB, 2015). The chemical properties of the soils under different land-use system are presented in Table 1.

Table 1 Description of chemical properties of soils

\begin{tabular}{|c|c|c|c|c|}
\hline Land use & Total C (\%) & Total N (\%) & Total P (mg P kg-1 soil) & $\mathrm{pH}\left(\mathrm{H}_{2} \mathrm{O}\right)$ \\
\hline $\begin{array}{l}\text { Organic farming }= \\
15 \text { years }\end{array}$ & 1.7 & 0.16 & 332.2 & 7.5 \\
\hline $\begin{array}{l}\text { Conventional } \\
\text { farming }\end{array}$ & 1.3 & 0.11 & 130.0 & 5.0 \\
\hline Forest & 0.7 & 0.06 & 89.4 & 5.5 \\
\hline
\end{tabular}

\subsubsection{Experimental design}

About $22 \mathrm{~g}$ (oven-dried weight) of the soil from three land use was weighed into a 100-ml jar. The soil was adjusted to $60 \%$ of $\mathrm{WHC}$ and pre-incubated for 30 days at $22^{\circ} \mathrm{C}$. There were two treatments in each land use: 1) water, the control, 2) C. After 30 days preincubation, soil was amended either with distilled water (control) or with glucose at the 
rates of $239 \mu \mathrm{g} \mathrm{C} \mathrm{g}^{-1}$ soil, $184 \mu \mathrm{g} \mathrm{g} \mathrm{g}^{-1}$ soil, and $132 \mu \mathrm{g} \mathrm{C} \mathrm{g}{ }^{-1}$ soil in organic farming, conventional farming, and forest, respectively. The amount of glucose addition was equivalent to $30 \%$ of initial microbial biomass carbon (MBC) in three land use system. Uniformly labeled 14C glucose (final activity of $7514 \mathrm{DPM} \mathrm{g}^{-1}$ soil, $7401 \mathrm{DPM} \mathrm{g}^{-1}$ soil, and 7485 DPM g$^{-1}$ soil in organic farming, conventional farming, and forest, respectively) was added to unlabeled glucose before adding to soil. Glucose was applied to soil as a solution to reach final soil moisture content of $70 \%$ of WHC. Each treatment has four replicates in respective land use system for each sampling date.

\subsubsection{Incubation and sampling}

After adding distilled water or glucose solution to the soil, small vials with $3 \mathrm{ml}$ of $1 \mathrm{M} \mathrm{NaOH}$ were placed in the incubation vessels to trap $\mathrm{CO}_{2}$. The vessels were immediately closed air-tight and incubated for 45 days at $22^{\circ} \mathrm{C}$ and maintained at $70 \% \mathrm{WHC}$ throughout the incubation period. The vials with $\mathrm{NaOH}$ were removed and replaced by new vials at $1,3,5$, $7,11,14,21,28,35$, and 45 days. $\mathrm{CO}_{2}$ trapped in $\mathrm{NaOH}$ solution was precipitated with 0.5 $\mathrm{M} \mathrm{BaCl}_{2}$ solution. The total amount of $\mathrm{CO}_{2}$ trapped in the vials was measured by titration of $0.25 \mathrm{ml}$ of $\mathrm{NaOH}$ solution with $0.025 \mathrm{M} \mathrm{HCl}$ using phenolphthalein as indicator. For ${ }^{14} \mathrm{C}$ activity measurement, $1 \mathrm{ml}$ of ${ }^{14} \mathrm{CO}_{2}$ enriched $\mathrm{NaOH}$ from the $\mathrm{CO}_{2}$ traps mixed with $3 \mathrm{ml}$ of the scintillation cocktail Rotiszint EcoPlus (Carl Roth Company, Germany) and was measured using a Hidex 300 SL Automatic TDCR Liquid Scintillation Counter (Beckman Coulter Inc., USA). Before measuring, the samples were properly mixed and homogenized for $10 \mathrm{~s}$ using Vortex genie 2 (Scientific Industries INC, USA), and kept overnight. The ${ }^{14} \mathrm{C}$ counting efficiency and the ${ }^{14} \mathrm{C}$ activity measurement error maintained about $80 \%$ and $2 \%$ respectively.

\subsubsection{Microbial biomass}

Microbial biomass was measured at the end of the incubation period and determined by the chloroform fumigation method (Vance et al., 1987). About $4 \mathrm{~g}$ of soil was extracted with 20 $\mathrm{ml}$ of $0.05 \mathrm{M} \mathrm{K}_{2} \mathrm{SO}_{4}$. Another $4 \mathrm{~g}$ of soil were firstly fumigated with chloroform for $24 \mathrm{~h}$ and then extracted in the same way. The extracts were analyzed for the total $\mathrm{C}$ concentration using a 2100 TOC/TIC analyzer (Analytik Jena, Germany). The extracts of the nonfumigated samples were used to measure dissolved organic carbon (DOC). The total amount of extractable microbial biomass $\mathrm{C}(\mathrm{MBC})$ was calculated based on the difference of $\mathrm{K}_{2} \mathrm{SO}_{4}$-extracable $\mathrm{C}$ between fumigated and non-fumigated soil samples using the $\mathrm{k}_{\mathrm{EC}}$ factor 0.45 (Joergensen 1996). The ${ }^{14} \mathrm{C}$ activity both in fumigated and non-fumigated extracts was measured using the above procedure (as ${ }^{14} \mathrm{C}$ in $\mathrm{CO}_{2}$ ) in $5 \mathrm{ml}$ aliquot added to 
$15 \mathrm{ml}$ of scintillation cocktail. The ${ }^{14} \mathrm{C}$ activity in microbial biomass was calculated by taking the difference of the activities from fumigated and non-fumigated samples.

\subsubsection{Kinetics parameters of microbial growth}

The kinetic parameters of microbial growth responses were estimated according to the modified method of (Blagodatsky et al., 2000). Soil samples (equivalent to $0.5 \mathrm{~g}$ dry soil) were amended with a solution $(50 \mu \mathrm{l})$ containing glucose $\left(10 \mathrm{mg} \mathrm{g}^{-1}\right.$ of soil) and a salt solution: $\left(\mathrm{NH}_{4}\right)_{2} \mathrm{SO}_{4} 1.9 \mathrm{mg} \mathrm{g}^{-1}$ and $\mathrm{MgSO} 4{ }^{*} 7 \mathrm{H}_{2} \mathrm{O} 3.8 \mathrm{mg} \mathrm{g}^{-1}$ of soil. The salt solution contained different concentrations of $\mathrm{K}_{2} \mathrm{HPO}_{4}$ for organic farming (2.03 $\mathrm{mg} \mathrm{g}^{-1}$ soil), conventional farming $\left(0.16 \mathrm{mg} \mathrm{g}^{-1}\right.$ soil), and forest soil $\left(0.50 \mathrm{mg} \mathrm{g}^{-1}\right.$ soil). Similarly, the concentration of $\mathrm{KH}_{2} \mathrm{PO}_{4}$ was $0.18,1.63$, and $1.9 \mathrm{mg} \mathrm{g}^{-1}$ for soil under organic farming, conventional farming, and forest, respectively. The amount of mineral salts was selected based on the soil $\mathrm{pH}$ and buffering capacity to change soil $\mathrm{pH}$ less than 0.1 after substrate addition (Blagodatskaya et al., 2007). Immediately after addition of substrate, eppendrop containing soil sample was placed in plastic tubes containing $3 \mathrm{ml}$ of $\mathrm{NaOH}$. Then each cell was inserted into a RABBIT (The Rapid Automated Bacterial Impedance Technique) system for measuring the $\mathrm{CO}_{2}$ emission at $25^{\circ} \mathrm{C}$ for $59 \mathrm{~h}$ (Gilmullina et al., 2017). The following equation was used to calculating $\mathrm{CO}_{2}$ emissions (Gilmullina et al. 2017).

$\mathrm{C}\left(\mathrm{C}-\mathrm{CO}_{2}\right)=\left(0.383^{*} \Delta \mathrm{EC}\right) * \mathrm{~V} / \mathrm{m}$

Where $\mathrm{C}\left(\mathrm{C}-\mathrm{CO}_{2}\right)$ ) is $\left.\mathrm{C}-\mathrm{CO}_{2}\right)$ concentration ( $\mu \mathrm{g} \mathrm{g}^{-1}$ soil), $\Delta \mathrm{EC}$ is electrical conductivity change $(\mu \mathrm{s}), V$ is volume of alkali $(\mathrm{ml})$ and $\mathrm{m}$ is weight of dry soil $(\mathrm{g})$.

Maximum specific growth rate $(\mu \mathrm{m})$ of soil microorganisms was estimated by fitting the parameters of the equation.

$\mathrm{CO}_{2}(\mathrm{t})=\mathrm{A}+\mathrm{B} \exp (\mu \mathrm{m} * \mathrm{t})$

Where $A$ is the initial respiration rate uncoupled from ATP generation, $B$ is the initial rate of the growing fraction of total respiration coupled with ATP generation and cell growth, $\mu \mathrm{m}$ is the maximal specific growth rate of soil microorganisms, and $t$ is time (Panikov and Sizova, 1996) (Blagodatsky et al., 2000). The parameters of Eq. (2) were fitted by minimizing the least-square sum using Model Maker-3 software (SB Technology Ltd.). Three replication in each land use were used for respiration curves and growth parameters.

Lag period ( $T_{\text {lag }}$ ) calculated from Eqn (3) (Blagodatsky et al., 2000). Total microbial biomass ( $\mu \mathrm{g} \mathrm{C} \mathrm{g}{ }^{-1}$ soil) calculated by substrate induced respiration i.e. Eqn (4) (Anderson and 
Domsch, 1978) (Hoang et al., 2016) and \% of active microbial biomass (\% AMB, $\mu \mathrm{g} \mathrm{C} \mathrm{g}^{-1}$ soil) were calculated by Eqn (5) equation (Blagodatsky et al., 2000).

$\mathrm{T}_{\mathrm{lag}}=\ln (\mathrm{A} / \mathrm{B}) / \mu$

$\mathrm{TMB}=40.4^{*} \mathrm{y}+0.37$

$\% \mathrm{AMB}=\mathrm{TMB}{ }^{*} \mathrm{r}_{0}$

In equation (3), $y$ is initial rate of substate-induced respiration after soil amendment with glucose and salt mixture solution. In equation (5) $r_{0}$ is the so-called physiological state index of the microbial biomass (MB) and was calculated from Eqn (6). $Q$ is the total specific respiration activity and was calculated from Eqn (7).

$r_{0}=B(1-\lambda) / A+B(1-\lambda)$

where $\lambda$ means basic stoichiometric constant value i.e. 0.9 (Panikov and Sizova, 1996)

$\mathrm{Q}=\mu / \lambda \mathrm{YcO}_{2}$

The theory of the microbial growth kinetics was presented in detail (Panikov, 1995).

\subsubsection{Calculations and statistical analysis}

The amount of glucose-derived $\mathrm{C}\left(\mathrm{C}_{\mathrm{G} \text {-derived }}\right)$ was calculated based on the current ${ }^{14} \mathrm{C}$ radioactivity $\left({ }^{14} \mathrm{C}_{\text {curr }}\right)$, the amount of added glucose $\left({ }^{14} \mathrm{C}_{\mathrm{G}}\right)$, and the initial radioactivity of the added glucose $\left({ }^{14} \mathrm{C}_{\text {inital }}\right)$ in each land use-system:

$\mathrm{C}_{\mathrm{G} \text {-derived }}={ }^{14} \mathrm{C}_{\text {curr }}{ }^{*} \mathrm{CG} /{ }^{14} \mathrm{C}_{\text {initial }}$

Then, SOM-derived C was calculated by following equation:

$\mathrm{C}_{\text {SOM-derived }}=\mathrm{C}_{\text {total }}-\mathrm{C}_{\mathrm{G} \text {-derived }}$

where $\mathrm{C}$ total is the total amount of $\mathrm{C}$ in the corresponding pool $\left(\mathrm{CO}_{2}\right.$, $\mathrm{DOC}$, microbial biomass).

At the final, priming effects (PE) were calculated by using following equation:

$\mathrm{PE}=\left[\mathrm{CO}_{2}\right]_{\text {treatment }}-\left[\mathrm{CO}_{2}\right]_{\mathrm{G}}-\left[\mathrm{CO}_{2}\right]_{\text {control }}$

where $\left[\mathrm{CO}_{2}\right]$ treatment, $\left[\mathrm{CO}_{2}\right]$ G and $\left[\mathrm{CO}_{2}\right]$ control represent $\mathrm{CO}_{2}$ emissions from soil after nutrients treatments, only glucose treatment and without any amendment, respectively. 
The effect of nutrients amendment on $\mathrm{CO}_{2}$ rate, cumulative $\mathrm{CO}_{2}$, priming effect, $\mathrm{MBC}$ and growth parameters in different land-use system were analyzed using one-way analysis of variance (ANOVA) at a significance level of $p<0.05$ using the statistical software Statistica 12. The data which didn't pass homogeneity test were log transferred.

\subsubsection{Results}

\subsubsection{Cumulative $\mathrm{CO}_{2}$ and priming effects}

Over the 45 day incubation period, $\mathrm{C}$ addition significantly accelerated the decomposition of SOM in organic farming soils (Fig.1). A slight PE was initially detectable (5 $\mathrm{g} \mathrm{C} \mathrm{g}^{-1}$ soil), but significant increases were only observed after two weeks of incubation (> $20 \mu \mathrm{g} \mathrm{C} \mathrm{g}^{-1}$ soil). The significant increase in SOM-derived $\mathrm{CO}_{2}$ emissions at the conclusion of the experiment indicated a strong positive PE (37 $\mathrm{g} \mathrm{C} \mathrm{g}^{-1}$ soil). However, relatively low positive PE was observed in conventional farming and forest soils throughout the incubation period (Fig. 1).
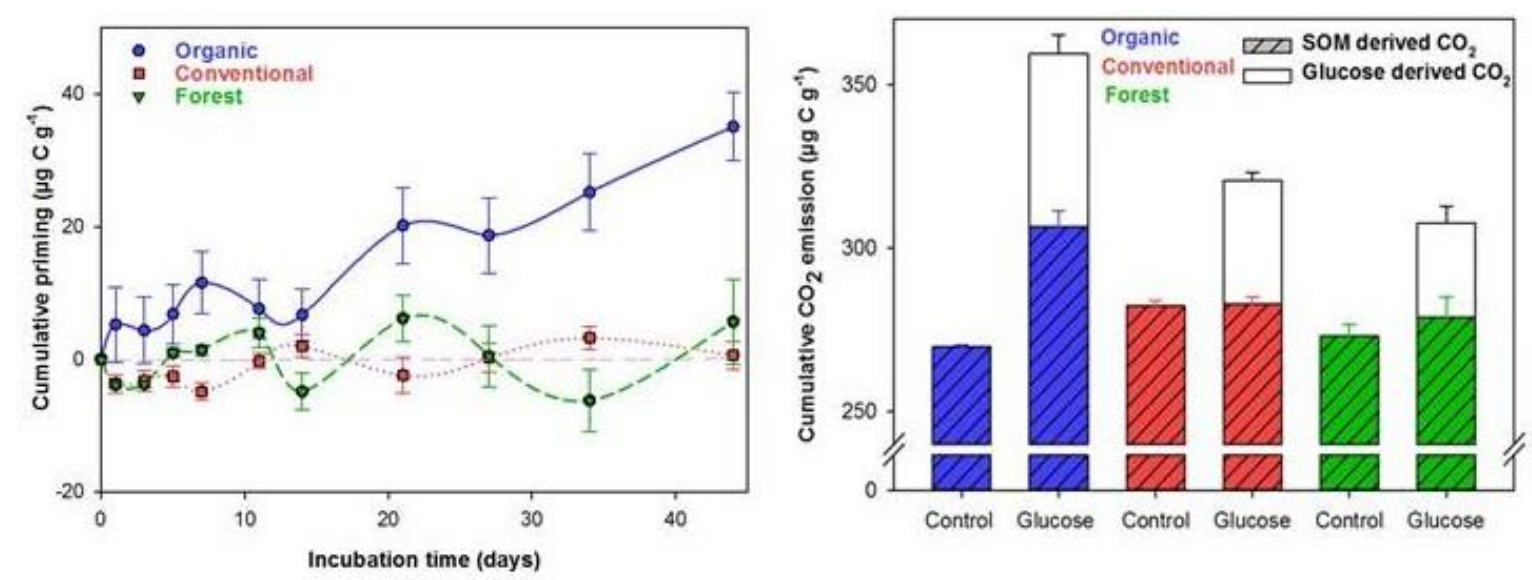

Figure 1 Cumulative priming over 45 days of incubation period and cumulative $\mathrm{CO}_{2}$ emission at 45 days in soil under organic farming, conventional farming, and forest. Values are means \pm standard error $(n=4)$.

\subsubsection{Microbial biomass}

Strong reductions in SOM-derived microbial biomass C (by 24\%) were observed in Camended soils compared to control under organic farming (Fig. 2). However, there was no significant effect of $\mathrm{C}$ addition in SOM-derived $\mathrm{MBC}$ in soils under conventional farming and forest. The incorporation of ${ }^{14} \mathrm{C}$ was higher in soils under organic farming and conventional farming than in forest. 


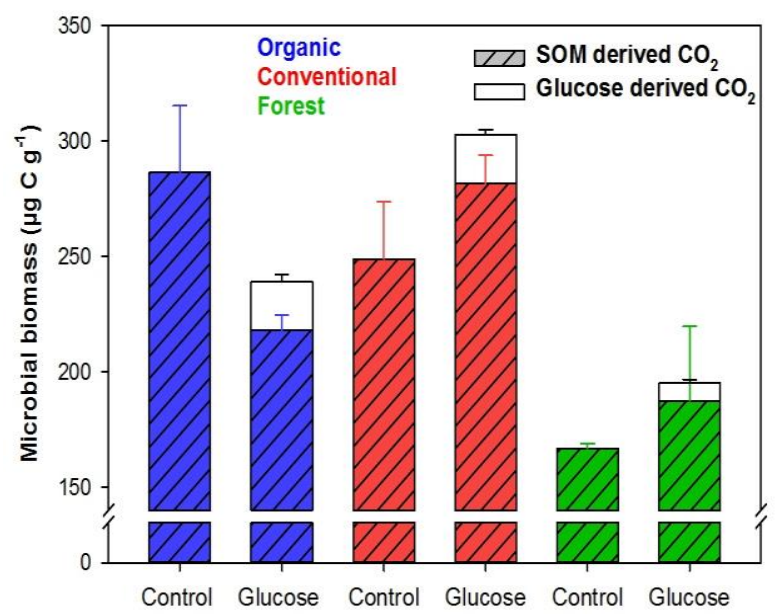

Figure 2 Microbial biomass at 45 days in soil under organic farming, conventional farming, and forest. Values are means \pm standard error $(n=4)$.

\subsubsection{Microbial growth parameters}

Addition of glucose and nutrients to determine microbial growth parameters induced an exponential increase in $\mathrm{CO}_{2}$ emission rates in all land use systems (Fig.3). The increase in soil respiration rate occurred earlier in organic farming soil compared to the other land use systems. Thus, the lag period gradually increased and was the shortest in organic farming $(5 \mathrm{~h})$ as compared to conventional farming ( $15 \mathrm{~h}$ ) and forest ( $25 \mathrm{~h})$ (Fig. 3). AMB was lower in soil under forest $(0.4 \%$ of $\mathrm{TMB})$ than organic farming $(1.0 \%)$ and conventional farming $(1.4 \%, p<0.05)$. Maximum specific growth rate was higher $\left(0.48 \mathrm{~h}^{-1}\right)$ in soil under organic farming followed by conventional farming $\left(0.14 \mathrm{~h}^{-1}\right)$ and forest $\left(0.13 \mathrm{~h}^{-1}\right)$ (Fig. 3). The high $\mu \mathrm{m}$ showed relative dominance of $r$-strategists in organic farming. Overall, the addition of substrates activated different microbial community functional groups in different land use systems.
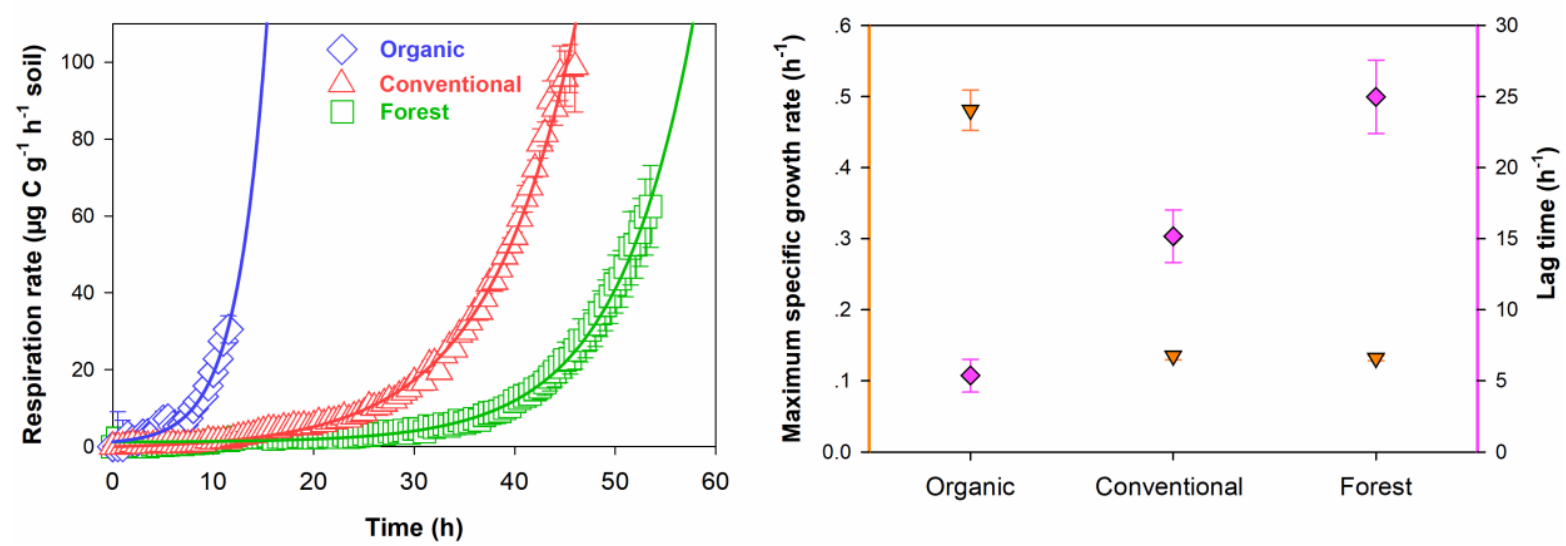

Figure 3 Substrate-induced respiration rates, maximum specific growth rate and lag time in soil under different land use system. Values are means \pm standard error $(n=3)$. 


\subsubsection{Discussion}

\subsubsection{Mechanisms of priming effect in relation to microbial-necromass and growth strategists}

The increase in priming-derived $\mathrm{CO}_{2}$ was accompanied by $\mathrm{MBC}$ reductions of $24 \%$ in organic soil at 45 days (Fig. 1 and 2). However, this response was absent in soil under conventional farming and forest. This raises the questions "which group(s) of microorganisms is contributing to this mechanism" and "why do they contribute?" This enigma can answered using common ecological principles of microbial life strategists. Here, we unify the concept of $\mathrm{r}-\mathrm{K}$ selection with the common ecology concept for describing the life history pattern of soil microorganisms (Fierer et al., 2007). Microbial growth rate was significantly higher in organic farm soils corresponding with a greater $\mu \mathrm{m}\left(0.48 \mathrm{~h}^{-1}\right.$, Fig. 3 ), demonstrating the dominancy of $r$ - strategists in these soils. Furthermore, the short lag time (5h, Fig. 3) in organic soils indicated that microorganisms vigorously activated with added substrate, resulting in early starvation. Under such circumstances, microorganisms will change their strategy to cope with unfavorable conditions. Thus, $r$-strategists induce autolysis to reducing their biomass, as they can grow faster whenever the situation again becomes favorable. This autolysis leads to the formation of microbial cell necromass (Miltner et al., 2009; Miltner et al., 2012). Interestingly, the amount of primed $\mathrm{CO}_{2}(37 \mu \mathrm{g} \mathrm{C}$ $\left.\mathrm{g}^{-1}\right)$ was comparable to the reduction in microbial biomass $\left(47 \mathrm{\mu g} \mathrm{C} \mathrm{g}^{-1}\right)$ at the later stage of incubation. It is reasonable that the surviving microorganisms utilized necromass as source of substrates (Shabaz et al 2017). Consequently, activated microorganisms decompose native SOM to fulfill their metabolic requirements, leading to increased decomposition of SOM, i.e., positive priming.

Although specific growth rates were similar in conventional and forest soils, the growth curve patterns were different (Fig. 3). This disparity can be related to the difference in lag time (25 h vs $15 \mathrm{~h}$ in soil under forest and conventional farming, respectively). This disparity indicates the dominance of two different kinds of strategists. Short lag time with high AMB (1.4\%) in soil under conventional farming indicates the occurrence of $\mathrm{K}$ strategists, possessing the tendencies of slow growth but faster recovery, while long lag time and low AMB $(0.4 \%)$ gives strong evidence of the existence of L-strategists in soil under forest, having high tolerance capacities and slow recovery under stressful environments. K-strategists undergo dormancy to cope with starvation conditions. Thus, no mining of SOM, and consequently no PE, occurs in conventional farming soils (Fig. 4). 
However, L-strategists remain stable, as they can tolerate stress. Due to limited resources, these microorganisms are slightly able to mine SOM, resulting in fluctuating PE in forest soils (Fig. 4). These results support our hypothesis that soils dominated by fast-growing microorganisms have reductions in microbial biomass under starvation conditions, leading to increases in PE in soil under organic farming.

\subsubsection{Priming in relation to soil quality}

Soil under three land use systems i.e. forest, organic and conventional farming comprise diverse soil and microbial properties i.e. C, N, P microbial biomass, and enzyme activities (Table 1, Maharjan et al., 2017). Each land use holds specific management practices. Consequently, those land use and management practices controls soil quality i.e. soil and microbial properties. Organic management i.e. application of farmyard manure, vermicompost, crop residue incorporation, and cropping system significantly increase SOM; supporting higher microbial biomass. Thus, soil under organic farming consider as rich soil due to high concentration of soil and microbial properties. However, frequent tillage with less incorporation of residue, application of pesticides and chemical fertilizer significantly reduce the SOM, regarded as medium soil. Litter removal including low canopy cover and regeneration results the lowest soil and microbial properties in forest, reflecting as poor soil. It is evident that soil quality affects microbial growths strategies. Rich soil (organic farming) comprises r-strategies while medium soil (conventional farming) holds $\mathrm{K}$ strategies and L-strategies in poor soil (forest). Consequently, microbial growth strategies determine PE in soil under different land use systems. Thus it is logical to say that soil quality is driver of PE in natural ecosystem (Fig. 4) 


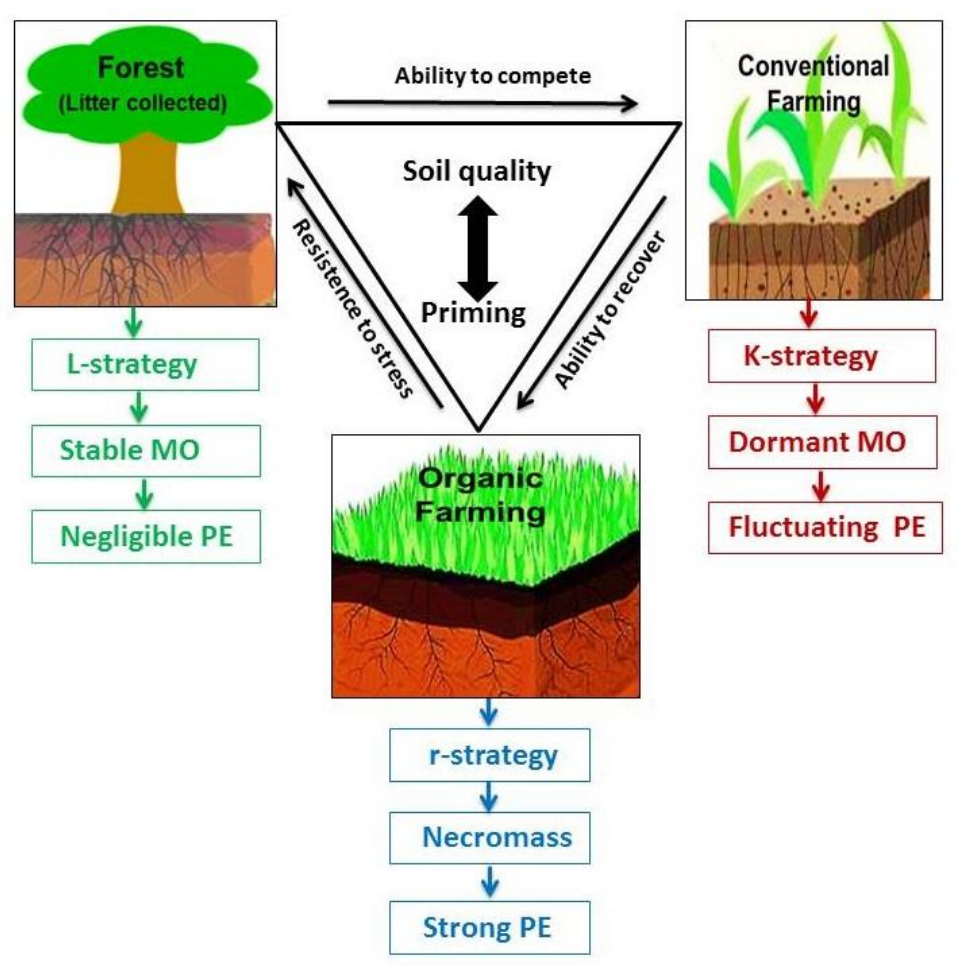

Figure 4 Conceptual diagram representing the three types of life strategies corresponding to three types land use system (Panikov, 2010). PE-priming effect and MO-microorganism

\subsubsection{Conclusion}

Higher specific growth rates and short lag times revealed the dominancy of $r$-strategists in rich soils under organic farming. Due to starvation during incubation, $r$ - strategists form necromass through autolysis. Consequently, the remaining microorganisms were activated after utilizing the necromass as a substrate source, increasing the decomposition of SOM to fulfill their metabolic requirements. Thus, positive priming with decreasing microbial biomass was observed in soil under organic farming. The short lag time with high active microbial biomass percentage in medium soil under conventional farming showed the dominancy of K-strategists. While the long lag time and lowest active microbial biomass percentage gives strong evidence for the existence of L-strategists in poor soil under forest. K-strategists undergo to dormancy while L-strategists remain stable under starvation conditions, resulting in no to fluctuating PE in soil under conventional farming and forest, respectively. All in all, PE is determined by the dominant growth strategy present in soil microbial communities, which is influenced by soil quality, revealing soil quality as the driver of PE. 


\subsubsection{Acknowledgements}

We acknowledge the Erasmus mundus (Experst4Asia) for financial support of Menuka Maharjan and Chinese Academy of Science (CAS) for Huadong Zang. The authors would like to thank Karin Schmidt and Anita Kriegel for laboratory assistance, and Sandesh Bhatta and Bibek Thapa for field work assistance.

\subsubsection{Reference}

Anderson, J.P.E., Domsch, K.H., 1978. A physiological method for the quantitative measurement of microbial biomass in soils. Soil Biol. Biochem. 10, 215-221. https://doi.org/10.1016/00380717(78)90099-8

Bellamy, P.H., Loveland, P.J., Bradley, R.I., Lark, R.M., Kirk, G.J.D., 2005. Carbon losses from all soils across England and Wales 1978-2003. Nature 437, 245-248. https://doi.org/10.1038/nature04038

Blagodatskaya, E., Kuzyakov, Y., 2008. Mechanisms of real and apparent priming effects and their dependence on soil microbial biomass and community structure: Critical review. Biol. Fertil. Soils 45, 115-131. https://doi.org/10.1007/s00374-008-0334-y

Blagodatskaya, E.V., Blagodatsky, S.A., Anderson, T.-H., Kuzyakov, Y., 2007. Priming effects in Chernozem induced by glucose and $\mathrm{N}$ in relation to microbial growth strategies. Appl. Soil Ecol. 37, 95-105. https://doi.org/10.1016/j.apsoil.2007.05.002

Blagodatsky, S.A., Heinemeyer, O., Richter, J., 2000. Estimating the active and total soil microbial biomass by kinetic respiration analysis. Biol. Fertil. Soils 32, 73-81. https://doi.org/10.1007/s003740000219

Chen, R., Senbayram, M., Blagodatsky, S., Myachina, O., Dittert, K., Lin, X., Blagodatskaya, E., Kuzyakov, $\mathrm{Y}$., 2014. Soil $\mathrm{C}$ and $\mathrm{N}$ availability determine the priming effect: Microbial $\mathrm{N}$ mining and stoichiometric decomposition theories. Glob. Chang. Biol. 20, 2356-2367. https://doi.org/10.1111/gcb.12475

Chen, S., Wang, Y., Hu, Z., Gao, H., 2015. CO<inf $>2</$ inf $>$ emissions from a forest soil as influenced by amendments of different crop straws: Implications for priming effects. Catena 131, 56-63. https://doi.org/10.1016/j.catena.2015.03.016

Coleman, D.C., Crossley, D.A., Hendrix, P.F., 2004. Fundamentals of Soil Ecology, second ed. ed. Elsevier Inc.

De Nobili, M., Contin, M., Mondini, C., Brookes, P.C., 2001. Soil microbial biomass is triggered into activity by trace amounts of substrate. Soil Biol. Biochem. 33, 1163-1170. https://doi.org/10.1016/S0038-0717(01)00020-7

Dijkstra, F.A., Cheng, W., Johnson, D.W., 2006. Plant biomass influences rhizosphere priming effects on soil organic matter decomposition in two differently managed soils. Soil Biol. Biochem. 38, 2519-2526. https://doi.org/10.1016/j.soilbio.2006.02.020

Fierer, N., Bradford, M.A., Jackson, R.B., 2007. TOWARD AN ECOLOGICAL CLASSIFICATION OF SOIL BACTERIA. Ecology 88, 1354-1364. https://doi.org/10.1890/05-1839

Fontaine, S., Mariotti, A., Abbadie, L., 2003. The priming effect of organic matter: A question of microbial competition? Soil Biol. Biochem. 35, 837-843.

Gilmullina, A., Blagodatskaya, E.V., Kuzyakov, Y., 2017. Protocol to soil respiration measurement by RABIT. Soil Science Department, University of Goettingen, Germany.

Heaton, L., Obara, B., Grau, V., Jones, N., Nakagaki, T., Boddy, L., Fricker, M.D., 2012. Analysis of fungal networks. Fungal Biol. Rev. 26, 12-29. https://doi.org/10.1016/j.fbr.2012.02.001

Hoang, D.T.T., Pausch, J., Razavi, B.S., Kuzyakova, I., Banfield, C.C., Kuzyakov, Y., 2016. Hotspots of microbial activity induced by earthworm burrows, old root channels, and their combination in subsoil. Biol. Fertil. Soils. https://doi.org/10.1007/s00374-016-1148-y

IUSS Working Group WRB, 2015. World Reference Base for Soil Resources for 2014. World Soil Resources Report No. 106. FAO, Rome, 203 pp.

Jobbágy, E.G., Jackson, R.B., 2000. The vertical distribution of soil organic carbon and its relation to climate and vegetation. Ecol. Appl. 10, 423-436. https://doi.org/10.1890/10510761(2000)010[0423:TVDOSO]2.0.CO;2 
Kirkby, C.A., Richardson, A.E., Wade, L.J., Batten, G.D., Blanchard, C., Kirkegaard, J.A., 2013. Carbon-nutrient stoichiometry to increase soil carbon sequestration. Soil Biol. Biochem. 60, 77-86. https://doi.org/10.1016/j.soilbio.2013.01.011

Maharjan, M., Sanaullah, M., Razavi, B.S., Kuzyakov, Y., 2017. Effect of land use and management practices on microbial biomass and enzyme activities in subtropical top-and sub-soils. Appl. Soil Ecol. 113, 22-28. https://doi.org/10.1016/j.apsoil.2017.01.008

Mau, R.L., Liu, C.M., Aziz, M., Schwartz, E., Dijkstra, P., Marks, J.C., Price, L.B., Keim, P., Hungate, B.A., 2015. Linking soil bacterial biodiversity and soil carbon stability. ISME J. 9, 1477-1480. https://doi.org/10.1038/ismej.2014.205

Miltner, A., Bombach, P., Schmidt-Brücken, B., Kästner, M., 2012. SOM genesis: Microbial biomass as a significant source. Biogeochemistry 111, 41-55. https://doi.org/10.1007/s10533-0119658-z

Miltner, A., Kindler, R., Knicker, H., Richnow, H., Kästner, M., 2009. Organic Geochemistry Fate of microbial biomass-derived amino acids in soil and their contribution to soil organic matter. Org. Geochem. 40, 978-985. https://doi.org/10.1016/j.orggeochem.2009.06.008

Panikov, N.S., 1995. Microbial Growth Kinetics, In: Glasgo. ed. Chapman and Hall, London.

Panikov, N.S., Sizova, M. V., 1996. A kinetic method for estimating the biomass of microbial functional groups in soil. J. Microbiol. Methods 24, 219-230.

Panikov, N.S., 2010. Microbial Ecology. In: Wang L., Ivanov V., Tay JH. (Eds), Environmental Biotechnology . Handbook of Environmental Engineering. vol 10.Humana Press, Totowa, NJ.

Pianka, E.R., 1970. On r- and K-selection. Am. Nat. 104, 592-597.

Schlesinger, W.H., 1977. Carbon Balance in terrestrial detritus. Annu. Rev. Ecol. Syst. 8, 51-81.

Shahbaz, M., Kuzyakov, Y., Sanaullah, M., Heitkamp, F., Zelenev, V., Kumar, A., Blagodatskaya, E., 2017. Microbial decomposition of soil organic matter is mediated by quality and quantity of crop residues: mechanisms and thresholds. Biol. Fertil. Soils 1-15. https://doi.org/10.1007/s00374-016-1174-9

Swift, M.J., Heal, O.W., Anderson, J.M., 1979. Decomposition in Terrestrial Ecosystems,. Blackwell, Oxford.

Vance, E.D., Brookes, P.C., Jenkinson, D.S., 1987. An extraction method for measuring soil microbial biomass C. Soil Biol. Biochem. 19, 703-707. https://doi.org/10.1016/00380717(87)90052-6

Wagner GH, 1968. Significance of microbial tissue to soil organicmatter. Vienna. 


\title{
4.1 Study 5: Spatio-temporal patterns of enzyme activities after manure application reflect mechanisms of niche differentiation between plants and microorganisms
}

\author{
Shibin Liu $a^{1, *}$, Bahar S. Razavi $b^{2}, \mathrm{Xu} \mathrm{Su}^{3}$, Menuka Maharjan ${ }^{2}$, \\ Mohsen Zarebanadkouki ${ }^{4}$, Evgenia Blagodatskaya ${ }^{1}$, Yakov Kuzyakov ${ }^{1,2,5}$ \\ Status: Published online in Soil Biology and Biochemistry
}

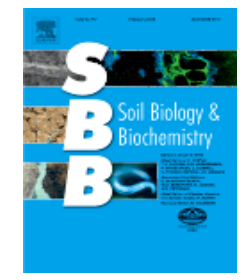

${ }^{1}$ Department of Soil Science of Temperate Ecosystems, University of Göttingen, Germany

2 Department of Agricultural Soil Science, University of Göttingen, Göttingen, Germany

${ }^{3}$ Key Laboratory of Education Ministry on Environments and Resources in Tibetan Plateau, Xining, China

${ }^{4}$ Division of Soil Hydrology, University of Göttingen, Germany

${ }^{5}$ Huazhong Agriculture University, Wuhan, China

\subsubsection{Abstract}

Manure is an important source of nutrients for plants and stimulates a wide range of enzyme-mediated microbial processes. Such stimulation, however, depends on manure distribution and the duration of its decomposition in soil. For the first time, we investigated the spatio-temporal patterns of enzyme activities as affected by manure application strategies:1) Localized manure: manure application as a layer in the upper soil; 2) Homogenized manure: mixing manure throughout the soil; and 3) Control without manure. Tibetan barley was planted on soil managed with yak manure from the Tibetan Plateau. Soil zymography was used to visualize the two-dimensional distribution and dynamics of the activities of three enzymes responsible for cycling of carbon ( $\beta$-glucosidase), nitrogen ( $\mathrm{N}$ acetylglucosaminidase) and phosphorus (phosphomonoesterase) over 45 days. The manure detritusphere increased enzyme activities relative to the control (which had only the rhizosphere effect of barley) and this stimulation lasted less than 45 days. Enzyme activities in the manure-induced hotspots were higher than on the barley rhizoplane, indicating that the detritusphere stimulated microbial activities more strongly than roots. Homogenized manure led to $3-29 \%$ higher enzyme activities than localized manure, but shoot and root biomass was respectively 3.1 and 6.7 times higher with localized manure application. Nutrients released by high enzyme activities within the whole soil volume will be efficiently trapped by microorganisms. In contrast, nutrients released from manure 
locally are in excess for microbial uptake and remain available for roots. Consequently, microorganisms were successful competitors for nutrients from homogeneous manure application, while plants benefited more from localized manure application. We conclude that localized manure application decreases competition for nutrients between the microbial community of manure and the roots, and thereby increases plant performance.

Keywords: Manure application strategies, direct zymography, Tibetan Plateau, enzyme activity visualization, Barley roots, Hordeum vulgare 


\subsection{Study 6: Effects of rhizosphere wettability on microbial biomass, enzyme activities and localization}

Katayoun Ahmadi ${ }^{1,2^{*}}$, Bahar S. Razavi ${ }^{1}$, Menuka Maharjan ${ }^{3}$,Yakov Kuzyakov ${ }^{1,4,7}$, Stanley J. Kostka ${ }^{5}$, Andrea Carminati ${ }^{6}$, Mohsen Zarebanadkouki ${ }^{6}$

Status: Submitted to Biology and Fertility of Soils

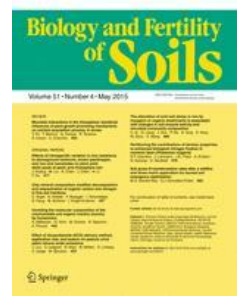

${ }^{2}$ Department of Horticulture, Ministry of Agriculture Jihad, Tehran, Iran

${ }^{3}$ Department of Soil Science of Temperate Ecosystems, University of Goettingen, Goettingen, Germany

${ }^{4}$ Institute of Environmental Sciences, Kazan Federal University, 420049 Kazan, Russia

${ }^{5}$ Aquatrols Corporation of America, Paulsboro, New Jersey USA

${ }^{6}$ Division of Soil Physics, University of Bayreuth, 95450 Bayreuth, Germany

${ }^{7}$ Agro-Technology Institute, RUDN University, Moscow, Russia

\subsubsection{Abstract}

Drying and wetting cycles of the rhizosphere compared to the bulk soil impact microbial and enzymes activities. For instance, the rhizosphere of some plant species (e.g. Zea Mays L. or Lupinus Albus L.) becomes water repellent upon drying and this may limit microbial activity during repeated drying and wetting events. The objective of this study was to investigate the effects of rhizosphere water repellency on distribution and localization of enzyme activities. We hypothesized that an increase of rhizosphere wettability by a polymeric surfactant (here referred to as rhizoligand) raises enzyme activities, especially during repeated drying/rewetting cycles. Maize plants were grown in rhizoboxes and subjected to six drying/rewetting cycles for eight weeks. Half of the plants were irrigated with water and the other half with rhizoligand solution. After six drying/rewetting cycles, we measured: i) enzyme activities and distribution using zymography; ii) microbial biomass carbon; and iii) shoot and root biomass. Application of a rhizoligand: i) increased the $\beta$ glucosidase and phosphatase activities by 5.3 and 2.9 times, respectively, in the regions close to the roots (0-0.5 $\mathrm{mm}$ distance from the root surface); ii) enlarged the area with high enzyme activity 1.46-fold for $\beta$-glucosidase and 1.2-fold for phosphatase; iii) increased microbial biomass content 1.57-fold; and iv) increased root biomass 1.24-fold. This general 
stimulation of microbial activity is connected with the increase in rhizosphere wettability upon rhizoligand application. The higher wettability maintains the stability of microbial habitats and stimulates enzyme activities in the rhizosphere during repeated drying/wetting cycles. We propose that such biophysical rhizosphere interactions could open new avenues to improve plant performance in water deficit condition by rhizoligand application were determined following chloroform-fumigation method (Hedley et al., 1982). Phosphatase activity was determined in-situ by Zymography.

Keywords: Microbial activity, enzyme activity, soil water repellency, rhizoligand, rhizosphere process, polymeric surfactant 


\subsection{Curriculum vitae}

Name: Menuka Maharjan

Date of Birth: July1, 1984

Place of Birth: Kathmandu, Nepal
E-mailmenuka48maharjan@gmail.com

Tel: +491628296907

Nationality: Nepalese

\section{Education Career}

2014 - 2018:

Ph.D. student, Georg-August-University of Göttingen, Germany

$2007-2009$

Master of Science in Watershed Management, Institute of Forestry, Tribhuwan University, Nepal

2003 - 2006:

Bachelor of Science in Environmental Science, Trichandra Multiple Campus, Tribhuwan University, Nepal

1988 - 2002:

High school period, Government of Nepal, Nepal

\section{Professional Experiences}

2012 - Present

2011

2011

\section{Awards and grants}

$2014-2017$

2016

2013

2012

2009

2008
Lecturer; Institute of Forestry, Tribhuwan University, Nepal

Consultant, Climate Management Division, Ministry of Environment, Nepal

Researcher in by Deutsche Gesellschaft für Internationale Zusammenarbeit (GIZ), Nepal

Recipient, Experts4Asia Erasmus mundus PhD scholarship, European Union

Recipient, American Geophysical Union (AGU), Fall meeting grant, USA

Recipient, Experts4Asia Erasmus mundus; Staff mobility scholarship, European Union

Recipient, ITEC fellowship, Ministry of External Affair, India

Research grant, Annapurna Conservation Area Project (ACAP), Nepal

Partial Fellowship, Master degree completion, NUFU, Norway 


\section{Expertise}

Soil fertility, Land use, watershed management, Environmental management Nutrient cycling,

\section{Publications}

- Maharjan, M.*, Sanaullah, M., Razavi, B.S., Kuzyakov, Y., 2017. Effect of land use and management practices on microbial biomass and enzyme activities in subtropical top-and sub-soils. Applied Soil Ecology, doi:10.1016/j.apsoil.2017.01.008

- Maharjan, M.*, Maranguit, D., Kuzyakov, Y., 2017. Phosphorus fractions in subtropical soils depending on land use. European Journal of Soil Biology (under review)

- Liu, S. *, Razavi B.S., Su, X., Maharian, M., Zarebanadkouki, M., Blagodatskaya, E., Kuzyakov, Y., 2017. Spatio-temporal patterns of enzyme activities after manure application reflect mechanisms of niche differentiation between plants and microorganisms. Soil Biology \& Biochemistry,

- Maharjan, $\mathrm{M}_{.}{ }_{2}$ Awasthi, K.D., Pande K.R., Thapa, N., 2014. Nutrient status of rangeland in upper Mustang. Ban Ko Jankari, vol 24, no 1.

- Ahmadi, K.*, Razavi, B.S., Maharjan, M., Kuzyakov, Y., Kostka, S.J., Carminati, A., Zarebanadkouki, M., 2017. Effect of rhizosphere wettability on microbial biomass, enzyme activities, and localization. Biology and Fertility of Soils (submitted)

\section{Conference Papers}

- $6^{\text {th }}$ International Symposium on Soil Organic Matter 2017, UK: "Nutrient Availability Regulates Soil Organic Matter Decomposition Depending on Land Use": Maharjan M., Zang H., Blagodatskaya E., Kuzyakov Y. Poster presentation.

- American Geophysical Union (AGU) 2016, USA: "Microbial Indicators of Soil Quality under Different Land Use Systems in Subtropical Soils". Maharjan M., Kuzyakov Y. Poster presentation

- European Geosciences Union (EGU) 2016, Austria. "Effect of land use on microbial biomass and enzyme activities in subtropical soil". Maharjan, M., Sanaullah, M., Razavi, B.S., Kuzyakov, Y. Oral presentation

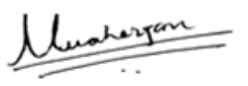

(Signature) $24^{\text {th }}$ March, 2018

(Date) 


\subsection{Declarations}

1. I, hereby, declare that this Ph.D. dissertation has not been presented to any other examining body either in its present or a similar form.

Furthermore, I also affirm that I have not applied for a Ph.D. at any other higher school of education.

Göttingen,

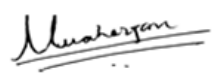

(Signature)

2. I, hereby, solemnly declare that this dissertation was undertaken independently and without any unauthorized aid.

Göttingen,

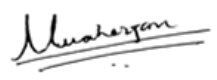

(Signature) 